\title{
CONTROLE DE PERDAS NA ENSILAGEM DE CAPIM TANZÂNIA (Panicum maximum Jacq. cv. Tanzânia) SOB OS EFEITOS DO TEOR DE MATÉRIA SECA, DO TAMANHO DE PARTÍCULA, DA ESTAÇÃO DO ANO E DA PRESENÇA DO INOCULANTE BACTERIANO
}

\author{
MAURICIO SCOTON IGARASI
}

Dissertação apresentada à Escola Superior de Agricultura "Luiz de Queiroz", Universidade de São Paulo, para obtenção do título de Mestre em Agronomia, Área de Concentração: Ciência Animal e Pastagens.

\section{PIRACICABA}

Estado de São Paulo - Brasil

Janeiro - 2002 


\title{
CONTROLE DE PERDAS NA ENSILAGEM DE CAPIM TANZÂNIA (Panicum maximum Jacq. cv. Tanzânia) SOB OS EFEITOS DO TEOR DE MATÉRIA SECA, DO TAMANHO DE PARTÍCULA, DA ESTAÇÃO DO ANO E DA PRESENÇA DO INOCULANTE BACTERIANO
}

\section{MAURICIO SCOTON IGARASI}

\author{
Zootecnista
}

Orientador: Prof. Dr. LUIZ GUSTAVO NUSSIO

\begin{abstract}
Dissertação apresentada à Escola Superior de Agricultura "Luiz de Queiroz", Universidade de São Paulo, para obtenção do título de Mestre em Agronomia, Área de Concentração: Ciência Animal e Pastagens.
\end{abstract}

\section{PIRACICABA}

Estado de São Paulo - Brasil

Janeiro - 2002 
Dados Internacionais de Catalogação na Publicação (CIP) DIVISÃO DE BIBLIOTECA E DOCUMENTAÇÃO - ESALQ/USP

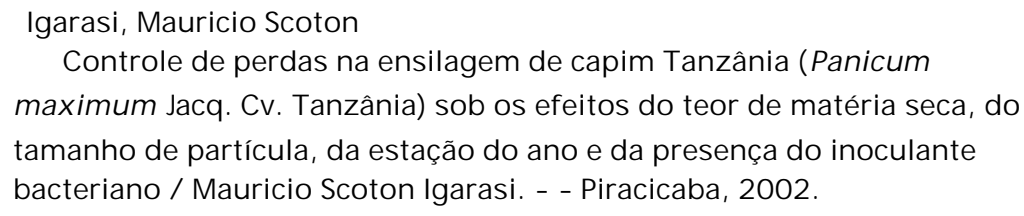

Dissertação (mestrado) - - Escola Superior de Agricultura Luiz de Queiroz, 2002.

Bibliografia.

1. Capim colonião 2. Ensilagem 3. Perdas agrícolas 4. Valor nutritivo I. Título

CDD 636.08552

"Permitida a cópia total ou parcial deste documento, desde que citada a fonte - $\mathrm{O}$ autor" 


\section{Agradeço,}

Meu orientador Prof. Luiz Gustavo Nussio, pelos ensinamentos, convívio e exemplo de profissionalismo e amor a profissão,

Os amigos e companheiros do grupo de trabalho e pesquisa, Dani, Soli, Lucas, Rodrigo e André, por toda a colaboração no presente trabalho, e amizade nas horas de descontração,

À CAPES, pela bolsa de estudo concedida,

Os amigos e professores do GEPF, pela concessão de uso de suas instalações e equipamentos, em especial ao Prof. Sila Carneiro da Silva, pela também ajuda na análise estatísitca,

O LPA - Setor de Ruminantes, em especial o funcionário José Benedito de Oliveira, por sua colaboração indispensável,

A SILTOMAC Ltda, pela parceria no experimento,

A empresa fornecedora do aditivo bacteriano $E C O S Y L^{\circledR}$,

O Prof. Alexandre Vaz Pires, pela orientação inicial,

A Boviplan Cons. Agropecuária, o Agr. José Arlindo Marques, e todas as fazendas que colaboraram no levantamento de índices técnicos de silagem,

Todos demais que tiveram participação direta ou indireta na realização desse trabalho,

A Deus, 
Dedico,

A minha mãe Sebastiana, meu pai Roberto (in memorian) e irmã Yae,

À toda minha família,

A todos os amigos e professores da ESALQ, por esses 2 anos de amizade e convivência,

Ao Prof. Vidal Pedroso de Faria e sua família, pela confiança depositada,

A Agro-Pecuária CFM Ltda, em especial ao amigo Elisário Cleto de Oliveira, pelos ensinamentos de zootecnia e principalmente de vida,

Meu muito obrigado. 


\section{SUMÁRIO}

Pagina

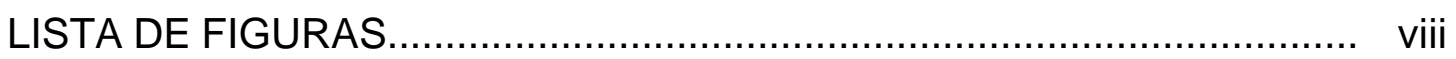

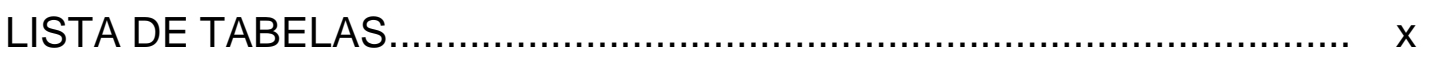

LISTA DE ABREVIATURAS.......................................................... xiii

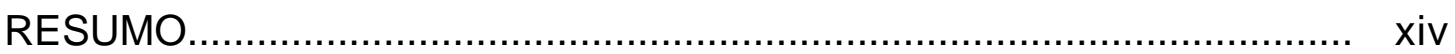

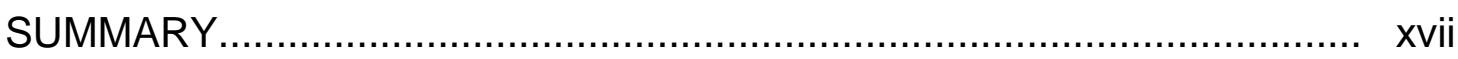

1 INTRODUÇÃO

2 REVISÃO DE LITERATURA..................................................... 4

2.1 Potencial da ensilagem de capins tropicais........................................ 4

2.2 Teor de matéria seca................................................................. 9

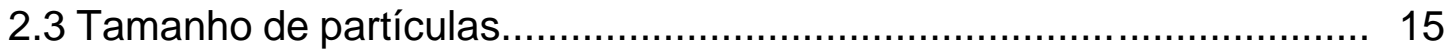

2.4 Perdas por gases e efluentes ..................................................... 17

2.5 Inoculante bacteriano................................................................. 19

2.6 Estabilidade sob aerobiose .......................................................... 22

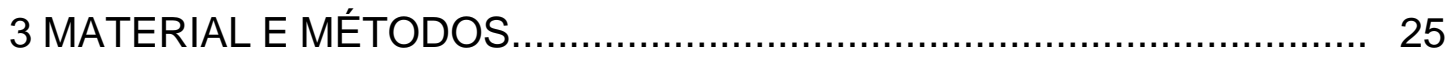

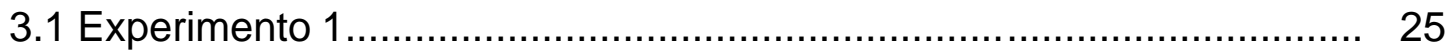

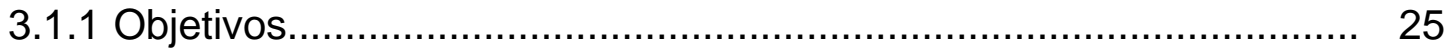

3.1.2 Material e Métodos................................................................. 25

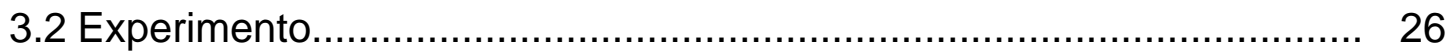

3.2.1 Corte, colheita e picagem........................................................ 28

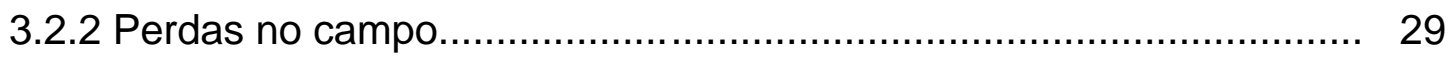

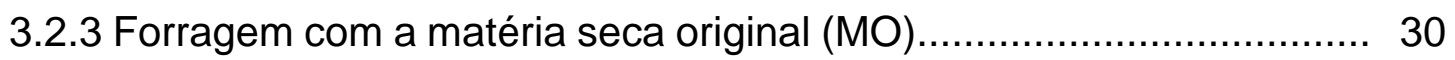


3.2.4 Pré-emurchecimento............................................................. 30

3.2.5 Adição de polpa cítrica peletizada (PCP) ...................................... 31

3.2.6 Aplicação do inoculante bacteriano................................................ 31

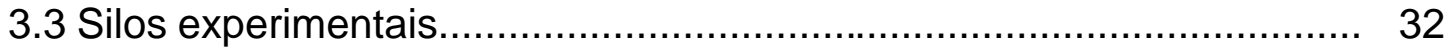

3.4 Abertura dos silos experimentais.................................................. 33

3.5 Análises realizadas.................................................................. 34

3.5.1 Atividade de água (AW) ........................................................ 34

3.5.2 Condutividade elétrica (CE) ...................................................... 34

3.5.3 Poder Tampão e pH............................................................... 34

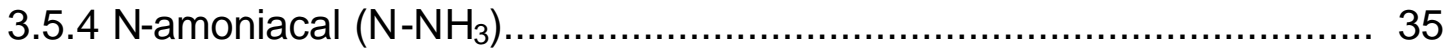

3.5.5 Bromatologia (MS, MM, PB, EE, FDN, FDA, N-FDN, N-FDA,

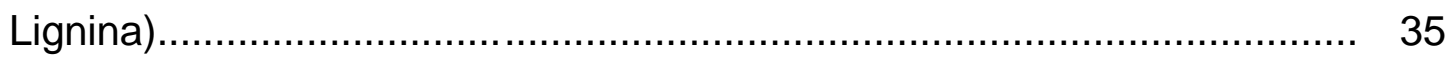

3.5.6 Granulometria das partículas................................................. 35

3.5.7 Estabilidade aeróbica............................................................ 36

3.5.8 Cálculo da energia da silagem.................................................. 36

3.6 Análise estatística.................................................................... 37

4 RESULTADOS E DISCUSSÃO......................................................... 38

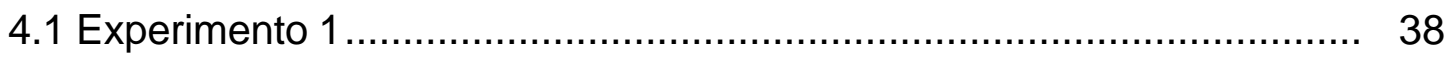

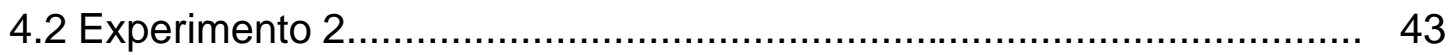

4.2.1 Composição bromatológica da forragem na ensilagem..................... 43

4.2.2 Atividade de água (AW) ......................................................... 49

4.2.3 Tamanho de partículas e densidade................................................. 50

4.2.4 Condutividade elétrica................................................................. 52

4.2.5 Perdas por Efluente............................................................. 57

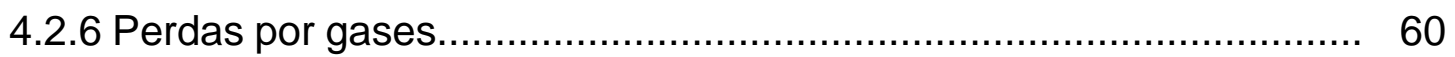

4.2.7 Estabilidade aeróbica.............................................................. 64

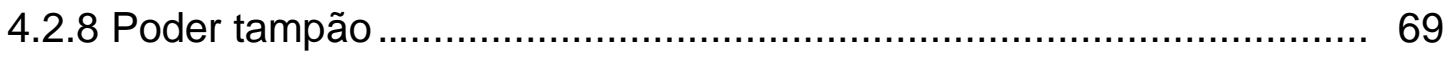

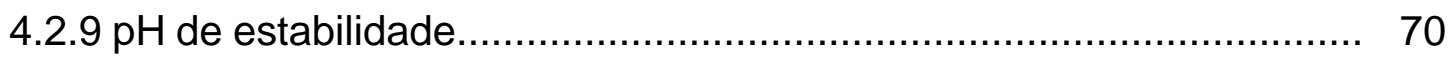

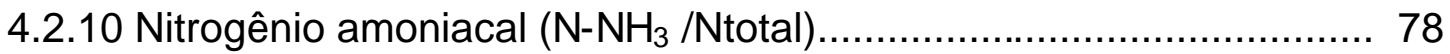

4.2.11 Fração B3......................................................................... 83 
4.2.12 Fibra insolúvel em detergente neutro (FDN) .............................. 86

4.2.13 Fibra insolúvel em detergente ácido (FDA) ................................. 89

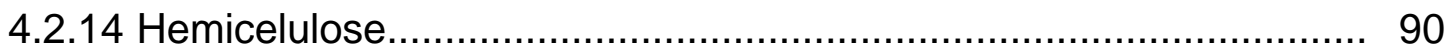

4.2.15 Nutrientes Digestíveis Totais (NDT) .......................................... 93

4.2.16 Cálculo de custos do NDT......................................................... 99

5 CONCLUSÕES....................................................................... 102

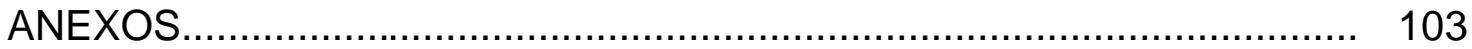

REFERÊNCIAS BIBLIOGRÁFICAS................................................. 113 


\section{LISTA DE FIGURAS}

Página

1 Distribuição das propriedades visitadas em relação ao valor de $\mathrm{pH}$ das silagens de capim.

2 Distribuição das propriedades visitadas em relação ao valor da densidade $\left(\mathrm{tMS}^{-3} \mathrm{~m}^{-3}\right)$ das silagens de capim......................................

3 Representação gráfica da distribuição da condutividade elétrica (ì S. $\mathrm{cm}^{-2}$ ), em função do tamanho de partícula (\% retida na peneira de $1,905 \mathrm{~cm})$, das silagens de gramíneas coletadas nas propriedades.

4 Relação entre e a densidade da silagem $\left(\mathrm{kgMS} \cdot \mathrm{m}^{-3}\right)$, o tamanho de partícula (\% MS retida na peneira de $1,905 \mathrm{~cm}$ ) das silagens de gramíneas coletadas nas visitas técnicas

5 Efeito do tamanho de partícula na densidade $\left(\mathrm{kg}\right.$ de silagem. $\left.\mathrm{m}^{3}\right)$, em silagem de capim Tanzânia.

6 Efeito do teor de matéria seca em relação a densidade ( $\mathrm{kg}$ de MS. $\mathrm{m}^{-3}$ ) da silagem de capim Tanzânia. 7 Porcentagem de retenção de matéria seca na peneira de $1,905 \mathrm{~cm}$ de diâmetro, nas silagens de capim Tanzânia ensiladas com a umidade original $(\mathrm{MO})$, pré-emurchecidas ou recebendo adição de polpa cítrica (MOPC), nos tamanhos de partícula maior (PMa) e menor (PMe), nos cortes de verão e inverno. 
8 Relação entre a porcentagem do material retido na peneira de $1,905 \mathrm{~cm}$ de diâmetro, em função da condutividade elétrica (CE,

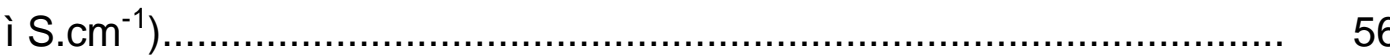

9 Equação de Haigh (1999) na determinação da produção de efluente $\left(\mathrm{L} . \mathrm{t}^{-1}\right)$ em relação ao teor de matéria seca $\left(\mathrm{g} . \mathrm{kg}^{-1}\right)$................. 57 10 Equação para estimativa da produção de efluente $\left(\mathrm{kg} \cdot \mathrm{t}^{-1}\right.$ de forragem fresca) em relação ao teor de matéria seca $\left(\mathrm{g} \cdot \mathrm{kg}^{-1}\right)$ em silagens de capim Tanzânia..............................................................

11 Valores de poder tampão (mequiv.100 $\mathrm{g} \mathrm{MS}^{-1}$ ), na forragem com umidade original (MO), com polpa cítrica peletizada (MOPC) e préemurchecida (PE), nos cortes de inverno (IN) e de verão (VE)

12 Efeito do teor de matéria seca no $\mathrm{pH}$ das silagens, originadas de forragem com a umidade original $(\mathrm{MO})$ e pré emurchecida $(\mathrm{PE})$, no verão e no inverno

13 Porcentagem de NDT recuperado na ensilagem de capim Tanzânia em função dos tratamentos experimentais. 14 Custo relativo do NDT (\%) das silagens de capim Tanzânia, em função dos tratamentos experimentais 


\section{LISTA DE TABELAS}

Página

1 Médias do valor nutritivo da forragem e da silagem de capim

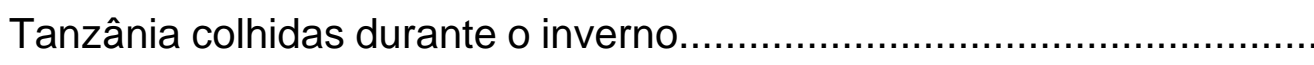

2 Médias do valor nutritivo da forragem e da silagem de capim Tanzânia colhidas durante verão.

3 Médias das perdas e dos parâmetros fermentativos da silagem de capim Tanzânia colhidas durante o inverno.

4 Médias das perdas e dos parâmetros fermentativos da silagem de capim Tanzânia colhidas durante o verão

5 Médias de condutividade elétrica (CE, ì S. $\mathrm{cm}^{-1}$ ) para os efeitos do teor de matéria seca (TMS) e do tamanho de partícula, das silagens de capim Tanzânia, produzidas no inverno e no verão.

6 Médias da produção de efluente para os efeitos da alteração do teor de matéria seca (TMS), do tamanho de partícula (PART) e da estação do ano (EST), na silagem de capim Tanzânia

7 Médias da estimativa da produção de gases (\% da matéria seca) para os efeitos do inoculante bacteriano em silagens de capim Tanzânia produzidas no verão e inverno

8 Médias da estimativa da produção de gases (\% da matéria seca) para os efeitos do tamanho de partícula (PART) e da alteração do teor de matéria seca (TMS), em silagens de capim Tanzânia colhidas durante o inverno 
9 Médias da estimativa da produção de gases (\% da matéria seca) para os efeitos do tamanho de partícula (PART) e da alteração do teor de matéria seca (TMS), em silagens de capim Tanzânia colhidas, durante o verão.

10 Médias da temperatura acumulada nas silagens pós-abertura, para os efeitos da alteração do teor de matéria seca (TMS) e da estação do ano (EST).

11 Médias de $\mathrm{pH}$ para os efeitos da alteração do teor de matéria seca (TMS), da adição de inoculante bacteriano (INOC) e da estação do ano (EST), em silagens de capim Tanzânia.

12 Médias dos teores de nitrogênio amoniacal (NA) em relação nitrogênio total $\left(\mathrm{N}-\mathrm{NH}_{3} . \mathrm{Ntotal}^{-1}, \%\right)$, para os efeitos da estação do ano (EST) e da alteração no teor de matéria seca (TMS).

13 Médias do teor de nitrogênio amoniacal (NA) em relação nitrogênio total $\left(\mathrm{N}-\mathrm{NH}_{3} \cdot \mathrm{Ntotal}^{-1}\right)$, para os efeitos da alteração do teor de matéria seca (TMS) e do tamanho de partícula (PART)

14 Médias da fração protéica B3 (\%, N total), para os efeitos da alteração do teor de matéria seca (TMS) e do tamanho de partícula (PART), na silagem de capim Tanzânia processadas durante o inverno

15 Médias da fração protéica B3 (\%, N total), para os efeitos da alteração do teor de matéria seca (TMS) e do tamanho de partícula (PART), na silagem de capim Tanzânia processadas durante o verão... 16 Médias da porcentagem de FDN (\%, MS) para os efeitos da estação do ano (EST) e da alteração do teor de matéria seca (TMS), nas silagens de capim Tanzânia

17 Médias da porcentagem de FDA (\%, MS).das silagens, para os efeitos da estação do ano (EST) e da alteração no teor de matéria seca (TMS)

18 Médias da relação hemicelulose / FDN na forragem e na silagem de capim Tanzânia, decorrentes dos tratamentos experimentais. 
19 Médias do teor de NDT (\%, MS) para os efeitos do tamanho de partícula (PART) e da alteração do teor de matéria seca (TMS), em silagens de capim Tanzânia colhidas no inverno................................... 98 20 Médias do teor de NDT (\%, MS) para os efeitos do tamanho de partícula (PART) e da alteração do teor de matéria seca (TMS), em silagens de capim Tanzânia colhidas no verão...................................... 


\section{LISTA DE ABREVIATURAS}

EST: estação do ano que foi realizada a colheita.

IN: inverno.

VE: verão.

INOC: inoculante bacteriano.

C: com a adição do inoculante bacteriano.

S: sem a adição do inoculante bacteriano.

TMS: alteração do teor de matéria seca

MO: forragem ensilada na umidade original.

MOPC: forragem ensilada com adição de polpa cítrica peletizada.

$P E:$ forragem pré-emurchecida.

PART: tamanho de partícula

PMe: forragem picada com a partícula de menor tamanho.

PMa: forragem picada com a partícula de maior tamanho.

PT: poder tampão.

NA: nitrogênio amoniacal.

CE: condutividade elétrica.

$A W$ : atividade de água.

LAB: bactérias homofermentativas.

PCP: polpa cítrica peletizada. 


\section{CONTROLE DE PERDAS NA ENSILAGEM DE CAPIM TANZÂNIA (Panicum maximum Jacq. cv. Tanzânia) SOB OS EFEITOS DO TEOR DE MATÉRIA SECA, DO TAMANHO DE PARTÍCULA, DA ESTAÇÃO DO ANO E DA PRESENÇA DO INOCULANTE BACTERIANO}

Autor: Mauricio Scoton Igarasi

Orientador: Luiz Gustavo Nussio

\section{RESUMO}

O objetivo do presente projeto de pesquisa foi a caracterização do processo de ensilagem de capim Tanzânia (Panicum maximum, Jacq.), avaliando a eficiência de colheita da forragem, as perdas durante o processo fermentativo, e o valor nutritivo da silagem. Para a colheita e captação da forragem foi utilizada uma colhedora de forragem comercial, efetuando cortes no inverno e no verão, em uma área destinada a produção de silagem. Para cada corte foram estabelecidos 12 tratamentos com 4 repetições, sendo analisados os efeitos da alteração do teor de matéria seca (forragem na umidade original, pré-emurchecida e a adição de polpa cítrica), do tamanho de partículas (2 níveis), e da aplicação ou não de aditivo bacteriano (1 milhão UFC viáveis/g de forragem ensilada). Nas amostras do material ensilado (forragem) e da silagem (após 120 dias do fechamento dos silos experimentais), foram 
analisadas o tamanho de partícula, atividade de água, condutividade elétrica, MS, EE, PB, MM, N-NH ${ }_{3}, F D A, F D N, N-F D N, N-F D A$, Lignina, nitrogênio amoniacal, $\mathrm{pH}$ e poder tampão. Também foram avaliadas as perdas de matéria seca na forma de gases, a produção de efluente, recuperação de matéria seca, além da determinação da estabilidade aeróbia da silagem. A análise estatística caracteriza-se em arranjo em parcelas subdivididas (split-plot), sendo que as principais causas de variação foram atribuídas à parcela (alteração do teor de matéria seca, tamanho de partícula, e inoculante bacteriano), e a estação do ano (inverno ou verão), foi atribuída na sub-parcela. A adição de polpa cítrica melhorou as características fermentativas ( $\mathrm{pH}$, nitrogênio amoniacal); diminuiu as perdas no processo fermentativo (efluente e gases), aumentou a recuperação de matéria seca, entretanto piorou a estabilidade aeróbica da silagem; aumentou o teor e a taxa de recuperação do NDT, contudo elevou o custo relativo do NDT. O pré emurchecimento elevou as perdas na colheita, entretanto diminuiu as perdas na fermentação (gases, efluente e recuperação de matéria seca) e a estabilidade aeróbica da silagem; diminuiu também o teor de nitrogênio amoniacal, mas não alterou $\circ \mathrm{pH}$; e apresentou os menores índices de recuperação de NDT. A redução no tamanho da partícula promoveu o aumento na densidade da silagem, entretanto não refletiu na produção de efluente e gases, porém houve a redução na recuperação de matéria seca; melhorou a estabilidade aeróbica da silagem; diminuiu o $\mathrm{pH}$, entretanto elevou o teor de nitrogênio amoniacal; não ocasionou efeito no teor, na taxa de recuperação e no custo relativo do NDT. A adição do inoculante bacteriano não refletiu em alterações nos parâmetros fermentativos $(\mathrm{pH}$ e nitrogênio amoniacal), na produção de efluentes e na recuperação de matéria seca, porém promoveu a redução na produção de gases; contudo, houve a elevação no custo relativo do NDT. No corte de verão, a melhoria no processo de ensilagem pode ser alcançado através da elevação do teor de matéria seca. A maior eficiência de recolhimento de forragem pré-emurchecida e a redução no tamanho de partícula, constitui-se em áreas promissoras para o 
desenvolvimento da indústria de equipamentos de colheita para ensilagem de forragens. 


\section{LOSSES OF TANZANIA GRASS SILAGE (Panicum maximum, Jacq. cv. Tanzania) AFFECTED BY DRY MATTER LEVEL, PARTICLE SIZE, SEASON AND BACTERIAL INOCULANT ADDITION.}

Author: Maurício Scoton Igarasi

Adviser: Luiz Gustavo Nussio

\section{SUMMARY}

The present trial aimed to evaluate the ensiling process of Tanzania grass (Panicum maximum, Jacq. cv. Tanzania), focusing on efficiency of forage chopping and harvesting, fermentation losses and nutritive value. A pull-type forage chopper was used for harvesting the winter and the following summer cuts in a commercial grass field. In both cuts (sub-plot), twelve treatments, with four replicates each, were assigned to a split plot experimental design, where main (plot) effects were combined into three factors: dry matter level (green chopped, wilted and pelleted citrus pulp-PCP added); particle size (small and large) and lactic acid bacteria (LAB, 1 million CFU. $g^{-1}$ forage) inoculant, (w or $\mathrm{w} / \mathrm{o})$. Forage recovery was measured in the field by using $1 \times 1 \mathrm{~m}$ quadrats. Silage fermentation losses were evaluated in 20L plastic buckets provided with Bunsen type valve and effluent absorbent substrate. Forage and silage samples were sieved in a Penn State Forage Separator for particle size measurements 
and analyzed for water activity (Aw), electrical conductivity (EC), DM, CP, NDF, ADF,EE, ash, $\mathrm{NNH}_{3}, \mathrm{ADIN}, \mathrm{NDIN}, \mathrm{pH}$ and buffering capacity (BC). After the silos were unloaded, dry matter losses, recovery and aerobic stability were measured. The addition of PCP enhanced the fermentation parameters (lower $\mathrm{pH}, \mathrm{N}^{-} \mathrm{NH}_{3}$, effluent and gases yield), dry matter and TDN recovery rates and the observed aerobic stability was offset by the improved fermentation profile. Wilting also improved fermentation parameters and aerobic stability, with no changes in silage $\mathrm{pH}$, however, led to a poor TDN recovery rate as a result of increased chopping and harvesting losses. Smaller silage particle size determined increases in fresh and dry matter bulk densities, and lower $\mathrm{pH}$ levels, which were associated with better aerobic stability. Gases and effluent yields as well TDN recovery rate and cost, remained unchanged with particle size reduction even tough, higher $\mathrm{N}-\mathrm{NH}_{3}$ levels and decreased dry matter recovery rates were observed. $L A B$ inoculant resulted in higher forage TDN cost, mainly due to unchanged silage fermentation profile, except for lowered gases yield. In the summer cut, an improved Tanzania grass ensiling process might be achieved either by lowering forage moisture content and/or reducing particle size. The machinery industry should play a major role in accomplishing the upgraded needs in forage choppers market. 


\section{INTRODUÇÃO}

A menor produção das forragens durante o "inverno", tem sido apontada como um dos fatores que mais contribui para a baixa produtividade dos rebanhos. A queda acentuada nos índices de produção na pecuária, tanto na produção leiteira como na produção de carne, se deve a redução na capacidade de suporte das áreas de pastagem, tendo como consequência a perda de peso e a maior idade ao abate dos animais. Assim, pesquisadores já na década de setenta, diagnosticaram que a estacionalidade de produção de forragens, devido à filosofia do manejo adotado, vem dificultando a rentabilidade da atividade pecuária, pois o potencial de produção do animal no país não pode ser alcançado, uma vez que a lotação das pastagens é ajustada em função da produção mínima de "inverno".

No intuito de alterar esse cenário encontrado na maior parte do país, tem-se buscado intensificar os processos de produção, nos quais estão relacionados a aplicação de formas do manejo adequado para as forrageiras, adubação racional das áreas proporcionando aumento na produção de matéria seca e melhor eficiência de utilização destas pastagens. Porém, existem outros fatores que interferem na eficiência de utilização, como a estacionalidade de produção encontrada nas gramíneas tropicais, gerando oscilações entre suprimento (S) e demanda (D) de forragem. O balanço anual entre $S$ e $D$ é utilizado para estabelecer taxas de lotação potencial e balancear a demanda estacional de alimento com o padrão esperado de suprimento de forragem. Desse balanço é que resultam as decisões quanto à necessidade de suplementação alimentar para elevação ou a manutenção da produtividade. 
Algumas alternativas são apontadas no sentido de atingir-se o equilíbrio, entre elas, a intensificação de produção de volumosos suplementares durante o verão, visando a conservação de forragem para o inverno.

Desde a década de 70 verificou-se um grande potencial na produção de silagem de gramíneas tropicais, entretanto, devido principalmente a deficiência de equipamentos compatíveis para colher e picar forragens perenes de alto potencial produtivo, não houve implementação dessa tecnologia. Nos últimos anos, a indústria nacional começou a desenvolver unidades colhedoras com maior capacidade de colheita e maior competência na picagem da partícula, iniciando uma nova fase na conservação de forragem, com a possibilidade de conservação de gramíneas perenes.

Os sistemas produtivos observaram a possibilidade de ensilar pastagens excedentes, ou ainda destinar campos exclusivos para produção de silagem, visto o seu cus to reduzido por tonelada de matéria seca em relação as plantas tradicionais como milho e sorgo. O sistema de produção de silagem de forrageiras, assegura uma amplitude de alternativas de manejo, que podem garantir o abastecimento de volumosos para o rebanho, desde que haja um planejamento prévio e o uso de recursos como adubações estratégicas.

Entretanto, devido as características intrínsecas das plantas forrageiras observadas no estádio fisiológico ideal para o corte, como a alta umidade e baixo teores de carboidratos solúveis, tem havido o questionamento sobre as perdas no valor nutritivo e em matéria seca. Assim, o conjunto de perdas vinculadas a ensilagem, determina a sensível redução na quantidade de nutrientes que chega ao animal, ocasionando inflação dos custos de produção e questionamento quanto a economicidade.

Com o objetivo de reduzir perdas nesse processo, buscourse a possibilidade de adicionar a ensilagem de gramíneas tropicais ingredientes que atuem no sentido de melhorar as características fermentativas, minimizando perdas nessa etapa. As principais alternativas elucidadas pela literatura tem sido no sentido de aumentar o teor de matéria seca, através do pré- 
emurchecimento ou da adição de materiais absorventes, minimizando as perdas por efluente, além da adição de inoculantes bacterianos, que visam aumentar a população de bactérias desejáveis. Ainda, a alteração de práticas de manejo associadas ao processo de ensilagem, como a redução no tamanho da partícula picada, poderia promover a melhor compactação do material ensilado, maior superfície de contato entre substrato e microrganismo, e maior eficiência na eliminação do oxigênio da massa.

O presente trabalho teve como objetivo fornecer informações sobre perdas associadas a ensilagem de capim Tanzânia, utilizando tratamentos que consideraram os efeitos de umidade, adição de substrato fermentável, redução no tamanho de partícula e a adição de inoculante bacteriano. As possíveis ações isoladas e/ou associadas desses ingredientes conjuntamente às práticas de manejo, oferecem condições de contribuir na redução de perdas vinculadas àensilagem de gramíneas tropicais. 


\section{REVISÃO DE LITERATURA}

2.1 Potencial da ensilagem de capins tropicais

É indiscutível o papel da silagem como volumoso suplementar na alimentação de ruminantes em períodos de escassez de forragem. A silagem de capim vem surgindo como uma alternativa æ̀s culturas tradicionais, tendo como vantagens as características de uma cultura perene, possibilidade de suportar elevadas lotações na propriedade e apresentar grande flexibilidade em manejo na tomada de decisões.

A estacionalidade de produção das plantas do gênero Panicum maximum parece ser característica limitante para a exploração sob pastejo, se analisada sob o aspecto de porcentagem de produção de forragem durante o inverno em relação à produção anual ou total. Pedreira (1972) e Jank (1994) indicaram que o capim colonião só produz cerca de 3\% (Jank, 1994) a 12\% (Pedreira, 1972) da produção anual durante o inverno.

A produtividade média está situada entre 20 a $30 \mathrm{t} \mathrm{MS} \cdot \mathrm{ha}^{-1} \cdot \mathrm{ano}^{-1}$, segundo Jank (1994), o qual observou a superioridade do Tanzânia 1, Mombaça e Tobiatã que apresentaram produção de matéria seca 86\%, 136\% e 96\% maiores que o colonião. Jank \& Costa (1990), citados por Corsi \& Santos (1995) observaram produção de capim Tanzânia de 25,6 tha ${ }^{-1}$ de MS foliar, sendo que $10,5 \%$ da produção anual ocorreu no inverno. Quanto à qualidade, Euclides et al. (1993) observaram no capim Tanzânia, nos estádios imaturos e 
maduro os teores de PB de 16,1\% e 7,4\%, e de digestibilidade "in vitro" da matéria orgânica de $61,3 \%$ e $56,7 \%$, respectivamente.

A maioria das espécies forrageiras sofre declínio no seu valor nutritivo com o aumento da idade. Isto é resultado da menor relação haste/folha combinada com a crescente lignificação da parede celular, sendo que o estádio de maturação tem maior influência no valor nutritivo das forragens. Contudo, esse fator pode ser controlado através do manejo adequado de pastejo e do momento do corte da forragem para conservação (Hoveland \& Monson, 1994).

O valor nutritivo das plantas forrageiras é determinado pela sua composição química, principalmente pelos teores de proteína bruta e de fibra em detergente ácido (FDA), responsáveis diretos pela digestibilidade da matéria seca (Nussio et al., 1998; Euclides et al., 1995). A lignina exerce grande influência sobre a taxa de degradação e a degradabilidade efetiva da parede celular dos alimentos volumosos (Van Soest, 1994), sendo um fator determinante do conteúdo de energia digestível das plantas forrageiras. A fração fibra detergente neutro (FDN) tem grande efeito sobre a ingestão voluntária de alimentos fornecidos aos animais ruminantes (Mertens, 1994).

Gramíneas apresentam baixo teor de carboidratos solúveis e as maiores mudanças que ocorrem na composição química das forrageiras são aquelas decorrentes da maturidade da planta (Balsalobre et al., 2001). À medida que a planta amadurece, a produção dos componentes potencialmente digestíveis (carboidratos solúveis, proteína, etc) tende a decrescer, sendo que a proporção de lignina, celulose e hemicelulose e outras frações indigestíveis (cutina, sílica, etc) se elevam, resultando em menor digestibilidade (Euclides, 1995), devido à diminuição da relação folha/haste.

As gramíneas forrageiras tropicais (Andrade \& Gomide, 1971; Próspero, 1972 e Silveira et al., 1973a) aumentam sua produção por área, tendo em contrapartida seu valor nutritivo diminuído, com o avanço do estado fisiológico. Consequentemente, o produto obtido no processo de ensilagem também será de menor valor nutritivo se for colhido tardiamente. Por outro lado, quando são 
ensiladas em estádio inicial de crescimento vegetativo, segundo Woolford (1984), três de suas características podem interferir sobre o processo de ensilagem: 1) alto teor de umidade; 2) alta capacidade tampão e 3) baixos teores de carboidratos solúveis. Tais fatores influenciam negativamente sobre 0 processo fermentativo, impedindo o rápido decréscimo do $\mathrm{pH}$ até níveis adequados (3,8 a 4,2), se sujeitando assim, æ̀s fermentações secundárias indesejáveis, e consequentemente prejudicando a qualidade do produto preservado.

Para um rápido abaixamento do $\mathrm{pH}$ é imprescindível que exista no ambiente quantidade suficiente de carboidratos solúveis a serem fermentados pelas bactérias, e que o poder tampão não seja capaz de impedir o abaixamento do $\mathrm{pH}$ aos níveis desejados. A relação entre o teor de carboidratos solúveis e o poder tampão da forragem foi utilizada por WIESSBACH et al. (1974) para prever a qualidade de produtos ensilados através de uma equação.

Segundo Oude Elferink et al. (1999), onde citam a fórmula proposta por Weissbach \& Honig (1996), relatam que a capacidade de fermentação (CF) é diretamente proporcional aos teores de matéria seca (MS) e de carboidratos solúveis (CS), e inversamente proporcional ao poder tampão (PT) (CP = MS + 8 $x$ CS/PT), dessa forma, pode-se propor estratégias de manejo afim de otimizar as características da planta, e assim proporcionar adequada fermentação no processo de conservação de forragem.

Com relação ao poder tampão, Playne \& McDonald (1966) discutem que esse é devido em 68 - 80\% de sua magnitude a fração ânion da forragem, representados pelos sais de ácidos orgânicos, ortofosfatos, sulfatos, nitratos e cloretos, sendo que entre os pHs 6 e 4, somente os ânions de sais orgânicos e os ortofosfatos são tamponantes, sendo o efeito do ortofosfato menor. A fração proteica apresenta impacto reduzido sobre o poder tampão.

Zierenberg et al. (2001) verificaram o potencial de gramíneas do Chaco Central, no Paraguai, ao apresentarem fermentação adequada quando ensiladas, sendo essas: Gatton (P.maximum), Estrela (C. plectostachyus), 
Pangola (D. eriantha), Tifton (Cynodon sp), Tanzânia (P.maximum) e Digitaria milanjiana. Verificaram que todas essas gramíneas tiveram como característica a baixa concentração de carboidratos solúveis, entretanto, houve uma menor capacidade tamponante, o que favoreceu o processo fermentativo. Contudo, a relação CS/PT, foi menor que a recomendada por Weissbach (1968, citado por Zierenberg et al., 2001), que mencionam o valor crítico 3 , sendo que as gramíneas estudadas apresentaram valores de 1,$1 ; 1,0 ; 2,0,9 ; 0,4$; e 1,0, respectivamente. Testando a rápida fermentação e o declínio do $\mathrm{pH}$ da silagem após 22 horas de vedação do silo, verificaram que apenas o capim Estrela alcançou pH satisfatório ( $\mathrm{pH}=4,2$ ), e o capim Tanzânia foi o que apresentou o $\mathrm{pH}$ mais elevado $(\mathrm{pH}=5,4)$. Confirmando o baixo teor de carboidratos solúveis nas respectivas gramíneas, ao adicionar $2 \%$ de sucrose no material ensilado, 0 pH atingiu níveis adequados, inferiores a 4,3, após 22 horas, com exceção da Tanzânia que obteve pH de 4,8.

Em relação a dinâmica no processo de ensilagem, o material depois de cortado no campo, é submetido ao processo de respiração aeróbica, sendo esse realizado por microrganismos tolerantes ao oxigênio, os quais incluem bactérias aeróbicas, leveduras e fungos. Nessa primeira etapa, esses microrganismos convertem carboidratos solúveis da planta em dióxido de carbono e água, gerando calor, o que representa energia perdida do material ensilado. Esse processo aeróbico se estende até que todo o oxigênio seja consumido ou os açúcares livres estejam esgotados (Vilela, 1998).

McDonald et al. (1991) mencionam que o primeiro objetivo na conservação de plantas forrageiras, sob fermentação natural, é alcançar condições anaeróbicas, minimizando perdas de nutrientes e evitando mudanças adversas na composição química da planta. Contudo, além da anaerobiose que permite o crescimento de microrganismos anaeróbicos, é necessário um adequado aporte de substrato na forma de carboidratos solúveis para suprir as bactérias láticas. 
Os princípios básicos da ensilagem incluem, a obtenção de condição anaeróbica dentro do silo, como resultado de material picado homogeniamente visando a compactação satisfatória e expulsão do ar. Conjuntamente, consistem no controle das atividades microbianas através da acidificação do meio com subprodutos da fermentação microbiana, principalmente o ácido lático, que aumenta a concentração hidrogeniônica do meio inibindo o desenvolvimento de bactérias produtoras de ácido butírico (McDonald \& Henderson, 1981). O ambiente deve fornecer condições para a seleção dos microrganismos (Lactobacilos) mais eficientes à produção de ácido lático, preferencialmente a colonização de microrganismos heterofermentativos, sendo prioritários fatores como: $\mathrm{pH}$, atividade de água, temperatura e ácidos orgânicos (Pitt, 1997).

Ë importante tentar inibir o crescimento das bactérias produtoras de ácido butírico. Estas bactérias estão na forragem colhida na forma de esporos e começam a se multiplicar assim que as condições do silo se tornam anaeróbicas, sendo prejudiciais na conservação da forragem pois produzem ácido butírico e degradam aminoácidos em uma variedade de compostos de baixo valor nutricional (McDonald et al., 1991). As enterobactérias, anaeróbicas facultativas, fermentam açúcares em ácido acético e também tem a habilidade em degradar aminoácidos, sendo que segundo Woolford (1984), seu crescimento é inibido pela queda do pH decorrente da fermentação lática.

Vilela (1998) destaca que durante essa primeira fase da fermentação pode haver intensa proteólise, resultado da geração de peptídeos e aminoácidos, e depois decompostos em amônia e aminas. A maioria das enzimas vegetais que degradam proteínas são ativas somente em $\mathrm{pH}$ superior à 5 , sendo que a rápida acidificação desnatura essas enzimas e minimiza as perdas de proteína, melhorando a aceitação pelos animais. Tem sido observados níveis de $50 \%$ da proteína total da planta degradada nesse processo, ocasionando uma alto teor de amônia e aminas na silagem, o que é 
indicativo de perdas no processo predispondo ao menor consumo voluntário de silagem pelos animais. (McDonald et al., 1991)

A silagem é considerada de qualidade satisfatória se apresentar $\mathrm{pH}$ inferior a 4,2, ácido butírico inferior a 0,2\%, na MS, e $\mathrm{N}$ amoniacal inferior ou igual a $11-12 \%$ do $N$ total (Silveira, 1975). Segundo McCullough (1977) a fermentação ideal no silo é esperada quando a forragem ensilada apresente teor de matéria seca entre 28 e 34\%, associada ao teor de carboidratos solúveis variando entre 6 e $8 \%$ na MS. Kearney \& Kennedy (1962) mencionam o limiar como sendo de $15 \%$ de carboidratos solúveis na matéria seca, condição essa que seria suficiente, desde que o poder tampão não fosse elevado. Associado ao padrão de fermentação, o consumo de matéria seca da silagem seria maximizado quando apresentasse teor de matéria seca em torno de 35\% (Jackson \& Forbes, 1970; Andrade \& Lavezzo, 1998). O pH ideal para a conservação é dependente da umidade do material e também da temperatura, sendo que em silagens com teor matéria seca superior a $20 \%$, é aceitável um $\mathrm{pH}$ equivalente a 4 , para obter-ser conservação satifatória (McDonald et al., 1991).

2.2 Teor de matéria seca

Embora as gramíneas tropicais para a ensilagem necessitem ser colhidas no seu estádio vegetativo precoce, enquanto a digestibilidade e o teor de proteína permanecem elevados, existe o inconveniente de que nessa oportunidade o teor de umidade é maior, podendo afetar negativamente a qualidade da fermentação da silagem (McDonald et al., 1991). Segundo Silveira et al. (1980), nesse estádio de maturidade, o teor de umidade apresentado por capins tropicais é excessivo, fato que prejudica a fermentação, incrementa as perdas por drenagem e deprime o consumo voluntário. Para diminuir riscos e 
obter silagem de melhor qualidade há algumas alternativas, como fornecimento de aditivos absorventes e o pré-emurchecimento da forragem.

Retratando a dinâmica microbiana durante 0 processo de emurchecimento da forragem, Rammer (1996), comenta que os aumentos no teor de matéria seca na forragem estão associadas a sensíveis reduções na população microbiana, entretanto a percentagem de bactérias produtoras de ácido lático ( $L A B)$ e enterobactéria é aumentada. As LAB apresentam maior tolerância relativa à redução da umidade que as bactérias do gênero Clostridium sp., as quais são responsáveis pelas fermentações indesejáveis, sendo portanto interessante a inibição da sua atividade. Em alguns casos, a baixa atividade microbiana da silagem pré-emurchecida quando comparada a silagem produzida com a umidade original, é refletida pela baixa concentração de ácidos orgânicos, alto $\mathrm{pH}$ e uma maior concentração residual de carboidratos solúveis.

Wieringa (1960) destaca que os microrganismos do gênero Clostridium sp. são mais inibidos pela falta de umidade do que pela acidez do meio, podendo tolerar altos níveis de ácidos e hidrogênio quando em meio úmido, e que sua resistência é diretamente proporcional ao teor de umidade.

$\mathrm{O}$ conceito de atividade de água (AW) tem sido mais completo para relacionar a umidade na forragem com o crescimento de Clostridium sp. A AW aumenta com a umidade do material, sendo que Greenhill (1964), propôs uma fórmula para sua determinação, na qual a $A W$ é mensurada em termos da pressão de vapor relativa, conforme a equação apresentada abaixo:

$\mathrm{AW}=1-\mathrm{c} / \mathrm{m}$,

Assim, c é uma constante, determinada pela somatória dos pesos das moléculas e dos íons no suco da planta, m é a umidade existente, expressada em gramas $(\mathrm{g})$ de água por quilo $(\mathrm{kg})$ de matéria seca da forragem.

Segundo Rose (1983), a AW realiza a mensuração da água livre, sendo uma medida conveniente, visto que o crescimento e metabolismo dos microrganismos necessita da presença de água livre. A AW pode ser reduzida 
pela remoção de água, ou pela adição de solutos na fase aquosa, destacando a AW por sua estreita relação com a umidade relativa e a pressão osmótica do material. Concordando McDonald et al. (1991), mencionam que a AW foi diminuída tanto pela adição de cloreto de sódio ou pelo emurchecimento da forragem, sendo observado abaixamento no crescimento de Clostridium sp. Destacam ainda, que o Clostridium sp é inibido com a atividade de água abaixo de 0,94, sendo esses mais sensíveis do que as bactérias produtoras de ácido láctico (LAB).

A remoção parcial da água da planta tem efeito de reduzir a incidência de fermentações secundárias, melhorando a qualidade da silagem, a digestibilidade, o consumo voluntário (Lavezzo, 1985; Vilela, 1998, Wright et al., 2000). Concordando, Tosi et al. (1999), Yan et al. (1998) e Berto \& Muhlbach (1997), obtiveram valores inferiores de N-amoniacal em silagem préemurchecidas em relação a silagem realizada com a umidade original da forragem.

Estudos sobre emurchecimento produzem resultados adversos devido æ̀s condições climáticas variáveis (Muhlbach, 1999; McDonald et al., 1991). Em condições úmidas e quentes como nos trópicos muita vezes a secagem não é rápida, sendo que as perdas bioquímicas da respiração podem ser maiores que as perdas da forragem não emurchecida, resultando em menor digestibilidade da matéria seca (Thomas \& Thomas, 1985). Diferente dos trópicos semi áridos, onde se pode obter emurchecimento em 3 ou 4 horas (Michelena \& Molina, 1990, Alberto et al., 1993), sem resultar na diminuição da digestibilidade e ainda propiciando adequada fermentação da silagem (Thomas \& Thomas, 1985).

O emurchecimento aumenta o teor de matéria seca, porém esse valor nem sempre atinge níveis adequados (Lavezzo et al., 1993; Machado Filho \& Muhlbach, 1986; e Silveira, 1973 a, b), além disso o valor nutritivo da silagem também poderá ser reduzido, devido a maior decomposição aeróbia da MS por fungos e leveduras (Silveira et al., 1973b). São características do préemurchecimento: dependência de condições climáticas para desidratar o 
material, maior custo de produção de silagem, e maior necessidade de equipamentos e mão de obra. Também, a desidratação diminui os teores de carboidratos solúveis, reduzindo a eficiência fermentativa devido à queda do teor de carboidratos totais (de Faria, 1971).

Se o período de secagem durar vários dias, os carboidratos solúveis podem ser consumidos, o teor de $\mathrm{N}$ protéico pode ser diminuído e a desaminação de aminoácidos aumentada (Henderson, 1993). Tosi et al. (1999) verificaram em um experimento com capim elefante, que o emurchecimento durante 24 horas diminuiu a quantidade de carboidratos solúveis e a DIVMS, apesar de reduzir a elevação do teor de $\mathrm{N}$-amoniacal da silagem.

McGechan et al. (2000) discutem a possibilidade de utilizar a maceração na ceifa da forragem como alternativa para promover uma desidratação mais rápida, possibilitando o recolhimento em período mais curto, o que evitaria que a forragem fosse reidratada durante o período noturno; e também diminuindo a possibilidade de chuvas, minimizando assim as perdas em relação ao período de seca. Com a maceração seria possível a elevação mais rápida do teor de matéria seca, para aproximadamente $30 \%$, no qual as perdas por efluentes seriam mínimas.

Berto \& Muhlbach (1997) trabalhando com silagem de aveia no sul do Brasil, verificaram que o emurchecimento $(31,22 \% \mathrm{MS})$, determinou menor produção de ácidos totais, reduziu a produção de amônia e ácido butírico, conservou açúcares solúveis na silagem, e evitou a produção de efluentes.

Em uma revisão realizada por Wright et al. (2000), em 85 trabalhos de pesquisa comparando o desempenho de animais recebendo silagem com e sem pré-emurchecimento, verificou um melhor desempenho de animais nos tratamentos contendo silagem pré-emurchecida, o que foi explicado pelo maior consumo de matéria seca e de energia metabolizável. Isso foi devido a fatores associados com a taxa e extensão de desidratação no campo, quando comparados a qualidade do material ensilado na umidade original (digestibilidade da matéria seca, proteína bruta e N-amoniacal). 
O processo de aditivação com materiais absorventes, promove um aumento no teor de matéria seca, garantindo melhores condições para as fermentações desejáveis (Jones \& Jones, 1995). Além disso, ocorre a redução da exigência de carboidratos solúveis, garantindo assim um processo fermentativo satisfatório, impedindo o desenvolvimento de microrganismos indesejáveis e tornando a silagem de gramíneas tropicais, um alimento de valor nutricional adequado e de baixo custo de produção (Balsalobre et al., 2001; Vilela, 1998; Lavezzo, 1985)

O ingrediente a ser aditivado no capim deve apresentar alto teor de matéria seca, alta capacidade de absorver água, boa palatabilidade e fornecer carboidratos para a fermentação. A adição deverá ser calculada afim que a mistura atinja o teor de matéria seca entre 28 a 30\% (ideal para a fermentação), evitando assim, ocorrência de efluentes que causam perdas, e acelerando o desenvolvimento de bactérias láticas. Deve ser de fácil manipulação, boa disponibilidade no mercado e baixo custo de aquisição. Entretanto, o uso de aditivos de baixo valor nutritivo, determinou a produção de silagem de baixo valor nutritivo (Lavezzo, 1993, Tosi et al., 1989).

A literatura relata que as gramíneas tropicais apresentam um elevado teor de umidade e baixo teor de carboidratos solúveis, e esses fatores associados prejudicam significativamente o processo fermentativo, originando silagens ácidas e de baixo consumo voluntário pelos animais (Zierenberg et al., 2001; Nussio et al., 2000; Morais, 1999; Vilela, 1998). Balsalobre et al. (2001), sugerem que para se obter silagens de capim de qualidade satisfatória e perdas reduzidas, partindo de uma forragem com baixos teores de carboidratos solúveis e altos teor de umidade, deve-se corrigir essas restrições com a adição de açúcares e promover aumento nos teores de matéria seca, acelerando assim a fermentação inicial para que o pH apresente declínio mais acelerado.

A polpa cítrica torna-se uma alternativa interessante para a nutrição animal em regiões produtoras de citrus, visto a alta qualidade do ingrediente e 0 baixo custo de aquisição. A alta capacidade de absorção de água e a 
concentração elevada de carboidratos solúveis, substratos disponíveis para as bactérias fermentadoras, possibilitou a inclusão da polpa cítrica na ensilagem de gramíneas tropicais, corrigindo suas principais restrições em relação ao processo fermentativo da ensilagem. Morais (1999) sugere que, dos produtos disponíveis comercialmente no Brasil, a polpa cítrica apresenta um grande potencial para ser utilizada como aditivo de silagem de gramíneas, devido as suas características qualitativas.

Segundo Vilela (1998), a polpa cítrica é capaz de absorver $145 \%$ de seu peso em umidade, quando em contato com forrageiras úmidas, preservando assim nutrientes que seriam perdidos na forma de efluente ou fermentações indesejáveis. A dose recomendada na mistura varia de $7 \%$ a $20 \%$ na matéria verde do capim, e além de melhorar a fermentação no silo, aumenta a aceitação da silagem pelos animais.

Peres (1997) observou que a inclusão de até $10 \%$ de polpa cítrica na mistura da silagem, aumentou o teor de MS, enquanto que a adição de $10 \mathrm{e}$ $15 \%$ de polpa cítrica produziu resultados similares a adição de $10 \%$ de fubá, sendo a polpa bastante eficiente em absorver umidade, aumentou o consumo voluntário pelos animais como consequência do aumento na digestibilidade da matéria seca e do teor de NDT.

Corrêa \& Cordeiro (2000) obtiveram silagem de capim Tanzânia, sem pré-emurchecimento e sem aditivo, com as seguintes características: $20-22 \%$ de MS; 5,8 - 7,0\% de PB; pH de 4,4 - 4,7; 11,0 - 19,0\% de $\mathrm{N}$ amoniacal em relação ao $\mathrm{N}$ total $\left(\mathrm{N}-\mathrm{NH}_{3} . \mathrm{N}\right.$ total $\left.^{-1}\right)$, e $46-50 \%$ de digestibilidade "in vitro" da MS (DIVMS). Ao se ensilar capim Tanzânia com polpa cítrica (6-8\%), houve melhora aparente na fermentação observada pelas características sensoriais, que apresentou a seguinte composição: $24 \%$ de $\mathrm{MS}, 7,0 \%$ de PB, pH de 4,4, $10,8 \%$ de $\mathrm{N} \mathrm{NH}_{3} \cdot \mathrm{N}^{-1}$ total e $51 \%$ de DIVMS, sendo consideradas silagens de qualidade média.

A adição de polpa cítrica em silagens de gramíneas tropicais provocou um aumento no teor de matéria seca da silagem e na concentração de 
carboidratos solúveis, proporcionando melhor perfil de fermentação, representado por menores pH e $\mathrm{N}$-amoniacal (Evangelista et al., 1996a, Evangelista et al., 1996b; Pedreira et al., 2001).

Aguiar et al. (2001) aditivaram silagens de capim Tanzânia com três níveis de polpa cítrica $(5,10$ e 15\%), e também realizaram o préemurchecimento como tratamento comparativo, constatando que houve uma queda no $\mathrm{pH}$ da silagem, com o acréscimo de carboidratos solúvel via polpa cítrica. O aumento da matéria seca através da pré-emurchecimento também melhorou as características fermentativas, e por conseguinte o nível de matéria seca do tratamento contendo o pré-emurchecimento, foi semelhante ao tratamento com adição de $10 \%$ de polpa cítrica. Ainda assim, a adição de polpa cítrica apresentou menor $\mathrm{pH}$, mostrando que a adição de açúcares solúveis promoveu alterações benéficas na fermentação, adicionais a aquelas observadas pela exclusiva alteração da umidade da massa ensilada através do pré-emurchecimento.

\subsection{Tamanho de partículas}

O tamanho da partícula é um importante fator na produção de silagem, influenciando o requerimento de potência na colhedora, densidade no transporte e no silo, e valor nutricional do produto final (Gale \& Knight, 1979). Do ponto de vista nutricional, a diminuição no tamanho de partícula pode interferir no aumento da taxa de passagem, provocando maior consumo voluntário, e por consequência aumentando o desempenho de animais.

$O$ processamento físico através da picagem e esmagamento pode melhorar o processo de conservação da silagem, permitindo melhor acomodação do material dentro do silo, diminuindo a fase aeróbica da ensilagem. Lavezzo (1985) recomendou que a trituração de capim visando a ensilagem deve ser em partículas de 3 a $5 \mathrm{~cm}$ de tamanho, para permitir uma 
melhor compactação e, por conseguinte garantindo um ambiente anaeróbico, mais rapidamente. Tamanhos de partículas mais reduzidos podem favorecer a fermentação, facilitando a compactação, promovendo maior superfície de contato entre substrato e microrganismos e disponibilizando mais conteúdo celular (Aguiar et al., 2001).

Ao comparar as características fermentativas e de ingestão voluntária em 34 silagens, sob diferentes tamanhos de partículas, Dulphy \& Demarquilly (1973), relataram que a qualidade de conservação da silagem foi melhor em silagens finamente picadas que aquelas sob partículas maiores. $\mathrm{O} p \mathrm{H}, \mathrm{a}$ porcentagem de proteína degradada em amônia, o conteúdo de ácido butírico e o total de ácidos graxos voláteis foram baixos, e o conteúdo de ácido lático foi alto na silagem finamente picada, além de apresentar maior ingestão de MS pelos animais.

O tamanho de partícula da forragem a ser ensilada é questionado por vários autores, havendo dúvidas entre os benefícios derivados da fina picagem. Uma melhor compactação no silo e melhoria nas propriedades fermentativas é geralmente conflitante com o aumentando nas perdas ocorridas na forma de líquido intracelular, devido ao maior rompimento da parede celular, seja no ato da picagem, por extravasamento ou na forma de efluente no silo. Segundo Dulphy \& Demarquilly (1973) e Woolford (1984), o aumento da densidade proporcionado pela picagem fina do material, facilita a expulsão de ar, levando contudo àmaior perda por efluentes devido ao rompimento da parede celular e ao extravasamento exagerado do conteúdo celular. Segundo Woolford (1984), ainda não está estabelecida a relação entre a intensidade do processamento físico e o extravasamento de suco da célula, havendo questionamentos, pois nem sempre a picagem da forragem promove a liberação do conteúdo celular, podendo haver dilaceração e esmagamento, ao invés de corte preciso. Assim, o tamanho médio de partículas não está necessariamente relacionado com aumento da carga de efluente na massa ensilada. 
Pauly (1999) relata que o efeito de diferentes tratamentos na picagem da forragem, ou seja, na ruptura da parede celular da planta, ocasionam a drenagem do conteúdo celular em diferentes proporções, podendo ser quantificado por meio da determinação da condutividade elétrica (CE), a qual corresponde a concentração iônica do fluído liberado pela planta. Portanto amostras com maior drenagem de conteúdo celular, contendo maior concentração de íons, apresentam maior CE, sendo que a extensão do prejuízo causado pela ruptura celular das plantas pode ser estudada através da CE (Kraus et al, 1997). Com isso, a condutividade elétrica se apresenta como uma interessante e poderosa ferramenta para a avaliação do dano físico causado æ̀s partículas durante a picagem.

\subsection{Perdas por gases e efluentes}

As perdas por gases estão associadas ao perfil de fermentação ocorrido na silagem, sendo que as menores perdas são ocasionadas pelas bactérias homofermentativas utilizando glucose como substrato para a síntese de lactato. Entretanto, quando bactérias heterofermentativas, enterobactérias e leveduras produzem álcool (manitol ou etanol), ocorre um aumento considerável na perdas por gases, sendo as maiores perdas associadas a fermentação butírica, promovida pelos Clostrídeos (McDonald et al., 1991).

Segundo Balsalobre et al (2001), na ensilagem de gramíneas tropicais, devido as características da planta e do manejo de produção imposto a essa forragem, cria-se um ambiente propício para o desenvolvimento de Clostrídeos, resultando em fermentação indesejável, sendo a principal fonte na perdas por produção de gases.

Outra forma de perda de valor nutritivo da silagem é através da produção de efluente, sendo influenciada pelo teor de matéria seca da cultura ensilada, tipo de silo, grau de compactação e o processamento físico da forragem. Em 
forrageiras ensiladas com alta umidade, as perdas de matéria seca por efluente podem exceder $10 \%$, sendo que em teores de matéria seca em torno de $30 \%$, a produção de efluente pode ser pouco significativa (Haigh, 1999; Jones \& Jones, 1995). Alguns estudos tem mostrado relação negativa entre o teor de matéria seca contido na forragem ensilada e o volume de efluente produzido, sendo que através do efluente são drenados em solução, componentes nitrogenados, açúcares e minerais, ocasionando uma somatória de perdas no valor nutritivo do alimento (Haigh, 1999; Reynolds et al., 1995; Pitt, et al., 1987; O' Donnell et al., 1997; Fisher et al., 1981).

Loures (2000) menciona que para se produzir silagens de qualidade satisfatória, é necessário que se promova intensa compactação, pois essa está diretamente relacionada coma densidade da massa ensilada. No entanto, quanto maior a compactação da massa ensilada, maior a chance de haver aumentos na produção de efluentes, estando, esse efeito, dependente do teor de matéria seca da planta ensilada. A autora testou dois teores de MS (13 e 25\%) na massa ensilada, sob diferentes níveis de compactação, havendo maiores perdas por efluente associadas ao teor de MS reduzido.

O'Donnell et al. (1997) analisaram a produção de efluente em forragens com baixo teor de matéria seca $(18,5 \%$ e $14,4 \%)$ sob diferentes pressões na compactação da forragem, e concluíram que houve uma relação linear positiva entre a pressão exercida e a produção de efluente nos dois teores de matéria seca analisados.

Balsalobre et al. (2001) discutem que a redução do tamanho de corte da forragem pode ser uma alternativa na redução da fermentação butírica, por promover maior compactação e contato entre substrato e bactérias fermentadoras, o que poderia provocar uma maior produção de lactato e queda mais rápida no $\mathrm{pH}$. No entanto, em silagens com baixos teores de matéria seca, o menor tamanho de partículas pode provocar aumento na atividade de água e maior perda por efluente. Desse modo, não haveria redução nos níveis de perdas totais, mas provavelmente substituição na contribuição. Em silagens 
contendo maiores teores de MS, com a diminuição no tamanho de partícula, deverá promover redução nos níveis totais de perdas, pois promove um mínimo impacto sobre a geração de efluentes, devido a alta pressão osmótica associada a sensível redução na atividade de água.

Resultados similares foram apresentados por Aguiar et al. (2000), que colheram capim Tanzânia com 60 dias de rebrota (20\% de MS) e associaram à três níveis de polpa cítrica (0, 5 e 10\% na base da matéria original do capim), sob três tamanhos de partículas, e realizaram a quantificação das perdas por efluente e por gases. A adição de polpa cítrica reduziu as perdas por efluente, assim como as perdas totais. A redução no tamanho de partícula na forragem exclusiva, não foi efetiva na redução das perdas totais, pois apesar de reduzir a perdas por gases, estimulou a produção de efluentes. Entretanto, na presença de polpa cítrica, a redução do tamanho de partículas da forragem, foi positiva na redução das perdas por gases e totais.

\subsection{Inoculante bacteriano}

Os aditivos bacterianos são estimulantes de fermentação, sendo culturas vivas de Lactobacillus, Pedicoccus ou Streptococcus, com as espécies predominantes sendo Lactobacillus plantarum e/ou Streptococcus faecium, havendo grande diversidade genética entre as bactérias láticas (Vilela, 1998). As bactérias que compõem os inoculantes de silagens fermentam açúcares (glicose e frutose) em ácido lático, resultando na menor quantidade de perdas na fermentação (McDonald \& Henderson, 1981). Assim sendo, acelerando o processo de fermentação com o aumento da produção de ácido lático e a rápida queda do $\mathrm{pH}$, poderia resultar em menor perda de nutrientes, maior estabilização da silagem após a abertura do silo e em produção de silagem com maior qualidade (Lavezzo, 1993; Bolsen,1995). 
Os inoculantes bacterianos abrangem a classe de aditivos com mais rápido desenvolvimento e adoção em todo mundo, e sua eficiência depende da quantidade de carboidratos solúveis, poder tampão, da quantidade e qualidade dos microrganismos adicionados à cultura e principalmente da quantidade de bactérias pré-existentes na cultura (Vilela, 1998; Muck \& Kung, 1997; Seaglar, 1997). Weinberg \& Muck (1996) caracterizaram um inoculante desejável como sendo biologicamente competitivo, que apresente elevada taxa de crescimento na silagem, ser homofermentativo, produzir máxima quantidade de ácido lático num curto período de tempo, ser tolerante a presença de ácidos, capaz de crescer sob elevados teores de matéria seca (MS) e temperaturas, estendendose aos $50^{\circ} \mathrm{C}$.

Tem-se obtido maior sucesso com inoculantes aplicados na ensilagem de capins e leguminosas que na ensilagem do milho e do sorgo, possivelmente pela maior população inicial de microrganismos epifíticos presentes tanto em milho quanto em sorgo. Na revisão de Muck (1993), os inoculantes foram menos eficientes em melhorar a fermentação na silagem de milho (40\% dos casos), que na alfafa ( $75 \%$ dos casos) ou em capins ( $71 \%$ dos casos), sendo que a falta de resposta da ação dos aditivos bacterianos têm sido atribuída æ̀̀ características da forrageira a ser ensilada.

Os subprodutos associados àfermentação da silagem estão mais relacionados com o consumo voluntário pelo animal que a digestibilidade da matéria seca. Neste sentido, vários aditivos são comercializados com o propósito de controlar a fermentação e estimular o consumo da silagem (Vilela, 1998). Segundo Weiss (1996), os aditivos são usados para diminuir as perdas no processo de fermentação e aumentar o valor nutritivo da silagem.

Bergamaschine et al. (2000) estudaram o efeito da adição de resíduo de milho $(0,5$ e 10\%) na presença ou ausência de cultura bacteriana sobre a qualidade da silagem de capim Panicum maximum cv. tanzânia, e observaram que a cultura enzimo-bacteriana não melhorou a qualidade da silagem produzida, enquanto que a adição do resíduo do milho elevou os teores de MS, 
PB e digestibilidade "in situ" da MS, além de provocar decréscimo no $\mathrm{pH}$, e nos teores de FDN, FDA e N-NH .

Segundo O'Kiely et al. (1999), muitas das publicações presentes na literatura, que reportam resultados positivos do uso de inoculantes bacterianos, foram baseados na utilização de forragens de baixa qualidade ou em processos de ensilagem insatisfatórios. Sob tais condições, a população epifítica da forragem original é reduzida, criando assim a oportunidade para a manifestação de incrementos devido a inoculação com bactérias exógenas, que são reconhecidamente mais competitivas sob condições adversas, como por exemplo, a alta temperatura da massa. Nesses experimentos, a promoção de um aumento na concentração de bactérias láticas homofermentativas, frequentemente aumenta a taxa de acúmulo de ácido lático e isso deveria promover a queda do $\mathrm{pH}$. Contudo, o efeito no $\mathrm{pH}$ final ou na concentração do $\mathrm{N}$-amoniacal não são consistentes, apesar do fato de alguns resultados mostrarem uma pequena queda no $\mathrm{pH}$ e na concentração de $\mathrm{N}$-amoniacal. Em geral, o maior consumo voluntário de silagem e melhor desempenho dos animais, é condicionado à ocorrência de benefícios dos parâmetros de fermentação da silagem.

Quando o manejo da forragem e do processo de ensilagem é satisfatório, a presença de ácido lático na massa ocorre naturalmente, mesmo na ausência de inoculantes bacterianos. Em uma revisão realizada por Muck \& Kung (1997), onde sumarizaram dados com experimentos com inoculantes bacterianos entre 1990 e 1995, verificaram que em 60\% dos casos houve um menor pH e maior fermentação lática (221 experimentos); também em similar porcentagem houve menor nível de amônia, mostrando melhor preservação de proteína (148 experimentos). Em aproximadamente $30 \%$ dos casos houve aumento de cinco unidades percentuais na digestibilidade da matéria seca (82 experimentos); e em menos de $30 \%$ dos casos ocorreu melhora na estabilidade aeróbica (39 experimentos). Nessa mesma revisão, obtiveram valores percentuais relacionados a resposta de animais, de $28 \%$ de acréscimo no consumo (67 
experimentos), de $53 \%$ de aumento no ganho de peso (15 experimentos) e $47 \%$ de elevação da produção de leite (36 experimentos). Dessa forma, os autores concluíram que o uso de inoculantes bacterianos mostram respostas variáveis, nem sempre obtendo sucesso na sua aplicação.

Winters et al. (2001) realizaram um experimento de avaliação do desempenho de novilhos da raça Charolês recebendo silagem de azevém, com e sem inoculante bacteriano. Todas as silagens apresentaram boas caracteristicas fermentativas ( $\mathrm{pH}<4,0$ e $\mathrm{N}$-amoniacal $<5 \%$ ), entretanto houve maior consumo e maior ganho de peso no tratamento com a silagem inoculada. Os autores discutem que esse fato pode ter sido resultante do melhor balanço de amino ácidos dessas silagens, visto que o inoculante bacteriano inibiram o catabolismo de amino-ácidos durante a ensilagem, verificado pela análise química do efluente.

\subsection{Estabilidade sob aerobiose}

A perda de nutrientes da silagem durante a exposição do painel no silo, a retirada e fornecimento para o animal, bem como a exposição ao ambiente aeróbico no cocho, é muito significativa. Ranjit \& Kung Jr. (2000) demostram que quando as silagens são expostas ao ar, microrganismos oportunistas iniciam atividade metabólica, produzindo calor e consumindo nutrientes, resultando em perdas, as quais, segundo McDonald et al. (1991), podem chegar a $15 \%$. A resistência ao aumento da temperatura da silagem no painel do silo e durante a oferta ao animal no cocho, é denominada como estabilidade aeróbica. Balsalobre et al. (2001), menciona que a estabilidade aeróbica pode ser mensurada como o tempo gasto para que a temperatura da massa de silagem exposta ao ambiente, ultrapasse em $2^{0} \mathrm{C}$ em relação a variação da temperatura ambiente. Keady \& O'Kiely (1996) sugerem outra metodologia, na qual recomendam a diferença acumulada entre a temperatura da silagem e a 
temperatura ambiente por cinco dias após abertura do silo. Alguns trabalhos na literatura mostram uma menor estabilidade aeróbica para silagens aditivadas com inoculantes bacterianos de cepas homofermentativas, em relação a testemunha. Keady \& Steen (1995), trabalhando com silagem de azevém, e Veiga et al. (2000), trabalhando com silagem de Tanzânia, confirmam essa tendência. Nesse último trabalho foi observada menor estabilidade para silagens aditivadas com $10 \%$ de polpa cítrica, o que sugere que houve um maior concentração de carboidratos solúveis residuais.

Muck \& Kung (1997) discutem sobre a estabilidade aeróbica da silagem aditivadas com inoculantes bacterianos, destacando que a estabilidade aeróbica é afetada pelo $\mathrm{pH}$ e pelo ácido predominante produzido durante a fermentação da silagem. $\mathrm{O}$ pH mais baixo produzido por um inoculante deveria melhorar a vida útil da silagem, no entanto a maior concentração de ácido lático, predominante em silagem decorrentes da fermentação desejável, parece ser menos inibitório que o ácido acético às leveduras e bolores, causadores do aquecimentos e perdas. Concordando, Weinberg \& Muck (1996) e Filya et al. (2000), inferem que o uso de inoculantes bacterianos com cepas de bactérias homofermentativas podem diminuir a estabilidade aeróbica da silagem, visto a maior concentração de ácido lático em detrimento de ácido acético e propiônico. Kung (2000), explica que a maior concentração de ácido lático na silagem inoculada é o motivo da menor estabilidade aeróbica, devido ao fato que os microrganismos utilizam esse substrato após abertura do silo, gerando $\mathrm{CO}_{2}$, etanol e ácido acético, além de grande quantidade de calor. Assim, em sua revisão, Kung (2000), destaca a sugestão de outros autores, em se uitilizar de inoculantes contendo bactérias heterofermentativas, com a possibilidade de melhorar a estabilidade aeróbica de silagens, elevando o teor de ácidos acético.

Ranjit \& Kung (2000) realizaram um experimento com a inoculação de silagem de milho com cepas de LAB homofermentativas (L. plantarum), e homofermentativas mais heterofermentativas (L. buchneri), e concluiram que para essa silagem, a adição de cepas de L. buchneri, determinou a melhor 
estabilidade aeróbica. Nesse mesmo trabalho, os autores discutem que a recuperação de matéria seca pode ser menor em silagens tratadas com bactérias heteroláticas, contudo, a melhora na estabilidade aeróbica e no desempenho de animais, poderia compensar essas perdas potenciais durante a fermentação.

Filya et al. (2000) testando o uso de dois inoculantes LAB, uma homofermentativa e outra heterofermentativa, não verificaram diferenças quanto a estabilidade aeróbica da silagem quando a forragem foi ensilada fresca. Contudo, quando a forragem foi pré-emurchecida, houve uma melhoria na estabilidade aeróbica para o inoculante heterofermentativo, sendo que além de produzir mais ácido acético, essa cepa de bactéria (L. pentosus), comportou-se como osmo-tolerante e capaz de sobreviver em condições de baixa umidade, além de utilizar de pentoses (hemicelulose) no seu metabolismo. 


\section{MATERIAL E MÉTODOS}

\subsection{Experimento 1.}

Levantamento de índices técnicos associados àprodução de silagens de gramíneas tropicais.

\subsubsection{Objetivos}

Com o intuito de realizar uma descrição do perfil de produção de silagens de gramíneas tropicais, com ênfase em capins do gênero Panicum sp., foram realizadas visitas técnicas a 14 propriedades localizadas no Sudeste e no Centro-oeste brasileiro, sendo tomadas informações sobre o sistema de produção de silagem de capim.

\subsubsection{Material e Métodos}

As informações a respeito dos índices produtivos e do manejo alimentar do rebanho foram tomadas junto ao técnico responsável da propriedade.

Após a remoção de uma camada superficial do painel do silo, a mensuração da densidade da silagem foi obtida através do corte de um cubo de $50 \mathrm{~cm}$ de aresta, posicionando no centro geométrico do panel. O corte do cubo foi realizado com o auxílio de uma moto-serra, e o material retirado do cubo foi submetido àpesagem e amostrado. 
A estimação do tamanho das partículas foi realizada segundo metodologia das peneiras do "PennState Particle Size Separator", proposto por Lammers (1996), definindo a percentagem de material de diâmetro superior à $1,905 \mathrm{~cm}$, intermediário de 1,905 à 0,787 cm, e inferior à $0,787 \mathrm{~cm}$.

$\mathrm{O}$ pH foi determinado com o uso de um potenciômetro digital (Digimed TE-902). O teor de matéria seca foi mensurado através da secagem do material durante 48 horas em estufa com ar forçado a $55^{\circ} \mathrm{C}$, após o descongelamento das amostras.

A determinação da condutividade elétrica $(C E)$ foi realizada segundo metodologia proposta por Kraus et al (1996), com a utilização de um condutivímetro $\left(\mu \mathrm{S} . \mathrm{cm}^{-1}\right)$.

Os dados originados das unidades de produção visitadas foram agrupados para obtenção de tendências e dispersão, sendo submetidos à procedimentos de estatística descritiva.

\subsection{Experimento}

O experimento foi conduzido no Departamento de Produção Animal Setor de Ruminantes, na ESALQ - USP, Piracicaba (SP).

A forragem Panicum maximum Jacq., cv Tanzânia, foi colhida em uma gleba destinada a produção de silagem, com cerca de 8 ha, localizada em um solo caracterizado como latosolo roxo eutrófico, cuja a composição química é apresentada no Quadro 1. 
Quadro 1. Análise química do solo da gleba experimental.

\begin{tabular}{|c|c|c|c|c|c|c|c|c|}
\hline $\mathrm{pH}$ & $\mathrm{MO}$ & $P$ & $\mathrm{~K}$ & $\mathrm{Ca}$ & $\mathrm{Mg}$ & $\mathrm{H}+\mathrm{Al}$ & $T$ & $\mathrm{~V}$ \\
\hline $\mathrm{CaCl}_{2}$ & g.dm ${ }^{-3}$ & $\mathrm{mg} \cdot \mathrm{dm}^{-3}$ & \multicolumn{5}{|c|}{ Mmol.dm ${ }^{-3}$} & $\%$ \\
\hline 4,9 & 29 & 36 & 6,6 & 60 & 23 & 52 & 141 & 63 \\
\hline
\end{tabular}

Em seu segundo ano de corte, foram realizadas as devidas correções nas propriedades químicas do solo e fornecimento de nutrientes afim de proporcionar um dossel com produtividade e valor nutritivo adequados ao nível de exploração proposto.

Para tanto foi efetuada aplicação de 2,0 tha ${ }^{-1}$ de calcáreo dolomítico (76\%PRNT), durante o mês de junho de 2000. Com o objetivo de repor os nutrientes recrutados com a extração da forragem colhida, foram aplicados $1200 \mathrm{~kg} \cdot \mathrm{ha}^{-1}$ da fórmula 20-00-20 e $1000 \mathrm{~kg} \cdot \mathrm{ha}^{-1}$ de sulfato de amônio durante o ano agrícola 2000/2001. Desses, foi aplicada uma dose de $600 \mathrm{~kg}^{\mathrm{ha}}{ }^{-1} \mathrm{da}$ fórmula 20-00-20, em final de Dezembro de 2000, logo após o corte de rebaixamento da forragem, antecipando o crescimento da forragem utilizada no experimento.

O corte de inverno foi realizado no dia 17 de julho de 2000 (70 dias de crescimento vegetativo), e o corte de verão no dia 11 de fevereiro de 2001 (45 dias crescimento vegetativo). Entre esses dois cortes, ocorreu uma colheita no mês de dezembro, para fins de utilização para os animais do rebanho do Departamento de Produção Animal.

A forragem colhida em cada estação do ano (verão ou inverno), foi submetida à combinação dos seguintes fatores: alteração do teor de matéria seca, alteração do tamanho médio das partículas, e aplicação de inoculante bacteriano.

Fator 1. Alteração do teor de matéria seca da planta (TMS)

Níveis do fator 1: matéria seca original (MO); pré-emurchecimento (PE); e matéria seca original sob adição de polpa cítrica peletizada (MOPC). 
Fator 2. Alteração do tamanho médio das partículas.

Níveis do fator 2. maior distanciamento alcançado na regulagem da contra faca, partícula maior (PMa); menor distanciamento alcançado na regulagem da contra faca, partícula menor (PMe).

Fator 3: Aplicação de inoculante bacteriano

Níveis do fator 3: presença do inoculante (C); ausência do inoculante (A).

O ensaio foi realizado seguindo um delineamento inteiramente casualizado, sob o arranjo de parcelas subdivididas (split-plot). Os tratamentos corresponderam a combinações das formas de alteração do teor de matéria seca da forragem pré-ensilagem (três); dos tamanhos de partículas (dois) e da presença de inoculante bacteriano (dois), que foram alocados æ̀s parcela. As colheitas, ocorridas em duas estações do ano (inverno e verão), foram consideradas na subparcela. Sob esse arranjo foram gerados 12 tratamentos, avaliados com 4 repetições cada, aplicadas às estações do ano (inverno ou verão).

\subsubsection{Corte, colheita e picagem}

A colheita foi realizada com a colhedora marca Siltomac modelo 775 , sendo seguidas as recomendações técnicas do operador e técnico disponibilizado pela empresa Siltomac, os quais acompanharam a colheita do capim durante os dois cortes (inverno e verão).

A picagem foi obtida sob dois tamanhos de partículas, procurando uma amplitude máxima entre eles. A regulagem foi efetuada no distanciamento da contra-faca, determinando o maior e menor tamanho de partícula possível. 


\subsubsection{Perdas no campo}

A estimação da eficiência de colheita mecânica foi realizada através de mensurações conforme descrito abaixo, considerado os tratamentos contendo a umidade original da forragem, obtida pelo corte direto, e o submetido ao préemurchecimento. A metodologia de amostragem quantitativa da massa de forragem foi realizada segundo discutido por Penati et al. (2001), os quais trabalharam com diferentes dimensões de amostragem $\left(0,25,1,0\right.$ e 2,0 $\mathrm{m}^{2}$; quadrado e retângulo) e vários números de repetições (1 a 9 ) na estimação da massa de forragem de pastagem de capim Tanzânia (Panicum maximum, Jacq. cv Tanzânia), e verificaram que ao utilizar-se de quadrados de $1 \mathrm{~m}^{2}$ com 4 repetições, promoveu-se um menor coeficiente de variação e alta eficiência na estimação da massa de forragem.

O procedimento realizado na mensurações no tratamento com o préemurchecimento da forragem:

- A massa de forragem total foi mensurada pelo método de quadrados de 1 $\mathrm{m}^{2}$, lançados aleatoriamente na área destinada a colheita da forragem na gleba experimental, sendo realizada a colheita de toda a forragem verde e o material morto depositado sobre o solo delimitado pelo quadrado;

- A colhedora marca Siltomac modelo 775 foi ajustada para iniciar o corte da forragem, mantida aberta a janela de manutenção traseira. Com isso, a forragem captada pelo conjunto de facas moveis, posicionadas na barra frontal, não foi submetida a picagem pelas facas do rotor, sendo então lançadas sobre a touceira, e permanecendo no campo para fins de desidratação. Os quadrados foram lançados e estimou se a forragem ceifada, o resíduo de touceira e material morto sobre o solo.

- Após aproximadamente 6 horas de secagem a forragem foi recolhida pelo mesmo equipamento mencionado, sofrendo a picagem final pelas facas do rotor. Os quadrados foram lançados, sendo estimada a forragem ceifada e 
aquela não colhida, o resíduo de touceira e o material morto sobre o solo. Nessa oportunidade houve ligeira redução na altura de corte da colhedora, reduzindo a altura da touceira remanescente, em relação à colhida pelo corte direto. Esse procedimento fez-se necessário afim de diminuir as perdas no recolhimento da forragem

Procedimento realizado nas mensurações aplicadas ao tratamento com o corte direto da forragem:

- A massa de forragem total foi mensurada pelo método de quadrados de 1 $\mathrm{m}^{2}$, lançados aleatoriamente na área destinada a colheita da forragem no gleba experimental, sendo realizada a colheita de toda a forragem verde e o material morto depositado sobre o solo delimitado pelo quadrado.

- Corte e colheita da forragem foi efetuado com a colhedora marca Siltomac, modelo 775 . Os quadrados foram lançados novamente e estimou-se a forragem ceifada e não colhida (perdas na colheita), o resíduo de touceira e material morto sobre o solo.

3.2.3 Forragem com a matéria seca original (MO).

A forragem com a matéria seca original (MO), compreende o material colhido no campo através do corte direto, com a umidade original da forragem.

\subsubsection{Pré-emurchecimento}

O pré-emurchecimento da forragem constitui-se na ceifagem da forragem no campo e exposição ao ambiente para a desidratação. Em função de verificar a possibilidade de pré emurchecer e colher a forragem no mesmo dia, evitando 
maiores perdas de nutrientes e a reidratação do período noturno, determinou-se aproximadamente 6 horas de exposição à secagem da forragem. Com isso, 0 teor de matéria seca observado nesse tratamento é consequencia desse tempo de exposição imposto a forragem.

\subsubsection{Adição de polpa cítrica peletizada (PCP).}

Nos tratamentos com a adição de PCP, essa foi adicionada no momento prévio ao enchimento dos baldes, realizando uma perfeita homogeneização da PCP com a forragem colhida pelo corte direto. No corte de inverno, a dose adicionada foi de $5 \mathrm{~kg}$ de PCP para cada $100 \mathrm{~kg}$ de forragem fresca, e no corte de verão, $15 \mathrm{~kg}$ de PCP para cada $100 \mathrm{~kg}$ de forragem fresca, visando com isso atingir-se aproximadamente o teor de matéria seca na mistura, semelhante daquele obtido sob efeito do pré-emurchecimento.

\subsubsection{Aplicação do inoculante bacteriano}

O inoculante bacteriano utilizado para a aplicação foi o ECOSIL ${ }^{\circledR}$ Silage Inoculant, da empresa ECOSYL Products Limited (número de registro na Inglaterra: 3155665), caracterizado como uma cepa de Lactobacillus plantarum, na forma pó desidratado, com nível de garantia de 20 bilhões de UFC.g ${ }^{-1}$ de produto.

A inoculação foi realizada segundo a recomendação técnica do fabricante do $E C O S I L ~{ }^{\circledR}$, com a adição de 100 bilhões UFC viáveis..$^{-1}$ de forragem fresca, sendo sua inoculação realizada imediatamente antes do enchimento dos silos experimentais, com a aplicação uniforme sobre a forragem. Tomou-se o cuidado de evitar contaminação do inoculante com a forragem não inoculada, através da separação de ferramentas, pessoal e 
momento do preparo das silagens. Para o preparo da solução contendo o inoculante, foi utilizada água bi-destilada mantida àtemperatura ambiente.

\subsection{Silos experimentais}

Para a confecção do silo experimental (unidade experimental), foram utilizados baldes plástico com 20 litros de capacidade, com tampas apropriadas para garantir a vedação adequada. No fundo do balde foram colocados $2 \mathrm{~kg}$ de areia seca, protegida com uma tela fina de plástico e 4 camadas de pano de queijo, afim de não ocasionar o contato da areia com a forragem, e realizar a medida quantitativa do efluente produzido. $\mathrm{Na}$ tampa do balde (silo experimental), foi confeccionada uma válvula de escape (tipo "bunsen") para escape dos gases produzidos, afim de que as perdas de matéria seca, devidas ao processo fermentativo, fossem quantificadas.

A forragem foi compactada com os pés, tomando-se como critério a acomodação de camadas de aproximadamente $10 \mathrm{~cm}$ de espessura, de forma que a pressão exercida em cada balde (silo experimental), fosse semelhante, e tornasse possível a observação de diferenças na densidade nos diferentes tratamentos, como resultado das características físicas do material ensilado.

Com a acomodação final da forragem, o silo experimental foi fechado com a tampa apropriada, e vedada com fitas plásticas auto-adesivas, na tentativa de evitar a entrada de ar no interior do balde. Em seguida, a massa dos baldes foi quantificada e esses armazenados em local protegido, mantido sob temperatura ambiente. 


\subsection{Abertura dos silos experimentais}

Decorridos 120 dias do fechamento, os silos experimentais foram abertos, seguindo o procedimento descrito a seguir:

Pesagem do balde: ao subtrair o peso original do balde após a vedação, do peso no momento da abertura, foi possível quantificar as perdas de matéria seca pelo escape de gases através da válvula tipo "Bunsen";

Amostragem: foi retirada uma amostra composta, para as análises de atividade de água ( $\mathrm{AW})$, condutividade elétrica $(\mathrm{CE})$, granulometria, extrato aquoso, poder tampão e pH, bromatologia (matéria seca, matéria mineral, FDN, FDA, Lignina, N-FDN, N-FDA, PB, EE).

Pesagem da silagem: pela diferença de quantidade de matéria seca entre a forragem colocada no silo experimental e a silagem retirada, obteve-se a taxa de recuperação de matéria seca da fermentação.

Pesagem da areia: após retirar toda a silagem, a areia no fundo do balde foi quantificada, e subtraído do peso original, estimou a produção de efluente.

As amostras para as análises de atividade de água (AW), e condutividade elétrica $(C E)$, foram resfriadas, afim que não ocorresse líse das células da planta. As amostras destinadas a determinação de granulometria, extrato aquoso, poder tampão, $\mathrm{pH}$, e bromatologia, foram congeladas. Para a tomada de amostra da silagem, foi retirada uma aliquota originada da porção central do silo, na tentativa de representar o centro geométrico desse volume, desprezando as áreas contaminadas por fungos, bolores e leveduras. 


\subsection{Análises realizadas}

\subsubsection{Atividade de água (AW)}

As determinações de AW foram realizadas no Laboratório de Fungos Toxicogênicos e Micotoxinas (Depto. de Microbiologia, Instituto de Ciências Biomédicas, USP), através do uso do aparelho AQUALAB $\mathrm{CX}_{2}$, da marca Decagon Devices, Inc. Pullman, Washington, USA.

\subsubsection{Condutividade elétrica (CE)}

A determinação das perdas de conteúdo intracelular resultantes das diferenças no tamanho das partículas obtidas no corte da forragem, foi realizada através da mensuração da condutividade elétrica (CE) (Pauly, 1999). O método é baseado na mensuração indireta da quantidade de líquido intracelular liberado pela picagem do material e consequente rupturas de membrana celular, resultando na avaliação dos eletrólitos dispersos em solução, originados do fluído celular extravasado pelo rompimento de tecido vegetal. A medição foi realizada segundo proposta de Kraus et al. (1997), onde a forragem é agitada com água deionizada e filtrada, e a solução resultante submetida a leitura em $\mu \mathrm{S} . \mathrm{cm}^{-1}$, por um condutivímetro.

\subsubsection{Poder Tampão e pH}

Após o descongelamento, foi realizada a medição do $\mathrm{pH}$ com o uso de um potenciômetro digital (Digimed TE-902), e em seguida a determinação do poder tampão (Playne \& McDonald, 1966). 


\subsubsection{N-amoniacal $\left(\mathrm{N}-\mathrm{NH}_{3}\right)$}

$\mathrm{O} \mathrm{N}-\mathrm{NH}_{3}$ foi mensurado de acordo com o método colorimetrico descrito por Chaney \& Marbach (1962) e adaptado para ser utilizado em placas de microtítulo e posterior leitura em equipamento do tipo Elisa Reader (absorbância de 550 nanômetros).

\subsubsection{Bromatologia (MS, MM, PB, EE, FDN, FDA, N-FDN, N-FDA, Lignina)}

As amostras após o descongelamento à sombra, foram submetidas em estufas sob ar forçado para determinação da matéria seca a $55^{\circ} \mathrm{C}$ e em seguida a secagem foram moídas contra peneira de $1 \mathrm{~mm}$, para posterior determinação da matéria seca a $105^{\circ} \mathrm{C}$. A matéria mineral foi obtida com a queima na mufla à $600^{\circ} \mathrm{C}$ por 3 horas. A determinação de $\mathrm{PB}$ foi obtida através da combustão da amostra segundo o método de Dumas, utilizando-se um autoanalisador de nitrogênio, da marca LECO, modelo FP-528 (Wiles et al., 1998). A determinação do EE seguiu a metodologia da AOAC (1990). As análises de FDA, FDN, Lignina foram realizadas através do método sequencial proposto pela ANKOM Fiber Analyser (ANKOM Technology Corporation, Fairport, NY), citados por Holden (1999). O N-FDN e o N-FDA foi mensurado conforme metodologia proposta por Krishnamoorthy et al. (1982).

\subsubsection{Granulometria das partículas}

A estimação do tamanho das partículas nos diferentes tratamentos foi realizada com base na metodologia da estratificação em peneiras utilizando o "PennState Particle Size Separator" (Lammers, 1996), definindo a proporção de 
material retido com diâmetro superior à1,905 cm, intermediário à 1,905 - 0,787 $\mathrm{cm}$, e inferior à $0,787 \mathrm{~cm}$.

\subsubsection{Estabilidade aeróbica}

A medida da estabilidade aeróbica da silagem foi realizada através da manutenção de uma alíquota de silagem não compactada em um balde sem tampa e coberto com um pano de queijo, após abertura dos baldes, em duas repetições por tratamento. Um termômetro foi posicionado no centro geométrico no interior da massa de silagem, e os baldes permaneceram em ambientes fechados afim de evitar-se a variação da temperatura ambiente. Foram tomadas 3 medidas diárias de temperatura em cada silo e no ambiente, às 8:00, 14:00 e 20:00 horas, durante 20 dias após a abertura dos silos.

\subsubsection{Cálculo da energia da silagem}

A densidade energética dos diferentes tratamentos, foram determinadas segundo modelo descrito no NRC (2001).

O primeiro passo na predição do valor energético usando o modelo sugerido é a determinação da quantidade de nutrientes digestíveis provenientes de cada nutriente. O segundo passo é a somatória da quantidade de nutrientes digestíveis na MS e subtração da energia metabólica fecal. A equação proposta para o cálculo de NDT de forragens é a seguinte:

$$
\begin{aligned}
& \text { NDT }=\mathrm{PB} \times \mathrm{e}^{-0,12 \times \text { nida }}+0,98 \times\left(100-\mathrm{FDN}_{\mathrm{PB}}-\mathrm{EE}-\mathrm{PB}-\text { cinzas }\right)+ \\
& 2,25 \times(\mathrm{EE}-1)+0,75 \times\left(\mathrm{FDN}_{\mathrm{PB}}-\mathrm{L}\right) \times\left(1-\left[\left(\mathrm{L} / \mathrm{FDN} \mathrm{PB}^{0,667}\right]-7\right.\right. \\
& \text { NDT: nutrientes digestíveis totais; } \\
& \text { PB: proteína bruta; }
\end{aligned}
$$


$F_{P D}$ : FDN livre de proteína bruta;

EE : extrato etéreo;

$\mathrm{L}$ : lignina;

NIDA: NFDA.N total $^{-1}$.

\subsection{Análise estatística}

Os dados foram analisados segundo o procedimento MIXED do pacote estatísitco do SAS (Statistical Analysis System), versão 6.12 para Windows. Ao considerar o arranjo em parcelas subdivididas (split-plot), as principais causas de variação foram atribuídas à parcela (alteração do teor de matéria seca, tamanho de partícula, e inoculante bacteriano), assim como os efeitos de suas interações. A estação do ano (EST), representada por colheitas ocorridas no inverno ou no verão, por caracterizar uma tendência temporal, foi atribuída a sub-parcela, bem como as interações com as demais causas de variação. A composição do quadro de análise de variância com as causas de variação e graus de liberdade estão apresentados no Anexo A.

Utilizou-se o teste Tukey para a comparação de médias entre causas de variação, adotando-se 5\% como nível de significância. Quando necessária, a exploração das tendências, foi acompanhada da declaração do nível de significância observado. 


\section{RESULTADOS E DISCUSSÃO}

\subsection{Exprimento 1}

Através da análise do Anexo B, verifica-se que foram visitadas fazendas com diferentes sistemas de produção, com rebanhos variando de 30 a 40000 cabeças, sendo alimentadas com silagem de capim, e com produção de matéria seca por hectare por corte (t de $M S . h a^{-1}$.corte ${ }^{-1}$ ) variando de 2,7 a 8,1. Assim visualiza-se o grande universo de produção e exploração, destacando a grande amplitude de alternativas na utilização de silagens de gramíneas na alimentação de ruminantes.

Os dados indicam a adoção de alternativas como o uso de inoculante bacteriano e de polpa cítrica pelos produtores e técnicos, sendo que das 14 propriedades, 3 utilizaram PCP (6 à 8\%), e 6 propriedades fizeram uso da inoculação bacteriana.

Dos dados do Anexo $B$, também depreende-se que a produtividade média de $17 \mathrm{t}$ de $\mathrm{MS}$.ha ${ }^{-1}$. ano ${ }^{-1}$ é significativamente inferior ao potencial da cultura, e que algumas propriedades apresentam produtividade semelhante àquelas que utilizam-se de culturas anuais, gerando o questionamento sobre a justificativa em explorar capins tropicais perenes para silagens, sob tais condições. Em geral as dificuldades encontradas no manejo da ensilagem durante o período de incidência de chuvas no verão, respondem parcialmente pela perda de produtividade. 
A Anexo $\mathrm{C}$ apresenta valores de teor de matéria seca, $\mathrm{pH}$, distribuição do tamanho de partícula, condutividade elétrica e densidade da silagem, bem como a identificação da colhedora utilizada. Também verifica-se a grande amplitude desses parâmetros nas diferentes propriedades, revelando a variação de eficiência no processo de ensilagem. Obteve-se valor médio pH de 4,92, considerado elevado segundo McDonald et al. (1991) e Vilela (1998), evidenciando a relativa dificuldade dos produtores em alcançar valores de $\mathrm{pH}$ nos limites recomendados (3,8 à 4,2). A Figura 1 ilustra a porcentagem de silagem contendo $\mathrm{pH}$ acima do recomendável, verificando que apenas $14 \%$ das propriedades visitadas apresentam silagens com pH abaixo de 4,2.

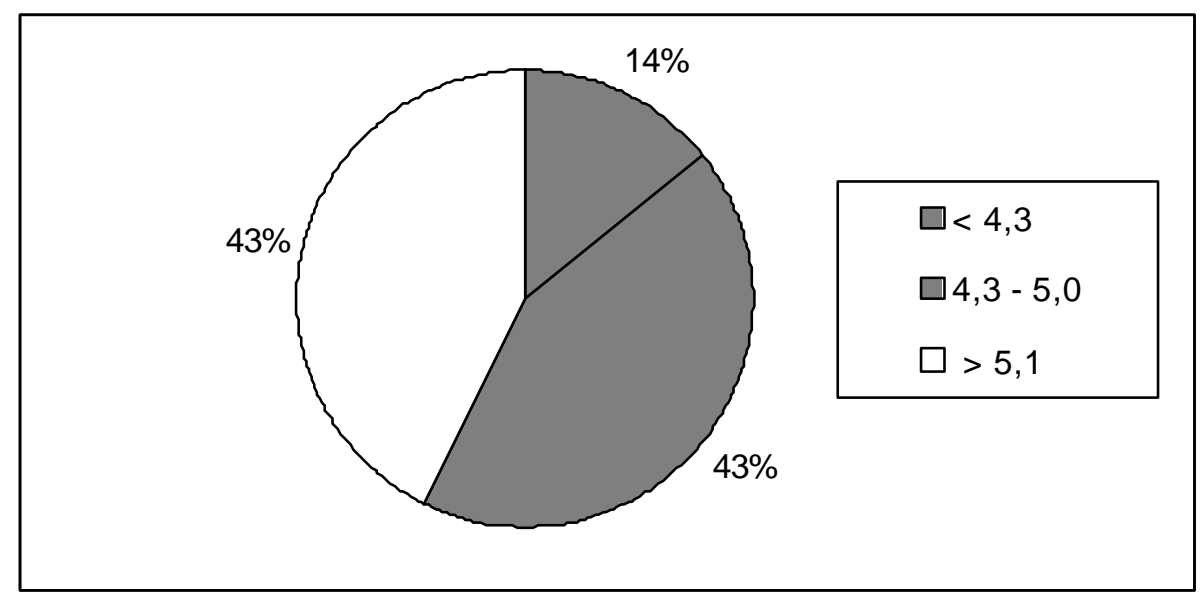

Figura 1 - Distribuição das propriedades visitadas em relação ao valor de pH das silagens de capim.

Com relação aos parâmetros físicos, verifica-se na Figura 2 a menor eficiência na compactação da silagem, tendo apenas 7\% das propriedades atingiram valores de densidade dentro da amplitude recomendada por Holmes \& Muck (1999), que mencionam o valor de limite mínimo de $225 \mathrm{~kg} \cdot \mathrm{MSm}^{-3}$. 


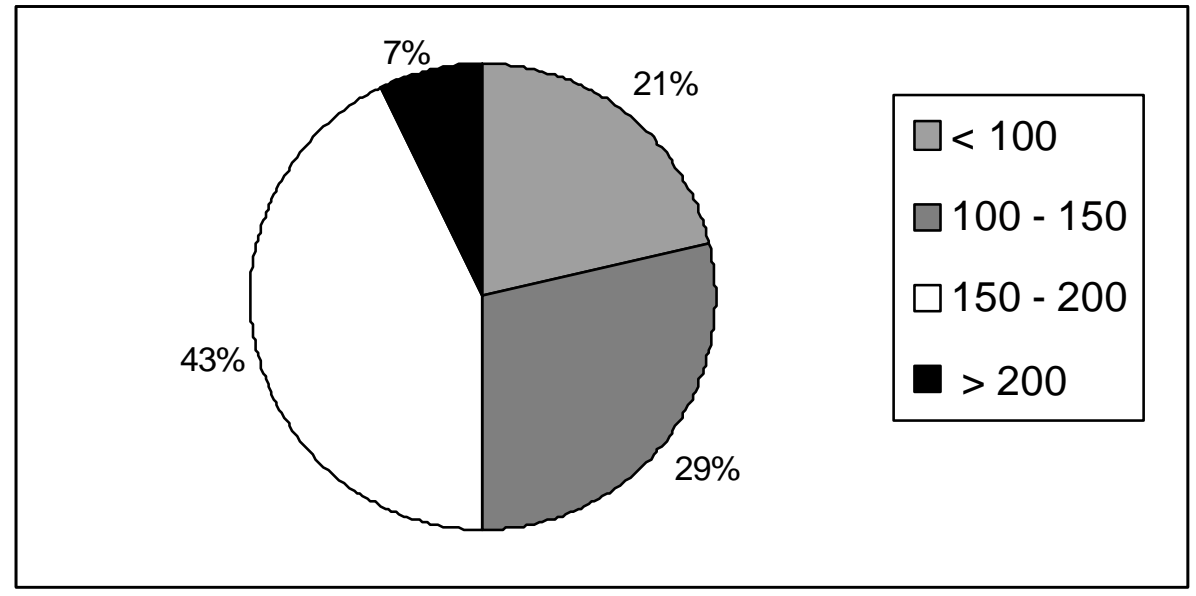

Figura 2 - Distribuição das propriedades visitadas em relação ao valor da densidade $\left(\mathrm{tMS} . \mathrm{m}^{-3}\right)$ das silagens de capim.

Na Figura 3 observa-se a representação gráfica da distribuição entre tamanho de partícula e a condutividade elétrica, onde a redução no tamanho de partículas tendeu a promover maiores valores de CE, conforme verificado por Shinners et al. (2000), com silagem de alfafa. Vale ressaltar, que a amostragem foi realizada em diferentes propriedades, implicando em diferentes condições de solo, de adubação e estágio fisiológico de colheita da planta, o que ocasionou grande amplitude no teor de minerais nas amostras, resultando em $R^{2}$ da curva considerado insatisfatório para o estabelecimento de relação funcional.

Ausência de relação entre tamanho de partícula e CE também poderia ser atribuída a participação de colhedoras oriundas de concepção de tecnologia muito diversa. Ao observar os valores do Anexo $\mathrm{C}$ e a figura 3 , verifica-se que a amplitude de variação no tamanho de partículanão foi acompanhada pela condutividade elétrica, sugerindo que o corte realizado por colhedoras de precisão, possa conciliar redução no tamanho de partícula e pouca elevação no 
extravasamento de conteúdo celular, conforme fora observado por Aguiar et al. (2001).

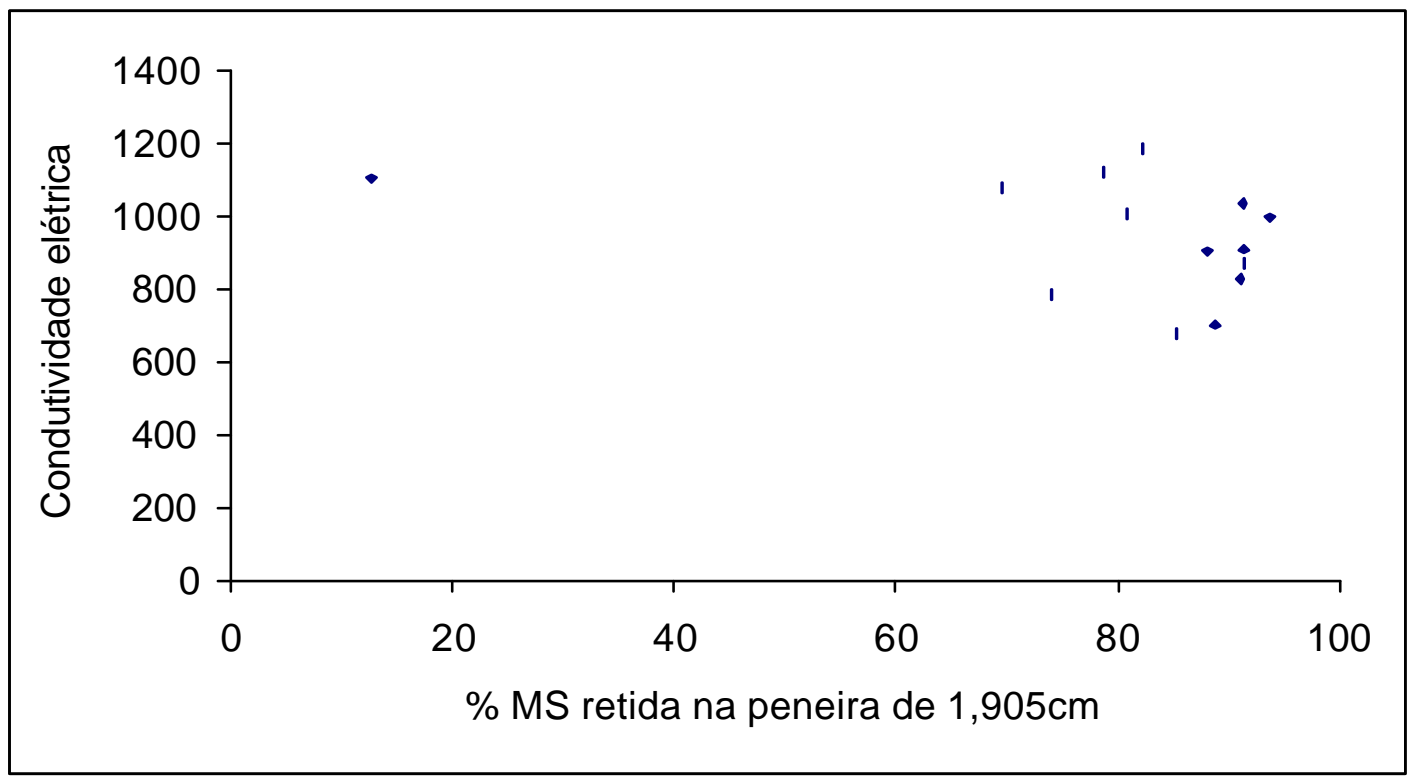

Figura 3 - Representação gráfica da distribuição da condutividade elétrica (ì S.cm ${ }^{-1}$ ), em função do tamanho de partícula (\% retida na peneira de 1,905 $\mathrm{cm})$, das silagens de gramíneas coletadas nas propriedades.

Esses dados fornecem a informação de que os equipamentos de corte e colheita utilizados nas propriedades, determinam um tamanho de partícula acima da expectativa, e quando comparados com a colhedora Case 7400, apresentam significativo diferencial de porcentagem de partículas retidas na peneira de 1,905 cm. A colhedora Case 7400 proporcionou retenção de 12\% na peneira de 1,905 cm, enquanto que as demais colhedoras jamais apresentaram valores inferiores a 69,5\%. Esse determinou alteração nas densidades das silagens, que com a exceção daquela originada da operação da colhedora Case 7400, todas as demais caracterizaram valores de densidade inferiores aos recomendados por Holmes \& Muck (1999), que citam o valor de limite mínimo 
de $225 \mathrm{~kg} \mathrm{MS} . \mathrm{m}^{-3}$, para que a densidade de compactação não seja restritiva na obtenção de uma silagem de qualidade satisfatória. Assim, na Figura 4, verificase a tendência de se obter valores superiores de densidade a medida que a tamanho de partícula é reduzido, representado pela percentagem de partículas retidas na peneira de $1,905 \mathrm{~cm}$.

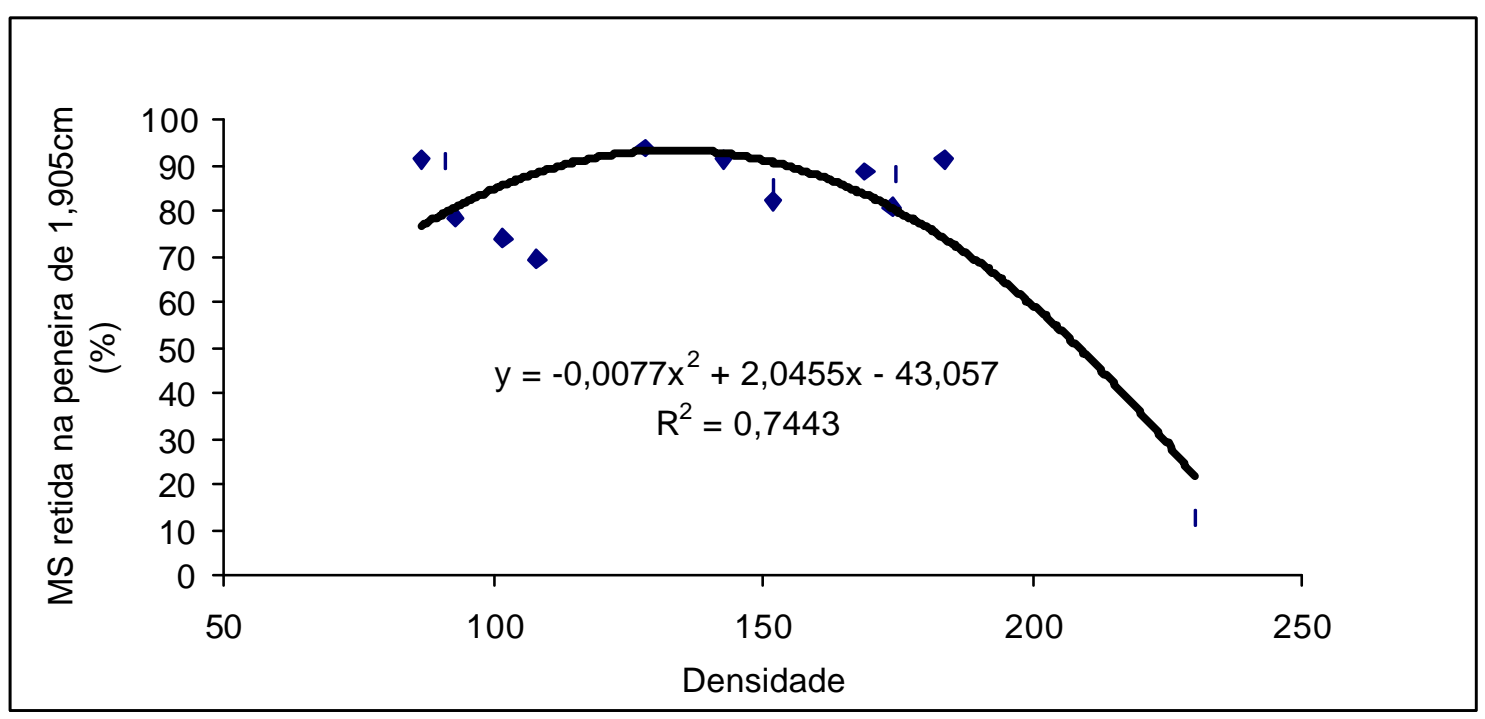

Figura 4 - Relação entre e a densidade da silagem $\left(\mathrm{kgMS} \cdot \mathrm{m}^{-3}\right)$, o tamanho de partícula (\% MS retida na peneira de 1,905 cm) das silagens de gramíneas coletadas nas visitas técnicas.

A metodologia de caracterização do tamanho de partículas proposto por Lammers et al. (1996), através da estratificação das partículas contra 3 peneiras com orifícios de diâmetros diferentes, mostrou-se não suficientes para estratificar a forragem picada de forma a evidenciar diferenças entre as colhedoras analizadas, uma vez que em média $79,9 \%$ da amostra foi retida acima da peneira de maior diâmetro $(1,905 \mathrm{~cm})$. 


\subsection{Experimento 2}

Em reconhecimento à magnitude do efeito das estações do ano (EST) inverno e verão, sobre as variáveis dependentes analisadas, optou-se pela apresentação dos resultados, individualizando cada estação. Os valores dos coeficientes de variação dos parâmetros avaliados estão apresentados nos Anexos $\mathrm{Hel}$.

\subsubsection{Composição bromatológica da forragem na ensilagem.}

A análise bromatológica da amostra de forragem coletada no momento da ensilagem, está apresentada na Tabela 4, referente aos dois períodos (inverno e verão), e aos tratamentos impostos.

Com relação a composição bromatológica da forragem no dois períodos, nota-se que o capim oriundo do corte de verão, com 45 dias de crescimento vegetativo, apresentou maior teor de proteína bruta (PB), porém com baixos teores de matéria seca (MS) e de fibra detergente neutro (FDN), dentro do comparativo com o capim de inverno, o qual estava com 70 dias de crescimento vegetativo. Essa diferença se deve, provavelmente a estacionalidade de produção, característica do período de inverno, cuja a interferência está relacionada com a temperatura ambiente, precipitação e fotoperíodo, os quais atuam diretamente sobre o valor qualitativo das forragens, em especial as gramíneas do gênero Panicum sp. Quanto aos demais parâmetros analisados (fibra detergente ácido (FDA), lignina, extrato etéreo (EE), matéria mineral (MM) e nutrientes digestíveis totais (NDT)), apresentaram similaridade tanto no inverno quanto no verão.

A inclusão de polpa cítrica peletizada (PCP), no inverno na taxa de $5 \mathrm{~kg}$ de PCP para $100 \mathrm{~kg}$ de forragem fresca, e no verão, $15 \mathrm{~kg}$ de PCP para $100 \mathrm{~kg}$ 
de forragem fresca, promoveu aumento no teor de MS e nos teores de carboidratos não fibrosos (CNF). Isso é devido a alta concentração de pectina desse aditivo, provocando o efeito indireto na diminuição da fração fibrosa, e aumentando o NDT do material a ser ensilado.

No corte de verão, o teor de matéria seca do tratamento pré-emurchecido $(\mathrm{PE})$, foi inferior ao tratamento com adição de polpa cítrica peletizada (MOPC), sendo que no corte de inverno, foi verificado o efeito oposto. Entretanto, essa diferença não era almejada, sendo que os tratamentos com préemurchecimento (PE) e a adição de polpa cítrica (MOPC), deveriam ter valores similares em relação a MS. Contudo, no corte de inverno, devido a forragem conter teores elevados de matéria seca, associada com as características climáticas da data de corte (ensolarado e com umidade relativa de $44 \%$ ), seis horas de emurchecimento no campo ocasionaram uma maior elevação na MS em relação a adição de PCP (MOPC). Já no corte de verão, ocorreu o efeito contrário, sendo o dia parcialmente nublado e com alta umidade relativa $(68 \%)$, o período de emurchecimento não foi suficiente para elevar a MS a teor similar do tratamento MOPC (27\% de MS). 
Tabela 1. Médias do valor nutritivo da forragem e da silagem de capim Tanzânia colhidas durante o inverno.

\begin{tabular}{|c|c|c|c|c|c|c|c|c|c|c|c|c|c|c|c|}
\hline \multirow[b]{3}{*}{ Parametros } & \multicolumn{4}{|c|}{$\mathrm{MO}$} & \multicolumn{4}{|c|}{ MOPC } & \multicolumn{4}{|c|}{$\mathrm{PE}$} & \multirow{2}{*}{\multicolumn{3}{|c|}{ EFEITOS }} \\
\hline & \multicolumn{2}{|c|}{ PMe } & \multicolumn{2}{|c|}{ PMa } & \multicolumn{2}{|c|}{ PMe } & \multicolumn{2}{|c|}{$\mathrm{PMa}$} & \multicolumn{2}{|c|}{ PMe } & \multicolumn{2}{|c|}{$\mathrm{PMa}$} & & & \\
\hline & $C$ & $\mathrm{~S}$ & $C$ & $S$ & $C$ & $S$ & $\mathrm{C}$ & $S$ & C & $S$ & C & $S$ & TMS & PART & INOC \\
\hline \multicolumn{16}{|l|}{ Forragem } \\
\hline MS, \% & 29,5 & 29,3 & 30,0 & 30,1 & 32,5 & 32,5 & 33,2 & 33,3 & 36,8 & 37,2 & 38,2 & 38,5 & - & - & - \\
\hline $\mathrm{PB}, \% \mathrm{MS}$ & 5,9 & 5,8 & 6,1 & 6,3 & 5,9 & 6,1 & 6,3 & 6,1 & 5,8 & 5,6 & 5,8 & 5,7 & - & - & - \\
\hline CNF, \%MS & 16,3 & 15,0 & 16,9 & 19,8 & 22,4 & 26,8 & 27,5 & 28,2 & 18,4 & 14,8 & 17,3 & 13,8 & - & - & - \\
\hline FDN, \%MS & 67,7 & 69,2 & 66,7 & 64,8 & 63,1 & 59,3 & 58,1 & 57,9 & 67,7 & 69,5 & 70,2 & 72,7 & - & - & - \\
\hline FDA, \%MS & 42,0 & 41,9 & 43,3 & 41,6 & 32,1 & 30,4 & 31,0 & 28,3 & 33,8 & 37,2 & 39,4 & 43,0 & - & - & - \\
\hline Hem, \%MS & 25,7 & 27,3 & 23,4 & 23,2 & 31,0 & 28,9 & 27,1 & 29,7 & 33,9 & 32,4 & 30,8 & 29,7 & - & - & - \\
\hline Lig, \%MS & 4,3 & 4,3 & 4,9 & 5,0 & 4,0 & 4,1 & 4,1 & 4,1 & 4,3 & 5,2 & 4,8 & 5,4 & - & - & - \\
\hline N-FDN ${ }^{1}$ & 40,8 & 43,4 & 38,8 & 43,1 & 45,6 & 44,6 & 45.9 & 44.7 & 40,4 & 35,1 & 39.9 & 38,2 & ـ & - & - \\
\hline$N-F D A^{1}$ & 15,7 & 16,2 & 20,4 & 19,0 & 19,7 & 20,4 & 23,5 & 21,9 & 11,4 & 11,8 & 17,5 & 16,7 & - & - & - \\
\hline $\mathrm{B}^{1}$ & 25,1 & 27,3 & 18,4 & 24,1 & 25,9 & 24,2 & 22,4 & 22,8 & 29,0 & 23,4 & 22,4 & 21,5 & - & - & - \\
\hline MM, & 11,0 & 11,9 & 11,2 & 11,0 & 10,7 & 10,0 & 10,0 & 9,3 & 11,0 & 12,3 & 9,0 & 10,5 & - & - & - \\
\hline$E E, \% M S$ & 1,9 & 1,0 & 2,0 & 1,9 & 1,5 & 1,3 & 1,4 & 1,4 & 0,8 & 0,8 & 1,0 & 0,9 & - & - & - \\
\hline NDT, \%MS & 56,2 & 53,6 & 55,0 & 56,3 & 58,1 & 59,2 & 59,4 & 59,6 & 55,5 & 51,7 & 55,5 & 52,5 & - & - & - \\
\hline \multicolumn{16}{|l|}{ Silagem } \\
\hline$M S$ & $29,4^{\mathrm{a}}$ & $29,2^{\mathrm{a}}$ & $30,1^{\mathrm{a}}$ & $30,0^{\mathrm{a}}$ & $34,3^{b}$ & $34,1^{b}$ & $35,2^{\mathrm{bc}}$ & $35,2^{b c d}$ & $36,9^{\mathrm{de}}$ & $36,7^{\text {cde }}$ & $38,4^{\mathrm{e}}$ & $38,2^{\mathrm{e}}$ & ** & ** & 0,4 \\
\hline $\mathrm{PB}, \% \mathrm{MS}$ & $5,2^{\mathrm{ab}}$ & $6,4^{c}$ & $7,5^{\mathrm{de}}$ & $4,5^{\mathrm{ab}}$ & $5,3^{b}$ & $8,2^{\mathrm{e}}$ & $7,2^{c d}$ & $5,2^{a b}$ & $6,6^{c d}$ & $5,0^{\mathrm{ab}}$ & $6,9^{\mathrm{cd}}$ & $4,2^{\mathrm{a}}$ & * & 0,5 & \\
\hline CNF, \%MS & $16,5^{\mathrm{ab}}$ & $17,2^{\mathrm{abc}}$ & $14,5^{\mathrm{a}}$ & $17,2^{\mathrm{abc}}$ & $22,0^{\text {de }}$ & $21,1^{\mathrm{cd}}$ & $20,4^{b c d}$ & $26,5^{\mathrm{e}}$ & $16,4^{\mathrm{ab}}$ & $18,4^{\mathrm{abcd}}$ & $14,1^{\mathrm{a}}$ & $19,8^{\text {bcd }}$ & ** & 0,3 & 0,1 \\
\hline FDN, \%MS & $63,4^{\text {cd }}$ & $61,9^{b c d}$ & $63,6^{d}$ & $65,0^{d}$ & $59,4^{\mathrm{ab}}$ & $57,1^{\mathrm{a}}$ & $59,8^{\mathrm{abc}}$ & $56,1^{\mathrm{a}}$ & $62,2^{\mathrm{bcd}}$ & $62,2^{\text {bcd }}$ & $63,4^{\mathrm{cd}}$ & $63,2^{\text {cd }}$ & ** & 0,6 & 0,8 \\
\hline FDA. \%MS & $39,1^{\mathrm{cd}}$ & $38.6^{\mathrm{cd}}$ & $37.7^{\mathrm{bc}}$ & $38,4^{\mathrm{cd}}$ & $38,1^{b c d}$ & $35,7^{\mathrm{ab}}$ & $38,2^{b c d}$ & $34.7^{\mathrm{a}}$ & $38,4^{\text {cd }}$ & $40,4^{d}$ & $38,4^{\text {cd }}$ & $39.3^{\mathrm{cd}}$ & ** & 0.78 & 0.6 \\
\hline Hem, \%MS & $24,3^{\mathrm{abc}}$ & $23,2^{\mathrm{ab}}$ & $25,8^{b c}$ & $26,5^{\mathrm{c}}$ & $21,3^{a}$ & $23,5^{\mathrm{abc}}$ & $21,5^{\mathrm{a}}$ & $21,4^{\mathrm{a}}$ & $23,8^{a b c}$ & $21,8^{a}$ & $25,0^{\mathrm{abc}}$ & $23,8^{\mathrm{abc}}$ & ** & 0,5 & 0.8 \\
\hline Lig., \%MS & $4,3^{\mathrm{ab}}$ & $4,2^{a b}$ & $3,8^{\mathrm{a}}$ & $4,5^{\mathrm{abc}}$ & $4,0^{\mathrm{a}}$ & $3,9^{a}$ & $4,4^{\mathrm{ab}}$ & $4,3^{\mathrm{ab}}$ & $4,9^{b c}$ & $5,1^{\mathrm{C}}$ & $4,5^{\mathrm{abc}}$ & $4,7^{b c}$ & ** & * & 0,5 \\
\hline N-FDN ${ }^{1}$ & $39,0^{\text {cde }}$ & $41,5^{\mathrm{de}}$ & $35,6^{\mathrm{abcd}}$ & $29,7^{\mathrm{a}}$ & $35,7^{\mathrm{abcd}}$ & $38,6^{\text {bcde }}$ & $43,8^{\mathrm{e}}$ & $34,3^{\mathrm{abc}}$ & $36,4^{\mathrm{abcd}}$ & $31,9^{a b}$ & $39,6^{\text {cde }}$ & $34,5^{\mathrm{abc}}$ & ** & 0,7 & , \\
\hline N-FDA ${ }^{1}$ & $18.0^{\mathrm{abc}}$ & $22.4^{\text {cde }}$ & $21.5^{\text {bcde }}$ & $16.2^{\mathrm{ab}}$ & $22.7^{\text {cde }}$ & $24,2^{\text {de }}$ & $24.3^{\mathrm{e}}$ & $13.8^{\mathrm{a}}$ & $26.0^{e}$ & $18.6^{\mathrm{abcd}}$ & $21,2^{\text {bcde }}$ & $17.9^{\mathrm{abc}}$ & 0.2 & & ** \\
\hline $\mathrm{B}^{1}{ }^{1}$ & $21,1^{\mathrm{f}}$ & $19,2^{\text {cdef }}$ & $14,2^{\mathrm{abcd}}$ & $13,5^{\text {abcd }}$ & $12,9^{\mathrm{ab}}$ & $15,5^{\text {abcde }}$ & $19,4^{\text {def }}$ & $20,5^{\mathrm{ef}}$ & $10,4^{\mathrm{a}}$ & $13,3^{\mathrm{abc}}$ & $18,5^{\text {bcdef }}$ & $16,7^{\text {bcdef }}$ & * & * & 0,3 \\
\hline $\mathrm{MM}, \% \mathrm{MS}$ & $13,1^{d}$ & $12,7^{\mathrm{cd}}$ & $12,7^{c d}$ & $11,7^{\mathrm{abc}}$ & $11,4^{\mathrm{ab}}$ & $11,4^{\mathrm{ab}}$ & $10,9^{a b}$ & $10,8^{\mathrm{a}}$ & $13,4^{d}$ & $13,1^{d}$ & $1,9^{b c}$ & $12,4^{\mathrm{cd}}$ & ** & 0,1 & 0,8 \\
\hline EE, \%MS & $1,7^{d}$ & $1,6^{c}$ & $1,7^{\mathrm{cd}}$ & $1,5^{b}$ & $1,9^{\mathrm{e}}$ & $2,2^{f}$ & $1,7^{\text {cd }}$ & $1,7^{d}$ & $1,2^{\mathrm{a}}$ & $1,1^{\mathrm{a}}$ & $1,5^{b}$ & $1,3^{\mathrm{a}}$ & ** & $* *$ & 0,1 \\
\hline NDT \%MS & $52.1^{\mathrm{bcc}}$ & $524^{\mathrm{bcd}}$ & $527^{\text {cde }}$ & $52.6^{\text {cde }}$ & $55.5^{\mathrm{ef}}$ & $56.1^{\dagger}$ & $54.4^{\text {def }}$ & $57.0^{f}$ & $49.6^{a}$ & $50.2^{\mathrm{ab}}$ & $516^{\mathrm{abc}}$ & $518^{\mathrm{abc}}$ & ** & 0.9 & 0.7 \\
\hline
\end{tabular}

porcentagem sobre o nitrogênio total. (MO - forragem ou silagem com a umidade original; MOPC - forragem ou silagem com adição de polpa cítrica peletizada; PE - forragem ou silagem pré-emurchecida; PMa - partícula maior; PMe - partícula menor; C - com inoculante bacteriano; $\mathrm{S}$-sem inoculante bacteriano; TMS - efeito da alteração no teor de matéria seca; PART - efeito do tamanho de partícula; INOC - efeito do inoculante bacteriano; Hem - hemicelulose; Lig - lignina; ** $\mathrm{P}<0,01 ; * \mathrm{P}<0,05)$. 
Tabela 2. Médias do valor nutritivo da forragem e da silagem de capim Tanzânia colhidas durante o verão.

\begin{tabular}{|c|c|c|c|c|c|c|c|c|c|c|c|c|c|c|c|}
\hline \multirow[b]{3}{*}{ Parametros } & \multicolumn{4}{|c|}{$\mathrm{MO}$} & \multicolumn{4}{|c|}{ MOPC } & \multicolumn{4}{|c|}{$\mathrm{PE}$} & \multirow{2}{*}{\multicolumn{3}{|c|}{ EFEITOS }} \\
\hline & \multicolumn{2}{|c|}{ PMe } & \multicolumn{2}{|c|}{ PMa } & \multicolumn{2}{|c|}{ PMe } & \multicolumn{2}{|c|}{ PMa } & \multicolumn{2}{|c|}{ PMe } & \multicolumn{2}{|c|}{ PMa } & & & \\
\hline & C & S & C & S & C & S & C & S & C & S & C & $\mathrm{S}$ & TMS & PART & INOC \\
\hline \multicolumn{16}{|l|}{ Forragem } \\
\hline MS, $\%$ & 15,7 & 15,6 & 17,5 & 16,6 & 28,4 & 27,7 & 25,7 & 25,9 & 22,1 & 21,1 & 21,5 & 21,5 & - & - & - \\
\hline $\mathrm{PB}, \% \mathrm{MS}$ & 6,4 & 6,5 & 7,1 & 8,4 & 5,9 & 6,1 & 7,1 & 6,6 & 8,7 & 8,4 & 9,3 & 9,2 & - & - & - \\
\hline CNF, \%MS & 18,3 & 19,7 & 13,5 & 21,1 & 37,8 & 37,8 & 29,2 & 32,1 & 12,6 & 14,8 & 8,7 & 7,6 & - & - & - \\
\hline FDN, \%MS & 65,1 & 61,8 & 69,2 & 61,1 & 46,5 & 49,0 & 53,3 & 52,4 & 68,9 & 67,2 & 71,3 & 72,9 & - & - & - \\
\hline FDA, \%MS & 43,3 & 43,3 & 41,2 & 43,1 & 31,8 & 30,5 & 37,7 & 33,1 & 44,8 & 42,1 & 42,5 & 39,8 & - & - & - \\
\hline Hem, \%MS & 21,8 & 18,5 & 28,0 & 18,1 & 14,7 & 18,6 & 15,7 & 19,4 & 24,2 & 25,1 & 28,7 & 33,1 & - & - & - \\
\hline Lig, \%MS & 4,4 & 4,7 & 3,9 & 2,8 & 4,4 & 3,3 & 4,8 & 4,6 & 5,1 & 4,8 & 4,9 & 4,5 & - & - & - \\
\hline$N-F D N^{1}$ & 39,3 & 38,9 & 40,3 & 40,7 & 43,5 & 45,3 & 42,1 & 37,6 & 41,2 & 33,9 & 34,5 & 38,3 & - & - & - \\
\hline$N-F^{1}{ }^{1}$ & 15,8 & 16,9 & 20,1 & 19,6 & 20,2 & 26,1 & 27,6 & 23,8 & 13,0 & 11,6 & 22,0 & 17,9 & - & - & - \\
\hline $\mathrm{B}^{1}$ & 23,5 & 22,0 & 20,2 & 21,2 & 23,3 & 19,2 & 14,5 & 13,9 & 28,2 & 22,4 & 12,5 & 20,4 & - & - & - \\
\hline MM, \%MS & 11,5 & 13,5 & 12,1 & 11,8 & 11,0 & 8,4 & 12,0 & 10,0 & 12,4 & 11,6 & 12,7 & 13,1 & - & - & - \\
\hline EE, \%MS & 1,2 & 1,1 & 1,1 & 1,1 & 1,5 & 1,5 & 1,5 & 1,4 & 1,1 & 0,9 & 1,4 & 0,8 & - & - & - \\
\hline NDT, \%MS & 54,8 & 53,0 & 53,8 & 58,8 & 60,1 & 64,3 & 57,0 & 59,2 & 52,4 & 53,3 & 50,9 & 50,6 & - & - & . \\
\hline \multicolumn{16}{|l|}{ Silagem } \\
\hline MS, $\%$ & $14,3^{a}$ & $13,7^{\mathrm{a}}$ & $17,4^{b}$ & $17,1^{b}$ & $27,6^{d}$ & $26,5^{d}$ & $27,3^{d}$ & $27,5^{d}$ & $21,4^{\mathrm{C}}$ & $20,9^{c}$ & $21,4^{\mathrm{C}}$ & $21,5^{c}$ & ** & ** & 0,4 \\
\hline $\mathrm{PB}, \% \mathrm{MS}$ & $6,4^{b c}$ & $6,1^{\mathrm{abc}}$ & $6,0^{\mathrm{ab}}$ & $6,5^{b c}$ & $6,7^{c}$ & $6,0^{a b}$ & $6,0^{\mathrm{ab}}$ & $6,3^{\mathrm{abc}}$ & $5,8^{a}$ & $6,5^{b c}$ & $5,9^{a b}$ & $6,7^{\mathrm{C}}$ & * & 0,5 & * \\
\hline CNF, \%MS & $4,5^{\mathrm{a}}$ & $10,1^{b}$ & $10,7^{b}$ & $11,6^{\mathrm{b}}$ & $29,5^{\mathrm{cd}}$ & $26,9^{c}$ & $32,4^{d}$ & $28,6^{\mathrm{cd}}$ & $10,9^{b}$ & $8,9^{a b}$ & $7,7^{\mathrm{ab}}$ & $8,1^{a b}$ & ** & 0,3 & 0,1 \\
\hline FDN, \%MS & $66,2^{\mathrm{C}}$ & $68,2^{c}$ & $69,5^{\mathrm{c}}$ & $66,8^{\mathrm{c}}$ & $51,6^{\mathrm{ab}}$ & $56,4^{b}$ & $49,9^{a}$ & $52,7^{\mathrm{ab}}$ & $68,1^{\mathrm{C}}$ & $69,1^{\mathrm{C}}$ & $70,2^{C}$ & $70,9^{C}$ & ** & 0,6 & 0,8 \\
\hline FDA, \%MS & $44,3^{b c}$ & $48,4^{c}$ & $47,3^{\mathrm{bc}}$ & $43,3^{\mathrm{b}}$ & $30,9^{a}$ & $34,6^{\mathrm{a}}$ & $33,08^{a}$ & $34,3^{\mathrm{a}}$ & $44,7^{\mathrm{bc}}$ & $44,5^{\mathrm{bc}}$ & $45,1^{b c}$ & $46,2^{\mathrm{bc}}$ & ** & 0,78 & 0,6 \\
\hline Hem, \%MS & $21,6^{\text {acde }}$ & $19,8^{\text {acd }}$ & $22,1^{\text {cde }}$ & $23,5^{\mathrm{de}}$ & $20,7^{\text {acde }}$ & $21,6^{\text {acde }}$ & $16,8^{\mathrm{a}}$ & $18,4^{\mathrm{ac}}$ & $23,4^{\mathrm{de}}$ & $24,5^{\mathrm{e}}$ & $25,1^{\mathrm{e}}$ & $24,8^{\mathrm{e}}$ & ** & 0,5 & 0,8 \\
\hline Lig., \%MS & $5,9^{\mathrm{de}}$ & $5,6^{d}$ & $5,3^{\mathrm{cd}}$ & $5,4^{\text {cd }}$ & $3,7^{\mathrm{a}}$ & $3,7^{\mathrm{a}}$ & $3,9^{\mathrm{a}}$ & $3,9^{\mathrm{a}}$ & $4,6^{\mathrm{b}}$ & $4,9^{b c}$ & $6,5^{\mathrm{e}}$ & $6,3^{\mathrm{e}}$ & ** & $*$ & 0,5 \\
\hline N-FDN ${ }^{1}$ & $32,5^{\mathrm{bcd}}$ & $26,4^{a}$ & $26,3^{\mathrm{a}}$ & $27,2^{a}$ & $34,4^{\text {cde }}$ & $28,3^{\mathrm{ab}}$ & $36,4^{\text {de }}$ & $30,2^{\mathrm{abc}}$ & $36,5^{\mathrm{de}}$ & $35,3^{\text {cde }}$ & $43,9^{\dagger}$ & $39,2^{\text {ef }}$ & ** & 0,7 & 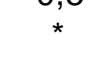 \\
\hline N-FDA ${ }^{1}$ & $21,3^{\mathrm{ab}}$ & $23,7^{\mathrm{bc}}$ & $20,0^{\mathrm{ab}}$ & $17,6^{\mathrm{a}}$ & $26,9^{c}$ & $23,2^{b c}$ & $24,4^{\mathrm{bc}}$ & $18,7^{\mathrm{a}}$ & $20,9^{\mathrm{ab}}$ & $21,4^{\mathrm{ab}}$ & $22,4^{\mathrm{abc}}$ & $22,1^{\mathrm{abc}}$ & 0,2 & * & ** \\
\hline $\mathrm{B}^{1}$ & $11,3^{\text {bcdef }}$ & $2,6^{\mathrm{a}}$ & $6,3^{\mathrm{abc}}$ & 9,6 bcde & $7,5^{\text {abcd }}$ & $5,1^{\mathrm{ab}}$ & $12,0^{\text {cdef }}$ & $11,5^{\text {bcdef }}$ & $15,6^{\text {efg }}$ & $13,9^{\text {def }}$ & $21,1^{g}$ & $17,0^{f g}$ & $*$ & * & 0,3 \\
\hline MM, \%MS & $1,6^{b}$ & $1,8^{\text {def }}$ & $1,8^{\text {cde }}$ & $1,8^{\mathrm{de}}$ & $1,8^{b c d}$ & $19,5^{f g}$ & $1,7^{b c}$ & $1,8^{\mathrm{de}}$ & $1,9^{\text {efg }}$ & $2,0^{9}$ & $1,4^{\mathrm{a}}$ & $1,4^{\mathrm{a}}$ & ** & 0,1 & 0,8 \\
\hline EE, \%MS & $13,4^{\mathrm{cd}}$ & $13,7^{c d}$ & $12,6^{\mathrm{dc}}$ & $13,24^{c d}$ & $9,8^{\mathrm{a}}$ & $11,1^{\mathrm{ab}}$ & $10,0^{\mathrm{a}}$ & $10,6^{\mathrm{a}}$ & $13,3^{\mathrm{cd}}$ & $13,6^{\mathrm{cd}}$ & $14,8^{d}$ & $13,1^{\mathrm{cd}}$ & ** & $\star *$ & 0,1 \\
\hline NDT, \%MS & $48,0^{\mathrm{bc}}$ & $47,7^{\mathrm{bc}}$ & $49,9^{c}$ & $49,2^{c}$ & $58,8^{\text {de }}$ & $57,8^{d}$ & $59,2^{\mathrm{e}}$ & $58,3^{\text {de }}$ & $50,2^{c}$ & $49,1^{\mathrm{c}}$ & $44,1^{\mathrm{a}}$ & $45,9^{\mathrm{ab}}$ & ** & 0,9 & 0,7 \\
\hline
\end{tabular}

porcentagem sobre o nitrogênio total. (MO - forragem ou silagem com a umidade original; MOPC - forragem ou silagem com adição de polpa cítrica peletizada; PE - forragem ou silagem pré-emurchecida; PMa - partícula maior; PMe - partícula menor; C - com inoculante bacteriano; S -sem inoculante bacteriano; TMS - efeito da alteração no teor de matéria seca; PART - efeito do tamanho de partícula; INOC - efeito do inoculante bacteriano; Hem - hemicelulose; Lig. - lignina; $\left.{ }^{* *}-\mathrm{P}<0,01 ;{ }^{*}-\mathrm{P}<0,05\right)$. 
Tabela 3. Médias das perdas e dos parâmetros fermentativos da silagem de capim Tanzânia colhidas durante o inverno.

\begin{tabular}{|c|c|c|c|c|c|c|c|c|c|c|c|c|c|c|c|}
\hline \multirow[b]{3}{*}{ Parâmetros } & \multicolumn{4}{|c|}{$\mathrm{MO}$} & \multicolumn{4}{|c|}{ MOPC } & \multicolumn{4}{|c|}{$\mathrm{PE}$} & \multirow{2}{*}{\multicolumn{3}{|c|}{ EFEITOS }} \\
\hline & \multicolumn{2}{|c|}{$\mathrm{PMe}$} & \multicolumn{2}{|c|}{$\mathrm{PMa}$} & \multicolumn{2}{|c|}{$\mathrm{PMe}$} & \multicolumn{2}{|c|}{$\mathrm{PMa}$} & \multicolumn{2}{|c|}{$\mathrm{PMe}$} & \multicolumn{2}{|c|}{ PMa } & & & \\
\hline & $\mathrm{C}$ & $S$ & $\mathrm{C}$ & $\mathrm{S}$ & $\mathrm{C}$ & $\mathrm{S}$ & $\mathrm{C}$ & $S$ & $\mathrm{C}$ & $\mathrm{S}$ & $\mathrm{C}$ & $S$ & TMS & PART & $\overline{I N O C}$ \\
\hline \multicolumn{16}{|l|}{ Forragem } \\
\hline MS,\% & 29,5 & 29,3 & 30,0 & 30,1 & 32,5 & 32,5 & 33,2 & 33,3 & 36,8 & 37,2 & 38,2 & 38,5 & - & - & - \\
\hline AW & 0,96 & 0,96 & 0,96 & 0,96 & 0,94 & 0,94 & 0,94 & 0,94 & 0,93 & 0,93 & 0,93 & 0,93 & - & - & - \\
\hline $\mathrm{pH}$ & 6,40 & 6,52 & 6,00 & 6,09 & 6,10 & 6,03 & 5,80 & 5,89 & 6,27 & 6,26 & 6,20 & 6,18 & - & - & - \\
\hline $\mathrm{PT}^{1}$ & 22,2 & 21,2 & 25,4 & 26,7 & 26,4 & 27,5 & 27,5 & 27,0 & 19,1 & 18,0 & 21,3 & 21,8 & - & - & - \\
\hline NA. \%Ntotal & 3,0 & 3,3 & 2,8 & 3,6 & 3,3 & 2,3 & 2,0 & 2,7 & 2,1 & 2,2 & 2,3 & 2,8 & - & - & - \\
\hline CE (ì S.cm ${ }^{-1}$ ) & 1173 & 1185 & 940 & 938 & 1235 & 1125 & 989 & 1083 & 1227 & 1235 & 895 & 854 & - & - & - \\
\hline \multicolumn{15}{|l|}{ Silagem } & - \\
\hline Densidade $^{3}$ & $160^{c}$ & $150^{\mathrm{bc}}$ & $134^{\mathrm{a}}$ & $140^{\mathrm{ab}}$ & $183^{d}$ & $177^{d}$ & $161^{c}$ & $160^{c}$ & $143^{\mathrm{ab}}$ & $145^{\mathrm{ab}}$ & $134^{\mathrm{a}}$ & $144^{\mathrm{ab}}$ & * & ** & 0,8 \\
\hline Densidade $^{4}$ & $543^{g}$ & $514^{\dagger}$ & $445^{d}$ & $466^{e}$ & $533^{f g}$ & $520^{f}$ & $457^{\mathrm{de}}$ & $453^{\mathrm{de}}$ & $388^{\mathrm{C}}$ & $395^{\mathrm{C}}$ & $350^{\mathrm{a}}$ & $375^{\mathrm{b}}$ & * & * & 0,1 \\
\hline $\mathrm{pH}$ & $4,11^{\mathrm{abc}}$ & $3,94^{\mathrm{a}}$ & $4,43^{\mathrm{C}}$ & $4,23^{\mathrm{C}}$ & $3,84^{a}$ & $3,97^{\mathrm{a}}$ & $3,99^{\mathrm{ab}}$ & $4,23^{\mathrm{C}}$ & $4,22^{\mathrm{C}}$ & $4,18^{\mathrm{C}}$ & $4,21^{\mathrm{c}}$ & $4,17^{\mathrm{bc}}$ & ** & ** & 0,4 \\
\hline $\mathrm{PT}^{1}$ & $52,1^{\mathrm{ef}}$ & $48,6^{\mathrm{bcde}}$ & $59,4^{\dagger}$ & $50,6^{\text {def }}$ & $41,0^{\mathrm{abcd}}$ & $50,2^{\text {cdef }}$ & $42,1^{\mathrm{abcd}}$ & $40,1^{\mathrm{ab}}$ & $52,4^{\mathrm{ef}}$ & $40,5^{\mathrm{abc}}$ & $36,8^{\mathrm{a}}$ & $33,7^{a}$ & $\star \star *$ & * & 0,4 \\
\hline NA, \% Ntotal & $7,3^{b}$ & $7,3^{b}$ & $5,2^{\text {acd }}$ & $5,5^{\mathrm{cd}}$ & $5,2^{\text {acd }}$ & $5,6^{d}$ & $5,4^{\text {cd }}$ & $5,0^{\text {acd }}$ & $4,5^{\mathrm{a}}$ & $5,1^{\text {acd }}$ & $4,9^{\mathrm{ac}}$ & $4,9^{\mathrm{ac}}$ & $\star \star *$ & ** & 0,5 \\
\hline CE (ì S.cm ${ }^{-1}$ ) & $1512^{\text {efg }}$ & $1488^{\text {cdef }}$ & $1372^{\mathrm{ab}}$ & $1387^{\mathrm{ab}}$ & $1453^{\text {bcde }}$ & $1497^{\mathrm{def}}$ & $1355^{\mathrm{a}}$ & $1377^{\mathrm{ab}}$ & $1586^{g}$ & $1548^{f g}$ & $1426^{\mathrm{abcd}}$ & $1415^{\mathrm{abc}}$ & ** & ** & 0,1 \\
\hline Efluente $^{5}$ & $10,9^{C}$ & $11,1^{\mathrm{C}}$ & $5,1^{\mathrm{ab}}$ & $9,1^{\mathrm{bc}}$ & $2,0^{\mathrm{a}}$ & $3,9^{\mathrm{a}}$ & $1,8^{\mathrm{a}}$ & $3,8^{\mathrm{a}}$ & $5,7^{\mathrm{ab}}$ & $3,6^{\mathrm{a}}$ & $2,2^{\mathrm{a}}$ & $2,1^{\mathrm{a}}$ & ** & 0,9 & 0,4 \\
\hline MS recup, ${ }^{6}$ & $96,9^{\mathrm{a}}$ & $96,2^{\mathrm{a}}$ & $96,6^{\mathrm{a}}$ & $98,1^{\mathrm{a}}$ & $98,4^{a}$ & $97,5^{\mathrm{a}}$ & $98,5^{\mathrm{a}}$ & $98,1^{a}$ & $98,4^{\mathrm{a}}$ & $97,3^{\mathrm{a}}$ & $96,9^{\mathrm{a}}$ & $96,6^{a}$ & ** & $* *$ & 0,9 \\
\hline Gás $\left(\% . M^{-1}\right)$ & $3,5^{\mathrm{bcd}}$ & $3,1^{\mathrm{abcd}}$ & $2,9^{\mathrm{abcd}}$ & $4,0^{c d}$ & $1,0^{\mathrm{a}}$ & $4,2^{\mathrm{cd}}$ & $3,11^{\mathrm{abcd}}$ & $3,1^{\mathrm{abcd}}$ & $1,6^{\mathrm{ab}}$ & $3,1^{\mathrm{abcd}}$ & $2,3^{\text {abe }}$ & $4,4^{d}$ & ** & 0,9 & 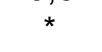 \\
\hline Estabilidade $^{7}$ & $150,0^{a}$ & $151,5^{\mathrm{a}}$ & $150,6^{a}$ & $156,6^{a}$ & $151,9^{\mathrm{a}}$ & $151,3^{\mathrm{a}}$ & $151,5^{\mathrm{a}}$ & $150,2^{a}$ & $150,6^{a}$ & $152,3^{\mathrm{a}}$ & $151,4^{\mathrm{a}}$ & $154,4^{\mathrm{a}}$ & ** & $* *$ & 0,4 \\
\hline
\end{tabular}

mequiv.100gMS ${ }^{-1} ;{ }^{2}$ porcentagem de MS retida na peneira de $1,905 \mathrm{~cm} ;{ }^{3} \mathrm{~kg}$ silagem. $\mathrm{m}^{-3} ;{ }^{4} \mathrm{~kg}$ de MS silagem. ${ }^{-3} ;{ }^{5} \mathrm{~kg} . \mathrm{t}$ forragem ${ }^{-1}$; ${ }^{6}$ porcentagem de matéria seca recuperada no silo experimental; ${ }^{7}$ temperatura acumulada da silagem nos 5 dias pós abertura do silo;

(MO - forragem ou silagem com a umidade original; MOPC - forragem ou silagem com adição de polpa cítrica peletizada; PE - forragem ou silagem pré-emurchecida; PMa - partícula maior; PMe - partícula menor; $\mathrm{C}$ - com inoculante bacteriano; $\mathrm{S}$-sem inoculante bacteriano; TMS - efeito da alteração no teor de matéria seca; PART - efeito do tamanho de partícula; INOC - efeito do inoculante bacteriano; PT - poder tampão; $\mathrm{N}-\mathrm{NH}_{3} / \mathrm{Ntotal}$ - nitrogênio amoniacal em porcentagem do nitrogênio total; AW - atividade de água; CE condutividade elétrica; ${ }^{*}$ - $\left.\mathrm{P}<0,01 ;{ }^{*}-\mathrm{P}<0,05\right)$. 
Tabela 4. Médias das perdas e dos parâmetros fermentativos da silagem de capim Tanzânia colhidas durante o verão.

\begin{tabular}{|c|c|c|c|c|c|c|c|c|c|c|c|c|c|c|c|}
\hline \multirow[b]{3}{*}{ Parâmetros } & \multicolumn{4}{|c|}{$\mathrm{MO}$} & \multicolumn{4}{|c|}{ MOPC } & \multicolumn{4}{|c|}{$\mathrm{PE}$} & \multirow{2}{*}{\multicolumn{3}{|c|}{ EFEITOS }} \\
\hline & \multicolumn{2}{|c|}{ PMe } & \multicolumn{2}{|c|}{ PMa } & \multicolumn{2}{|c|}{ PMe } & \multicolumn{2}{|c|}{ PMa } & \multicolumn{2}{|c|}{ Pme } & \multicolumn{2}{|c|}{$\mathrm{PMa}$} & & & \\
\hline & $\mathrm{C}$ & $S$ & $\mathrm{C}$ & $S$ & $\mathrm{C}$ & $S$ & $\mathrm{C}$ & $S$ & $\mathrm{C}$ & S & $\mathrm{C}$ & $S$ & TMS & PART & INOC \\
\hline Forragem & & & & & & & & & & & & & & & \\
\hline MS,\% & 15,7 & 15,6 & 17,5 & 16,6 & 28,4 & 27,7 & 25,7 & 25,9 & 22,1 & 21,1 & 21,5 & 21,5 & - & - & - \\
\hline AW & 0,98 & 0,97 & 0,98 & 0,97 & 0,99 & 0,97 & 0,99 & 0,97 & 0,98 & 0,97 & 0,98 & 0,97 & - & - & - \\
\hline $\mathrm{pH}$ & 5,77 & 5,72 & 6,28 & 6,03 & 5,51 & 5,69 & 5,50 & 5,65 & 5,93 & 5,56 & 6,70 & 6,31 & - & - & - \\
\hline $\mathrm{PT}^{1}$ & 15,5 & 14,7 & 13,4 & 16,8 & 22,7 & 18,5 & 21,5 & 29,9 & 8,4 & 11,1 & 14,5 & 13,0 & - & - & - \\
\hline NA. \% Ntotal & 3,5 & 3,1 & 3,1 & 3,0 & 3,9 & 3,3 & 3,1 & 3,2 & 3,1 & 3,3 & 2,8 & 2,9 & _ & - & - \\
\hline CE (ì S.cm ${ }^{-1}$ ) & 1677 & 1511 & 1446 & 1431 & 1402 & 1623 & 1470 & 1474 & 1935 & 1631 & 1528 & 1595 & - & - & - \\
\hline Partícula ${ }^{2}$ & 77,9 & 75,1 & 82,6 & 86,6 & 34,4 & 52,5 & 53,6 & 45,6 & 63,4 & 66,7 & 71,5 & 78,0 & - & - & - \\
\hline Silag & & & & & & & & & & & & & & & \\
\hline Densidade $^{3}$ & $96^{a}$ & $97^{\mathrm{a}}$ & $104^{a}$ & $103^{a}$ & $186^{\mathrm{b}}$ & $183^{b}$ & $175^{\mathrm{b}}$ & $176^{\mathrm{b}}$ & $100^{\mathrm{a}}$ & $103^{a}$ & $104^{a}$ & $109^{a}$ & * & ** & 0,8 \\
\hline Densidade $^{4}$ & $669^{\mathrm{cd}}$ & $704^{d}$ & $599^{b}$ & $599^{b}$ & $673^{\mathrm{cd}}$ & $692^{d}$ & $638^{\mathrm{bc}}$ & $641^{\mathrm{bc}}$ & $465^{a}$ & $493^{a}$ & $486^{a}$ & $504^{a}$ & * & * & 0,1 \\
\hline $\mathrm{pH}_{1}$ & $5,38^{9}$ & $5,39^{9}$ & $5,07^{\mathrm{e}}$ & $5,18^{f}$ & $3,95^{\mathrm{ab}}$ & $3,94^{\mathrm{ab}}$ & $3,87^{\mathrm{a}}$ & $3,99^{b}$ & $4,83^{c}$ & $5,01^{d}$ & $5,40^{9}$ & $5,36^{9}$ & ** & ** & 0,4 \\
\hline $\mathrm{PT}^{1}$ & $154,1^{\mathrm{e}}$ & $160,7^{0}$ & $113,8^{\mathrm{cd}}$ & $119,9^{d}$ & $72,1^{\mathrm{a}}$ & $75,5^{\mathrm{a}}$ & $71,2^{\mathrm{a}}$ & $78,9^{\mathrm{ab}}$ & $97,7^{b c}$ & $121,3^{d}$ & $128,3^{d}$ & $121,8^{d}$ & $* *$ & * & 0,4 \\
\hline NA, \% Ntotal & $22,6^{d}$ & $22,6^{d}$ & $19,4^{\mathrm{C}}$ & $18,5^{\mathrm{C}}$ & $5,7^{\mathrm{a}}$ & $5,7^{\mathrm{a}}$ & $5,5^{\mathrm{a}}$ & $5,8^{\mathrm{a}}$ & $11,6^{b}$ & $10,8^{b}$ & $11,2^{b}$ & $12,1^{b}$ & $* \star$ & ** & 0,5 \\
\hline CE (ì S.cm $\left.{ }^{-1}\right)$ & $2127^{\mathrm{de}}$ & $2155^{\mathrm{e}}$ & $1973^{\mathrm{bc}}$ & $2009^{c d}$ & $1825^{\mathrm{a}}$ & $1873^{\mathrm{ab}}$ & $1854^{\mathrm{ab}}$ & $1849^{\mathrm{ab}}$ & $2393^{\dagger}$ & $2414^{\dagger}$ & $2103^{\mathrm{de}}$ & $2215^{\mathrm{e}}$ & $* *$ & ** & 0,1 \\
\hline Efluente $^{5}$ & $47,4^{c}$ & $44,0^{\mathrm{bc}}$ & $66,8^{d}$ & $49,0^{c}$ & $32,5^{\mathrm{ab}}$ & $42,9^{b c}$ & $20,7^{\mathrm{a}}$ & $25,2^{a b}$ & $20,2^{a}$ & $34,4^{\mathrm{abc}}$ & $36,2^{\mathrm{bc}}$ & $38,4^{b c}$ & $* *$ & 0,9 & 0,4 \\
\hline MS recup, ${ }^{6}$ & $85,9^{\mathrm{ab}}$ & $83,4^{a}$ & $91,4^{\mathrm{cb}}$ & $91,5^{b c}$ & $91,9^{b c}$ & $91,0^{b c}$ & $98,8^{d}$ & $97,6^{\mathrm{cd}}$ & $93,6^{c d}$ & $93,0^{\text {cd }}$ & $94,5^{\mathrm{cd}}$ & $95,1^{\text {cd }}$ & $* *$ & $* *$ & 0,9 \\
\hline Gás (\%.MS $\left.{ }^{-1}\right)$ & $8,6^{d}$ & $9,0^{d}$ & $5,8^{c}$ & $5,6^{c}$ & $2,9^{\mathrm{a}}$ & $2,6^{a}$ & $3,2^{\mathrm{ab}}$ & $2,8^{\mathrm{a}}$ & $5,2^{\mathrm{bc}}$ & $5,3^{\mathrm{c}}$ & $6,3^{\mathrm{c}}$ & $6,6^{\mathrm{C}}$ & $* *$ & 0,9 & $x$ \\
\hline Estabilidade $^{7}$ & $78,1^{a}$ & $79,4^{a}$ & $100,1^{b}$ & $98,9^{b}$ & $98,0^{b}$ & $99,4^{b}$ & $97,3^{b}$ & $96,1^{\mathrm{b}}$ & $99,3^{b}$ & $100,4^{b}$ & $98,0^{b}$ & $96,1^{b}$ & $* *$ & ** & 0,4 \\
\hline
\end{tabular}

${ }^{1}$ mequiv. $100 \mathrm{gMS}^{-1} ;{ }^{2}$ porcentagem de MS retida na peneira de $1,905 \mathrm{~cm} ;{ }^{3} \mathrm{~kg}$ silagem. $\mathrm{m}^{-3} ;{ }^{4} \mathrm{~kg}$ de MS silagem. ${ }^{-3} ;{ }^{5} \mathrm{~kg} . \mathrm{t}$ forragem ${ }^{-1}$; ${ }^{6}$ porcentagem de matéria seca recuperada no silo experimental; ${ }^{7}$ temperatura acumulada da silagem nos 5 dias pós abertura do silo; (MO - forragem ou silagem com a umidade original; MOPC - forragem ou silagem com adição de polpa cítrica peletizada; PE - forragem ou silagem pré-emurchecida; PMa - partícula maior; PMe - partícula menor; C - com inoculante bacteriano; S -sem inoculante bacteriano; TMS - efeito da alteração no teor de matéria seca; PART - efeito do tamanho de partícula; INOC - efeito do inoculante bacteriano; PT - poder tampão; $\mathrm{N}-\mathrm{NH}_{3} / \mathrm{Ntotal}$ - nitrogênio amoniacal em porcentagem do nitrogênio total; $\mathrm{AW}$ - atividade de água; $\mathrm{CE}$ condutividade elétrica; $\left.{ }^{* *}-\mathrm{P}<0,01{ }^{*}{ }^{*} \mathrm{P}<0,05\right)$. 
Seguindo a fórmula proposta por Greenhill (1964), a AW da forragem é determinada pela seguinte equação:

$\mathrm{AW}=1-\mathrm{c} / \mathrm{m}$,

Onde AW representa a atividade de água da planta (umidade relativa de pressão de vapor), $m$ se refere a umidade contida (expressa em gramas de água por gramas de matéria seca), c uma constante (determinada pela contribuição das moléculas e íons da planta). O autor calculou o termo $c$ (constante) para diversas plantas, verificando a influência de diversos fatores, como por exemplo, a idade da planta, constatando-se valores para azevém na ordem de 0,04 à 0,02, e de trevo e alfafa, de 0,05 à 0,03. Aplicado -se a fórmula proposta acima, para os dados referentes ao capim Panicum maximum cv. Tanzânia, foram obtidos valores superiores para a constante $c$ em relação aos citados por Greenhill (1964), variando entre 0,08 à 0,13 (Anexo D). Isso sugere que a somatória da carga iônica e o peso das moléculas das gramíneas tropicais, seja maior em relação as forrageiras temperadas.

A maior quantidade de carga iônica e peso das moléculas, permitiria uma umidade mais elevada na planta, sem necessária alteração na atividade de água (AW). Isso sugere que na ensilagem de gramíneas tropicais, o teor de matéria seca (MS) recomendado pela literatura internacional talvez seja super estimado, pois baseia-se em dados de forragens de clima temperado. Assim, gramíneas tropicais poderiam obter sucesso na redução de fermentação por Clostrídios, em teores de matéria seca mais reduzidos, quando comparados com forrageiras temperadas. 


\subsubsection{Tamanho de partículas e densidade}

A caracterização do tamanho de partículas foi apresentada nas Tabelas 3 e 4, sendo mensurada a porcentagem de matéria seca retida na peneira de $1,905 \mathrm{~cm}$ de diâmetro. O tamanho de partícula do material a ser ensilado é uma importante mensuração que tem efeito direto na compactação durante a ensilagem, apresentado influência no processo fementativo.

$\mathrm{Na}$ Figura 5, está representada a relação obtida no presente experimento entre a densidade da silagem e o tamanho de partícula. Observa-se uma tendência linear de aumento no valor da densidade $\left(\mathrm{kg}\right.$ de silagem. $\left.\mathrm{m}^{-3}\right)$, a medida que a porcentagem de matéria seca retida na peneira de $1,905 \mathrm{~cm}$ de diâmetro é diminuída, ou seja, quanto menor o tamanho da partícula houve o esperado efeito de aumento na densidade da silagem.

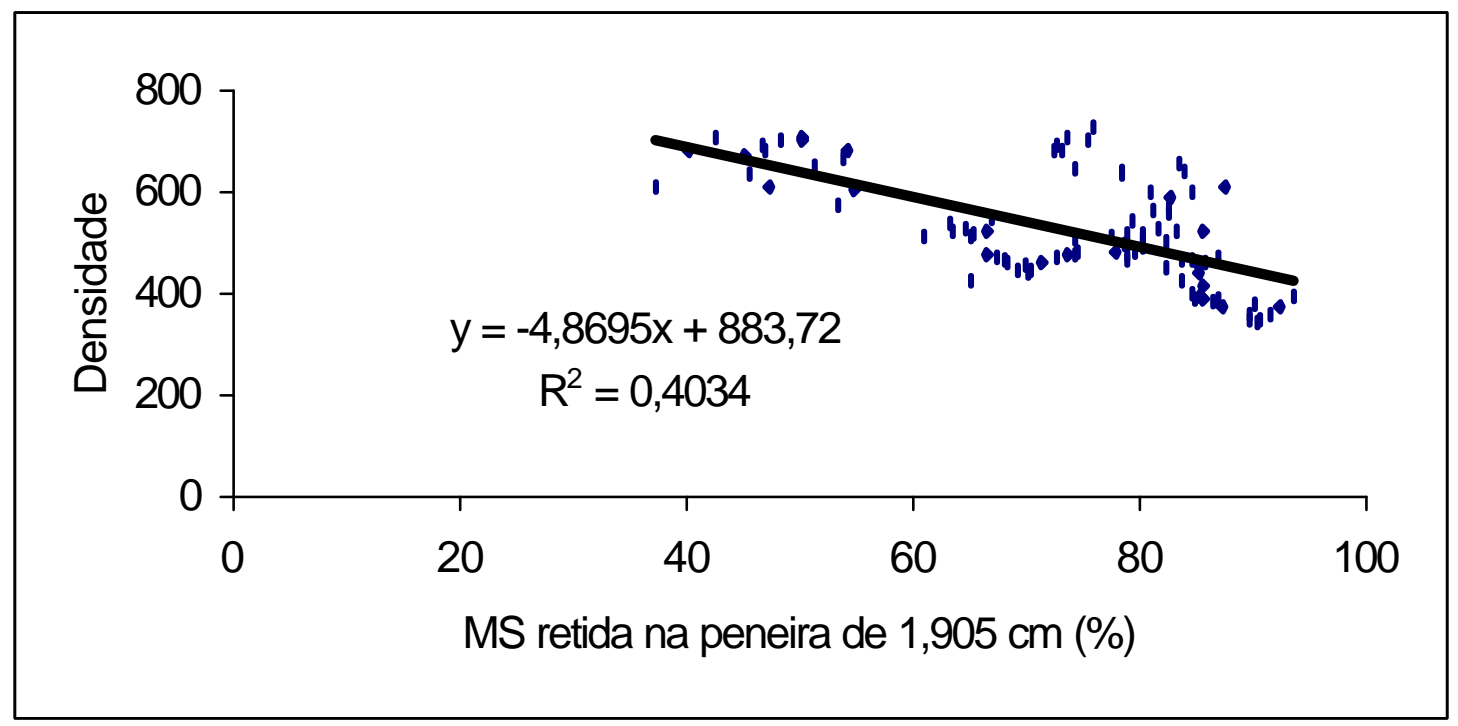

Figura 5 - Efeito do tamanho de partícula na densidade $\left(\mathrm{kg}\right.$ de silagem. $\left.\mathrm{m}^{3}\right)$, em silagem de capim Tanzânia. 
Contudo, a equação apresentada na Figura 5 , mostrourse com $\circ R^{2}$ relativamente baixo, sugerindo que a mensuração do tamanho de partícula através da porcentagem retida na peneira de 1,905 cm de diâmetro, tenha pouca sensibilidade para caracterizar diferenças na dimensão da partícula picada pelos tamanhos sugeridos no presente experimento.

A metodologia proposta por Lammers et al. (1996), objetiva uma estimativa do tamanho médio das partículas, através de uma função matemática (Weibull), em que os valores de porcentagem de material retido em cada peneira, resultam em valor médio do tamanho de partícula. Entretanto, tal função tornourse inviável, pelo fato dos pontos originados no gráfico da função, estarem distantes do ponto interpretado como sendo o valor médio do tamanho das partículas, e assim a equação tornoutse pouco sensível para estimar esse valor.

Dessa forma, torna-se necessário a admissão de um ponto adicional no gráfico da função, mais próximo do valor do tamanho médio das partículas, sendo proposta a inclusão de uma peneira com diâmetro aproximado a $4 \mathrm{~cm}$.

Os valores de tamanho de partículas e densidade obtidos no presente experimento (Tabelas 3 e 4), estão aproximados dos valores apresentados na Anexo $\mathrm{C}$, originados no levantamento de índices técnicos de silagem de capim. Assim, demostra que as condições do experimento estão próximas das encontradas no setor privado, com ressalva do grau de eficiência de cada unidade produtiva visitada durante esse levantamento de dados.

Holmes \& Muck (1999) mencionam que para se obter benefícios da compactação, são necessário $225 \mathrm{~kg}$ de matéria seca de silagem por $\mathrm{m}^{3}$, como valor de densidade. Contudo, no presente experimento, de acordo com as característica da planta ensilada, o valor da densidade próximo a $150 \mathrm{~kg}$ de matéria seca de silagem por $\mathrm{m}^{3}$, apresentou a silagem com parâmetros fermentativos satisfatórios. Analisando a Figura 6 verifica-se que teores de matéria seca superiores a $25 \%$, possibilitaram a ocorrência de densidades próximas de $150 \mathrm{~kg}$ de matéria seca de silagem por $\mathrm{m}^{3}$. 
A máxima densidade $\left(\mathrm{kg} \mathrm{MS} . \mathrm{m}^{-3}\right)$ prevista pelo modelo pode ser descrita através da derivada da equação original (Figura 6), como apresentada a seguir:

Pto máximo $=-\hat{a}_{1} / 2 . \hat{a}_{2}$

Ao adotar-se essa nova equação, obteve-se que o ponto de máxima densidade de $\mathrm{MS}^{-3} \mathrm{~m}^{-3}$, seria atingido quando o teor de matéria seca fosse de $33,3 \%$, equivalente a $159,5 \mathrm{~kg}^{\mathrm{MS}} \mathrm{M}^{-3}$.

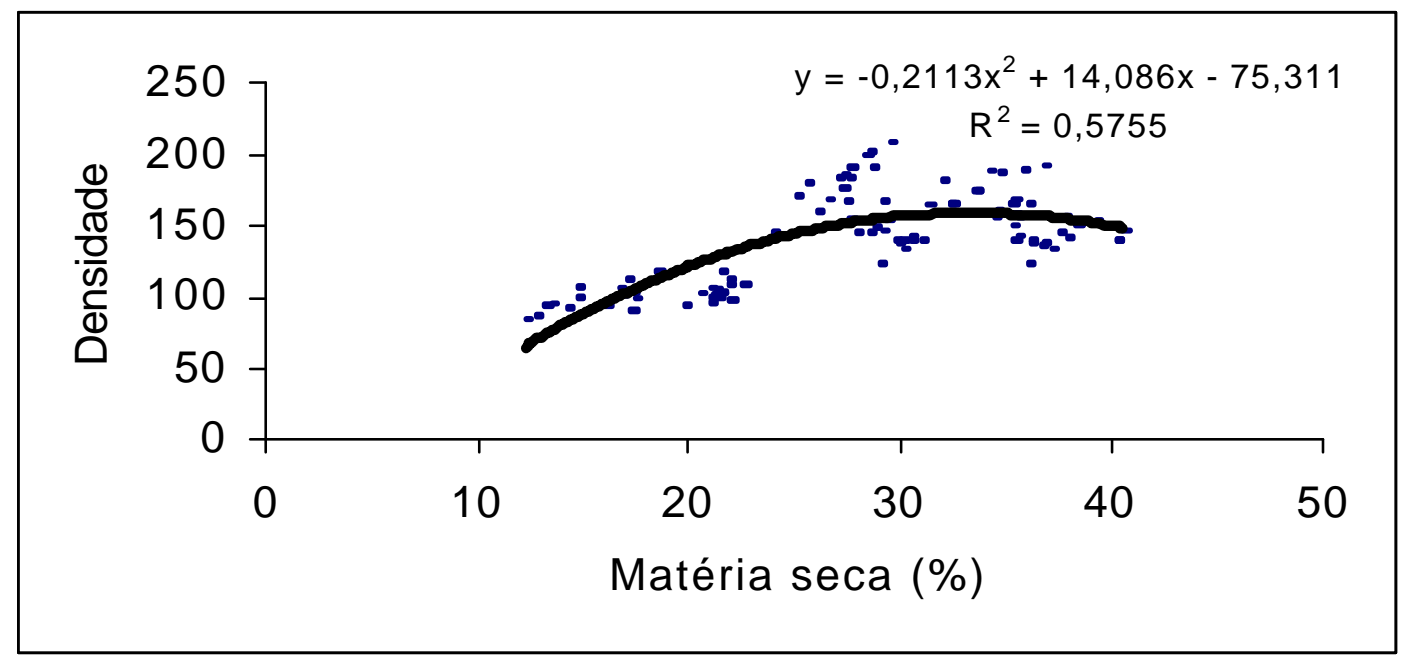

Figura 6 - Efeito do teor de matéria seca da silagem em relação a densidade $\left(\mathrm{kg}\right.$ de $\mathrm{MS} \cdot \mathrm{m}^{-3}$ ) da silagem de capim Tanzânia.

\subsubsection{Condutividade elétrica}

A mensuração da condutividade elétrica (CE) do material em análise é expressa em ì $\mathrm{S} / \mathrm{cm}$, a qual fornece a intensidade da ruptura celular pelo corte e picagem da forragem. Segundo Pauly (1999) e Kraus et al. (1997), o efeito do processamento físico resultante da picagem da forragem, o que reflete na drenagem do conteúdo celular devido a ruptura da parede celular da planta, pode ser quantificado por meio da determinação da condutividade elétrica (CE), 
o qual corresponde a contribuição iônica do conteúdo celular extravasado pela planta. Portanto, amostras com maior escoamento de conteúdo celular apresentaram maior CE, representando a extensão do prejuízo causado pela ruptura celular das plantas.

Os valores obtidos com a forragem e a silagem estão apresentados nas Tabelas 3 e 4 . Os valores encontrados no presente experimento estão mais elevados do que os valores de CE apresentados por Castro et al. (2001), o qual trabalhou com silagem de Tifton com diferentes teores de MS, e obteve o valor médio de 886 ì s/cm entre todos os tratamentos. Esse diferencial no valor da CE pode ser atribuído principalmente a característica de corte da colhedora utilizada, ao nível de adubação, e também à características morfológicas e fisiológicas da plantas em questão.

Houve significância $(P<0,05)$ no efeito estação do ano (EST) na condutividade elétrica (CE). Verifica-se que o valor da CE para os tratamentos no corte de verão foram mais elevados que para os mesmos tratamentos no colhidos no inverno. Esse fato pode ser explicado pela picagem mais fina da forragem, sendo verificado na medida do tamanho das partículas, através da metodologia das peneiras da "Penn State Particle Size Separator" (Lammers, 1996), que apresentou maior a proporção de material com diâmetro superior à $1,905 \mathrm{~cm}$ durante 0 corte de inverno em relação ao corte de verão (Figura 7). Esse fato pode ser explicado pelo maior teor de matéria seca dos tratamentos no corte no inverno, o que provavelmente diminuiu a eficiência de corte pela colhedora, devido a estrutura mais rígida da forragem com teor de MS mais elevado. Essa tendência também foi verificada no tratamento com préemurchecimento da forragem (PE), no qual o maior teor de MS também refletiu na maior porcentagem de partículas retidas na peneira de $1,905 \mathrm{~cm}$ de diâmetro, em comparação com o tratamento com a forragem contendo a umidade original (MO). Concordando, Pauly et al. (1999), testando três métodos de corte de forragem, também obtiveram aumento da CE com o menor tamanho de partícula. Esse fato também foi verificado por Shinners et al. (2000), que 
verificaram a tendência de aumento no valor da CE a medida que a partícula foi reduzido em tamanho.

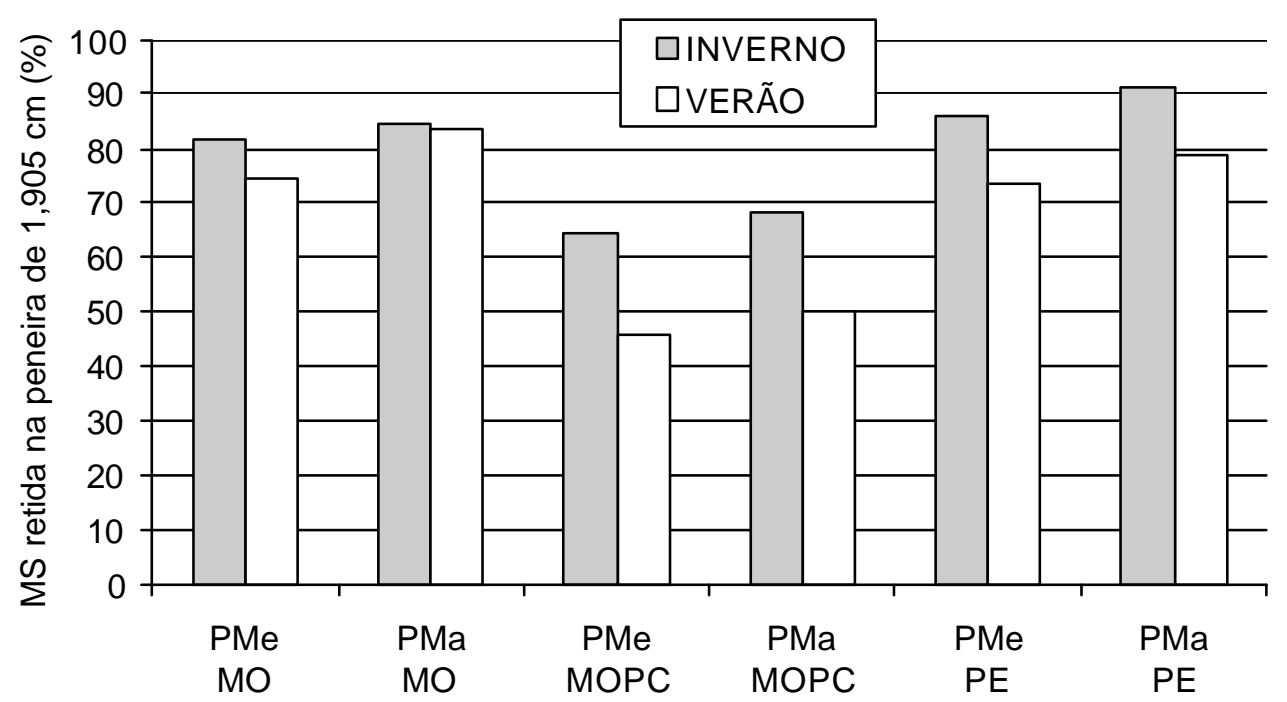

Figura 7 - Porcentagem de retenção de matéria seca na peneira de 1,905 cm de diâmetro, nas silagens de capim Tanzânia ensiladas com a umidade original (MO), pré-emurchecidas e ou recebendo polpa cítrica (MOPC), nos tamanhos de partícula maior (PMa) e menor (PMe), nos cortes de verão e inverno.

A alteração no teor de matéria seca (TMS), também apresentou efeito significativo $(P<0,05)$, sendo o maior valor de $C E$ encontrado no tratamento $P E$ (1887ì S.cm ${ }^{-1}$ ) em relação ao MO (1752 ì S.cm ${ }^{-1}$ ) e ao MOPC (1635 ì S.cm), provavelmente devido a maior líse da membrana celular ocasionada pelo emurchecimento da forragem, o que promoveu o maior extravasamento de conteúdo celular. Castro et al. (2001) também observaram o aumento significativo no valor da CE quando promoveram emurchecimento e elevação do teor de MS de $25 \%$ para $65 \%$, em silagens de Tifton.

$O$ inclusão do inoculante bacteriano (INOC) não resultou em efeito significativo $(P>0,05)$ na mensuração da $C E$ na silagem pós abertura dos silos experimentais. Esse fato reflete que as bactérias $L A B$ inoculadas não atuaram 
de maneira a aumentar a líse das células vegetais na silagem, em comparação com o tratamento controle sem a inoculação de bactérias exógenas.

Foi verificado a interação tripla entre EST x TMS X PART $(P<0,05)$, o que é devido ao fato que nos tratamentos $\mathrm{MO}$ e PE, na estação de inverno e verão, houve o aumento da $\mathrm{CE}$, quando o tamanho de partícula foi reduzido, enquanto que, na estação de verão, com o tratamento de MOPC, as partículas de tamanhos maiores (PMa) e menores (PMe) não apresentaram diferença significativa $(P>0,05)$ em relação a $C E$, conforme ilustrado na Tabela 5 . Isto pode ser explicado pelo elevada inclusão de PCP (na taxa de $15 \%$ de PCP em relação ao peso da forragem fresca), o que adicionou uma elevada quantidade de solutos no material, e mascarando o efeito da maior ruptura celular, proporcionado pelo menor tamanho de partícula.

Tabela 5. Médias de condutividade elétrica (CE, ì S. $\mathrm{cm}^{-1}$ ) para os efeitos do teor de matéria seca (TMS) e do tamanho de partícula, das silagens de capim Tanzânia, produzidas no inverno e no verão.

\begin{tabular}{|c|c|c|}
\hline \multirow{2}{*}{ Teor de MS (TMS) } & \multicolumn{2}{|c|}{ Partícula (PART) } \\
\hline & $\mathrm{PMe}$ & PMa \\
\hline \multicolumn{3}{|l|}{ Inverno } \\
\hline $\mathrm{MO}$ & $1500^{\mathrm{aA}}$ & $1380^{\mathrm{aB}}$ \\
\hline MOPC & $1475^{\mathrm{aA}}$ & $1366^{\mathrm{aB}}$ \\
\hline PE & $1567^{\mathrm{bA}}$ & $1421^{\mathrm{aB}}$ \\
\hline Média & $1514^{\mathrm{A}}$ & $1389^{\mathrm{B}}$ \\
\hline \multicolumn{3}{|l|}{ Verão } \\
\hline MO & $2141^{c C}$ & $1991^{\mathrm{CD}}$ \\
\hline MOPC & $1849^{d C}$ & $1851^{\mathrm{cD}}$ \\
\hline PE & $2403^{e C}$ & $2159^{e D}$ \\
\hline Médi & $2131^{C}$ & $2000^{\mathrm{D}}$ \\
\hline
\end{tabular}

(MO - forragem ou silagem com a umidade original; MOPC - forragem ou silagem com adição de polpa cítrica peletizada; PE - forragem ou silagem pré-emurchecida; PMa - partícula maior; PMe - partícula menor; TMS - efeito da alteração no teor de matéria seca; PART - efeito do tamanho de partícula)

Letras maiúsculas diferentes na linha, e letras minúsculas diferentes na coluna indicam diferença significativa $(P<0,05)$. 
Na Figura 8 , as observações foram separadas em dois conjuntos de dados, silagem na matéria original $(\mathrm{MO})$ + silagem pré-emurchecida $(\mathrm{PE})$, e a silagem contendo a adição de PCP (MOPC). Isto foi devido ao fato de que o tratamento com a inclusão de PCP alterarou a estrutura física do material analisado. Observa-se o efeito linear entre a porcentagem de partículas com diâmetro maior de $1,905 \mathrm{~cm}$ e o respectivo valor de CE, entretanto obteve-se um $R^{2}$ relativamente baixo para os dados de $M O+P E\left(R^{2}=59,25\right)$. Esse fato sugere que a classificação de tamanho de partícula com diâmetro acima de $1,905 \mathrm{~cm}$ é uma medida deficiente quando objetiva-se mensurar o efeito do corte e picagem, assim como o extravasamento de líquido intracelular. Assim sendo, a metodologia de estratificação em peneiras "Penn State Particle Size Separator" (Lammers, 1996), não traduz adequadamente as características de picagem das colhedoras disponíveis no mercado, sendo que a inclusão de uma peneira de diâmetro próximo a $4 \mathrm{~cm}$ poderá auxiliar no incremento de sensibilidade da avaliação.

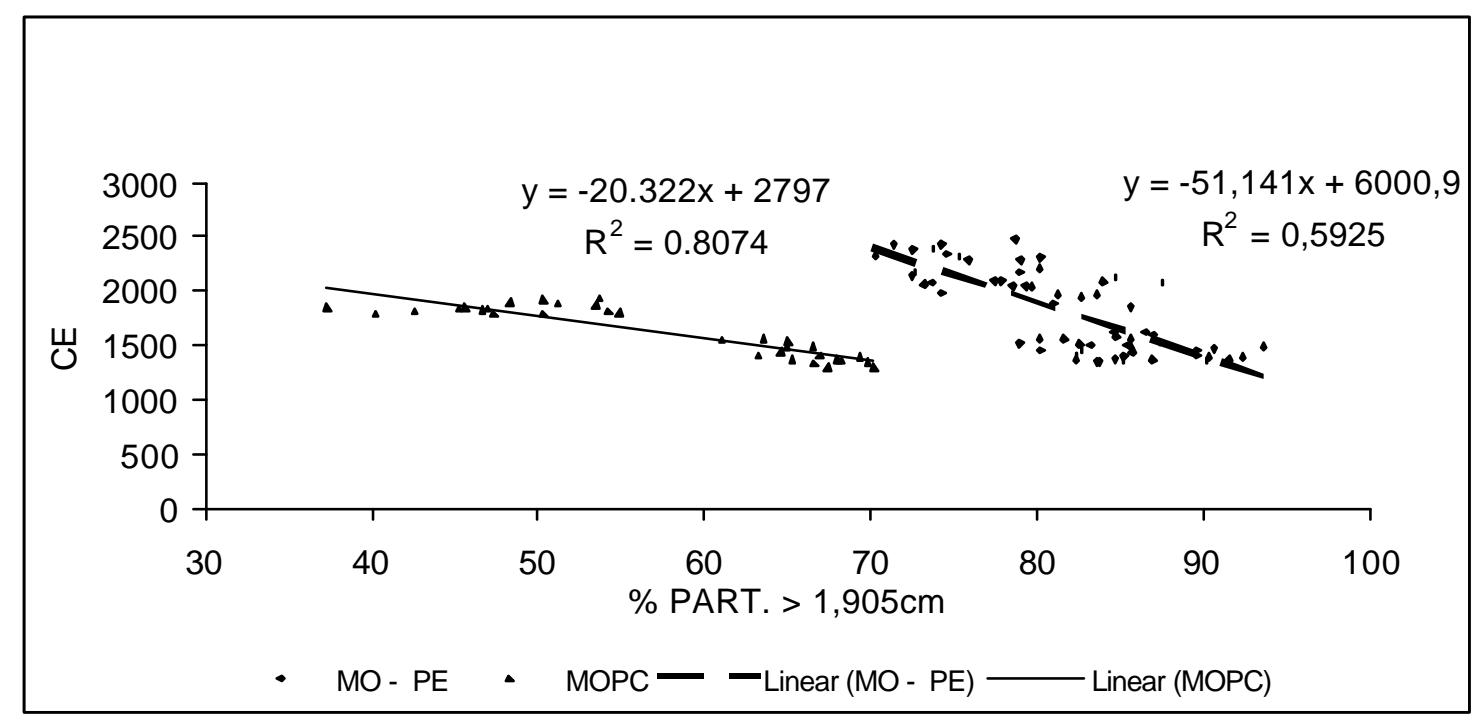

Figura 8 - Relação entre a porcentagem do material retido na peneira de 1,905 cm de diâmetro, em função da condutividade elétrica (CE, ì S. $\left.\mathrm{cm}^{-1}\right)$. 


\subsubsection{Perdas por Efluente}

Os valores de produção de efluente dos respectivos tratamentos estão apresentados nas Tabela 3 e 4, sendo mensurados em $\mathrm{kg}$ de efluente por tonelada de material ensilado. Na literatura, a produção de efluente, é normalmente, expressa na unidade de litros por tonelada de material ensilado (Alli et al., 1985; Jones \& Jones, 1995; Reynolds \& Williams, 1995; Jones \& Jones, 1996; Fransen \& Strubi, 1998; Haigh, 1999), contudo alguns trabalhos apresentam a medida em $\mathrm{kg}$ de efluente por tonelada de material ensilado (Keady \& O'Kiely, 1996; O'Donnell et al. , 1997).

Haigh (1999) propôs uma equação para estimativa da produção de efluente em relação ao teor de matéria seca (MS), baseadas em 33 silagens (Figura 9). No presente experimento foi confeccionada uma equação de estimativa da produção de efluente em função do teor de matéria seca (Figura 10), sendo encontrado uma função exponencial, conforme verificado por Haigh (1999).

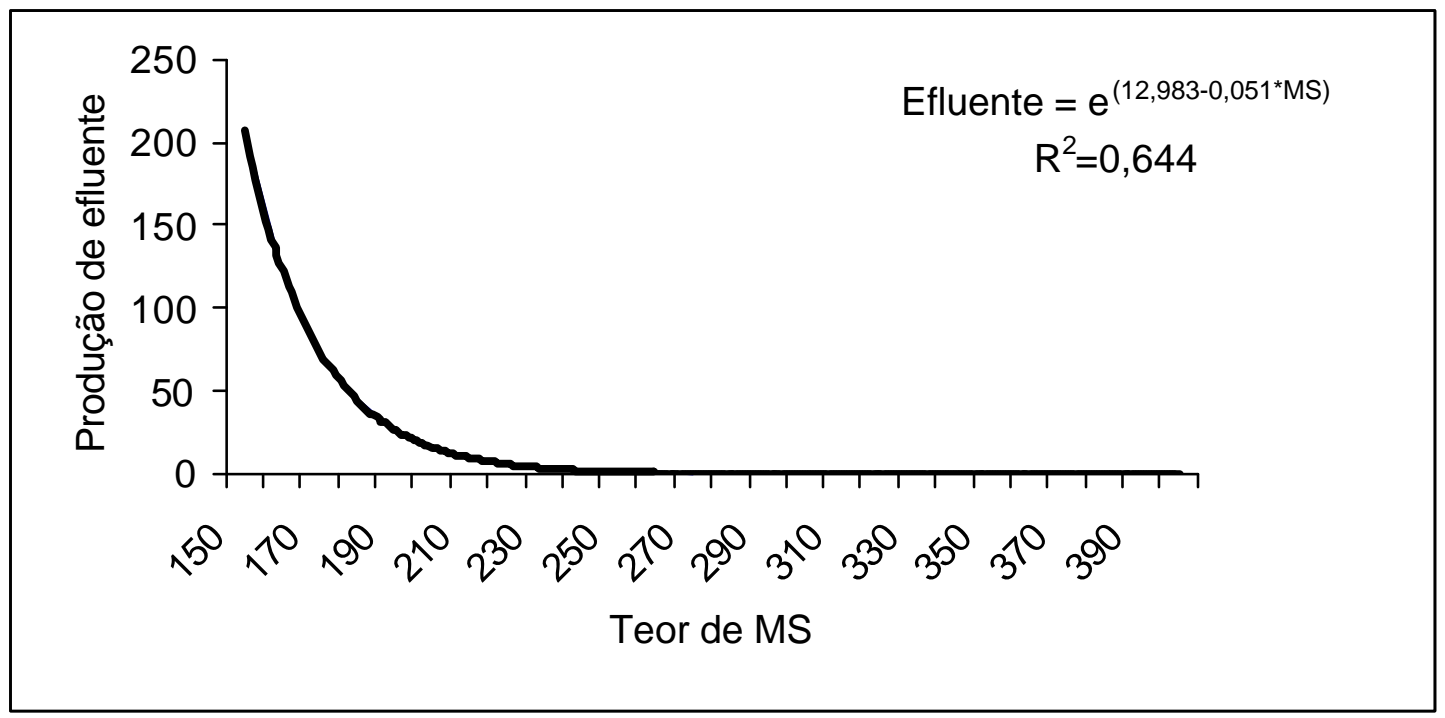

Figura 9 - Equação de Haigh (1999) na determinação da produção de efluente $\left(\right.$ L. $\left.^{-1}\right)$ em relação ao teor de matéria seca $\left(\mathrm{g} \cdot \mathrm{kg}^{-1}\right)$. 


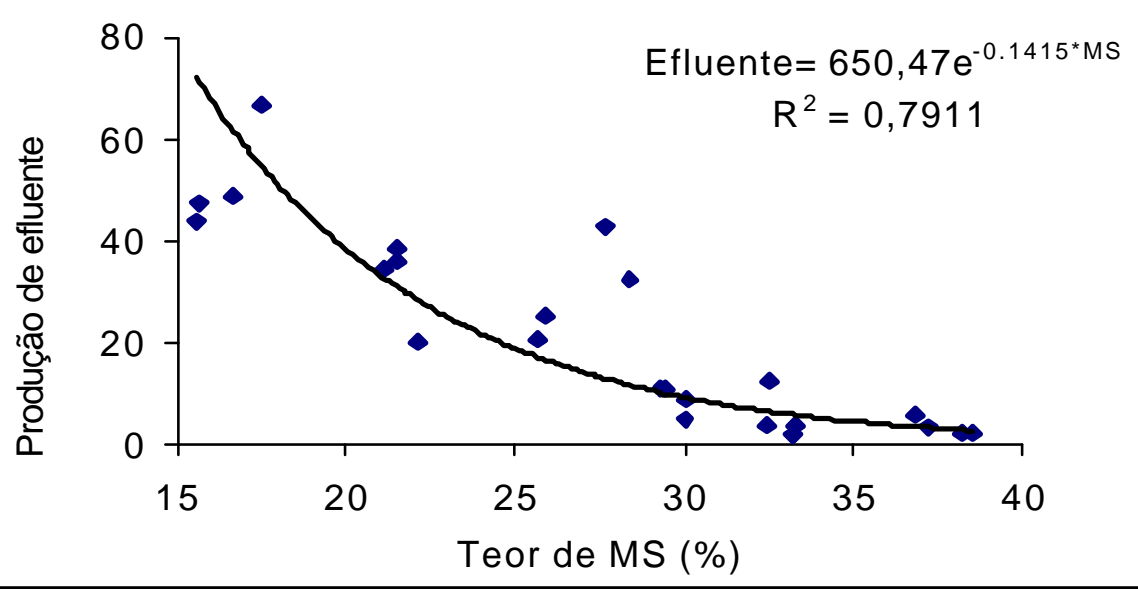

Figura 10 - Equação para estimativa da produção de efluente $\left(\mathrm{kg} \cdot \mathrm{t}^{-1}\right.$ de forragem fresca) em relação ao teor de matéria seca $\left(\mathrm{g} \cdot \mathrm{kg}^{-1}\right)$ em silagens de capim Tanzânia

Verifica-se que nas Figuras 9 e 10 foi constatado efeito exponencial, sendo a produção de efluente diminuída conforme o teor de matéria seca é elevada. Houve significância $(P<0,05)$ para o efeito de estação do ano (EST) e da alteração do teor de matéria seca (TMS), sobre a produção de efluente, contudo a inclusão de inoculante bacteriano (INOC) e a alteração do tamanho de partícula não apresentaram significância $(P>0,05)$ sobre esse parâmetro, conforme Tabelas 3 e 4.

A significância estatística $(P<0,05)$ dos efeitos de EST e TMS, foi devida a elevação nos teores de matéria seca, resultante do efeito do corte de inverno onde a forragem se apresentava com 0 teor de umidade inferior quando comparada ao verão. $O$ efeito do teor de matéria seca na produção de efluente é amplamente citado na literatura, sendo que diversos autores trabalhando tanto com leguminosas quanto com gramíneas, obtiveram diminuição da produção de efluente a medida que o teor de matéria seca aumentou, e verificaram que a produção de efluente foi praticamente nula quando o teor de matéria seca elevou-se para limiares ao redor de $28 \%$ (Alli et al., 1985; McDonald, 1991; Jones \& Jones, 1995; Reynolds \& Williams, 1995; Keady \& 
O'Kiely, 1996; Jones \& Jones, 1996; O’Donnell et al. , 1997; Fransen \& Strubi, 1998; Haigh, 1999). A correção do teor de matéria seca através da utilização de aditivos aborventes de umidade, proporcionou a diminuição de efluentes, como visto no presente experimento (Tabela 3 e 4). Isso está condizente com os resultados obtidos por Aguiar et al. (2001), que incluíram três níveis crescentes de polpa cítrica peletizada (0,5 e 10\%) na massa ensilada e constatou a diminuição na produção de efluente. Nesse mesmo sentido, McDonald (1991), Jones \& Jones (1996), e Fransen \& Strubi (1998), também mencionaram o efeito da menor produção de efluente pela inclusão de aditivos absorventes que promoveram a elevação do teor de matéria seca.

Contudo, segundo Balsalobre et al. (2001) e Jones \& Jones (1995), outros fatores devem ser considerados na avaliação de perdas por efluente, podendo destacar características como o tipo e dimensionamento do silo, pressão de compactação e homogeneidade de aplicação de aditivos.

$\mathrm{Na}$ análise estatística dos dados foi constatada a interação tripla significativa $(P<0,05)$ para os efeitos de TMS $\times$ PART $\times$ EST (Tabela 6$)$. A interpretação dessa interação consiste no fato que na silagem proveniente dos tratamentos $\mathrm{MO}$ e $\mathrm{PE}$, no corte de inverno, o menor tamanho de partícula (PMe) produziu maior quantidade de efluente do que o maior tamanho (PMa). Seguindo a mesma tendência, no corte de verão, a partícula menor (PMe) levou a maior produção de efluente nos tratamentos MO e MOPC. No tratamento MOPC no inverno, não houve diferença significativa entre a PMe e PMa. Contudo, a PMa apresentou maior produção de efluente que a Pme, no tratamento PE, durante o verão, conflitando com a tendência verificada nos demais tratamentos. 
Tabela 6. Médias da produção de efluente para os efeitos da alteração do teor de matéria seca (TMS), do tamanho de partícula (PART) e da estação do ano (EST), na silagem de capim Tanzânia.

\begin{tabular}{llcc}
\hline & & \multicolumn{2}{c}{ Estação } \\
\cline { 2 - 4 } TMS & PART & Inverno & Verão \\
\hline MO & PMe & $10,97^{\mathrm{Ad}}$ & $45,74^{\mathrm{Bc}}$ \\
MO & PMa & $7,1^{\mathrm{Ac}}$ & $57,87^{\mathrm{Bd}}$ \\
MP & $\mathrm{PMe}$ & $2,91^{\mathrm{Aab}}$ & $37,68^{\mathrm{Bc}}$ \\
MP & $\mathrm{PMa}$ & $2,82^{\mathrm{Aab}}$ & $22,96^{\mathrm{Ba}}$ \\
$\mathrm{PE}$ & $\mathrm{PMe}$ & $4,64^{\mathrm{Ab}}$ & $27,27^{\mathrm{Bab}}$ \\
PE & $\mathrm{PMa}$ & $2,18^{\mathrm{Aa}}$ & $37,30^{\mathrm{Bc}}$ \\
\hline
\end{tabular}

(MO - forragem ou silagem com a umidade original; MOPC - forragem ou silagem com adição de polpa cítrica peletizada; PE - forragem ou silagem pré-emurchecida; PMa - partícula maior; PMe - partícula menor; TMS - efeito da alteração no teor de matéria seca; PART - efeito do tamanho de partícula)

Letras maiúsculas diferentes na linha, e letras minúsculas diferentes na coluna indicam diferença significativa $(P<0,05)$.

Seria esperado que a silagem originada com o menor tamanho de partícula (PMe) produzisse mais efluente que a silagem com maior tamanho (PMa), explicado pela maior ruptura celular causada pelo processamento mecânico, resultados que podem ser evidenciados pela condutividade elétrica (CE) (Tabelas 3 e 4). Esse fato está de acordo com o observado por Aguiar et al. (2001), que analisaram silagem de Tanzânia com três tamanhos de partículas, e constataram que os menores tamanhos de partículas foram aqueles relacionados com aumentos na produção de efluente.

\subsubsection{Perdas por gases}

As perdas por gases estão associadas ao perfil de fermentação ocorrido na silagem, sendo que as menores perdas são ocasionadas pelas bactérias homofermentativas utilizando glucose como substrato para a síntese de lactato. Maiores produções de gases estão associadas com as bactérias 
heterofermentativas, enterobactérias, destacando a fermentação butírica, promovida por bactérias do gênero Clostrídium $s p$.

A produção de gases originadas dos tratamentos experimentais está apresentada nas Tabelas 3 e 4, sendo quantificada em porcentagem da matéria seca. Os resultados apresentados mostram que houve efeito significativo de estação $(P<0,05)$, havendo no corte de inverno menor produção média de gás $(3,02 \%)$ em relação ao corte de verão (5,32\%). O efeito da alteração no teor de matéria seca (TMS) também obteve significância $(P<0,05)$, sendo que 0 tratamento com adição da polpa cítrica peletizada (MOPC) produziu a menor quantidade de gás $(2,86 \%)$, seguido pelo tratamento com pré-emurchecimento (PE) $(4,35 \%)$, e pelo tratamento contendo a umidade original da forragem (MO) $(5,31 \%)$. A maior produção de gás para os tratamentos com umidade mais elevada e sem adição de polpa cítrica peletizada, se deve a maior incidência de fermentações indesejáveis, características que podem ser constatadas pelos teores de nitrogênio amoniacal e pH apresentados nas Tabelas 3 e 4.

Não houve efeito significativo $(P<0,05)$ de tamanho de partícula com relação a produção de gás, sendo que a produção de gás se comportou de forma similar para os dois tamanhos de partícula (PMe e PMa $=4,2 \%$ ). Aguiar et al. (2001) trabalhando com silagem de capim Tanzânia, observaram menor produção de gás quando houve a diminuição do tamanho de partícula, entretanto, ao analisar os dados considerando a amplitude de tamanhos de partículas similares ao presente experimento, verificourse que os autores também não encontraram efeito significativo, seguindo que haja um limiar de tamanhos de partícula a partir do qual as perdas gasosas se intensificam.

Com relação a adição de inoculante bacteriano, houve efeito significativo $(P<0,05)$, sendo que o tratamento com a inoculação $(C)$ apresentou menor perdas em relação ao tratamento sem a inoculação (S), com os respectivos valores de 3,86 e 4,83\%. Esses dados concordam com aqueles observados por Cai et al. (2001), onde ao utilizarem cepas de L. plantarum, obtiveram redução na produção de gás, tanto para silagem de alfafa (6,3 para 4,1 L.kg MS ${ }^{-1}$ ), 
quanto na silagem de azevém (5,0 para 3,7 L.kg MS ${ }^{-1}$ ). Contudo, mesmo sem efeito em outros parâmetros fermentativos ( $\mathrm{pH}$ e NA), as bactérias homofermentativas inoculadas propiciaram a menor produção de gás, provavelmente em função da fermentação da glicose em ácido láctico, e do fato dessa reação não produzir compostos voláteis, conforme discutido por McDonald et al. (1991) e Balsalobre et al. (2001).

A análise estatística constatou a interação dupla significativa $(P<0,05)$ para os efeitos de EST $\times$ INOC, fato devido ao tratamento da inclusão do inoculante não ter provido diferença significativa entre seus dois níveis, com (C) e sem (S), no corte de verão; tendo entretanto, no corte de inverno, apresentado maior produção de gás, na ausência de inoculação bacteriana, conforme mostrado na Tabela 7. Esse fado contribui para a hipótese de que no verão a população bacteriana epifítica poderia ser suficiente para o adequado processo fermentativo, enquanto que no inverno, a adição de uma população exógena, poderia apresentar resposta positiva na fermentação, com a menor produção de gás.

Tabela 7. Médias da estimativa da produção de gás (\% da matéria seca) para os efeitos do inoculante bacteriano em silagens de capim Tanzânia, produzidas no verão e no inverno.

\begin{tabular}{lcc}
\hline & \multicolumn{2}{c}{$\mathrm{INOC}$} \\
\cline { 2 - 3 } Estação (EST) & $\mathrm{C}$ & $\mathrm{S}$ \\
\hline Inverno & $2,38^{\mathrm{Aa}}$ & $3,66^{\mathrm{Ba}}$ \\
Verão & $5,34^{\mathrm{Aa}}$ & $5,31^{\mathrm{Aa}}$ \\
\hline- com inoculante bacteriano; $\mathrm{S}$ & - sem inoculante bacteriano; INOC - efeito \\
oculante bacteriano) & \\
etras maiúsculas diferentes na linha, e letras minúsculas diferentes na coluna indicam \\
erença significativa $(\mathrm{P}<0,05)$.
\end{tabular}

Houve interação tripla significativa $(P<0,05)$ para os efeitos de TMS $x$ PART x EST, sobre a produção de gás, devido a variável partícula menor $(\mathrm{PMe})$, ter promovido diferença significativa $(\mathrm{P}<0,05)$ apenas no tratamento $\mathrm{MO}$, no corte de verão; sendo que nos demais tratamentos, MOPC e PE no verão, e 
MO, MOPC e PE no inverno, não foram observadas diferenças entre os tamanhos de partículas, conforme demonstrado nas Tabelas 8 e 9. A maior produção de gás observada com a redução do tamanho da partícula no tratamento MO (Tabela 9), ocorreu, provavelmente, em função da maior ruptura da parede celular e escoamento de conteúdo celular, conforme verificado na mensuração da CE (Tabelas 3 e 4). O elevado teor de umidade da forragem (15,6\% de MS), determinou um ambiente mais propício para a ocorrência de fermentações indesejáveis. Entretanto a atividade de água (AW) não apresentou alteração pela diminuição do tamanho da partícula, no tratamento em discussão (Tabelas 3 e 4). Esse efeito da maior intensidade de atuação dos Clostridium sp no tratamento $\mathrm{MO}$, sob a condição de partícula menor (PMe), durante o verão, é constatado pelos maiores $\mathrm{pH}$ e $\mathrm{NA}$, em relação ao tratamento $\mathrm{MO}$, com a partícula maior (PMa), na mesma estação. Contudo, esse fato também pode ter sido um agravado pelo menor teor de matéria seca original da forragem no verão, para o tratamento PMe (15,6\% de MS), em relação ao tratamento com partícula maior (17,1\% de MS).

Tabela 8. Médias da estimativa da produção de gases (\% da matéria seca) para os efeitos do tamanho de partícula (PART) e da alteração do teor de matéria seca (TMS), em silagens de capim Tanzânia colhidas durante o inverno.

\begin{tabular}{lcc}
\hline TMS & Particula menor (PMe) & Partícula maior (PMa) \\
\hline MO & $3,3^{\mathrm{Aa}}$ & $3,4^{\mathrm{Aa}}$ \\
MOPC & $2,6^{\mathrm{Aa}}$ & $3,1^{\mathrm{Aa}}$ \\
PE & $2,3^{\mathrm{Aa}}$ & $3,4^{\mathrm{Aa}}$
\end{tabular}

( $\mathrm{MO}$ - forragem ou silagem com a umidade original; MOPC - forragem ou silagem com adição de polpa cítrica peletizada; PE - forragem ou silagem pré-emurchecida; PMa - partícula maior; PMe - partícula menor; TMS - efeito da alteração no teor de matéria seca)

Letras maiúsculas diferentes na linha, e letras minúsculas diferentes na coluna indicam diferença significativa $(\mathrm{P}<0,05)$. 
Tabela 9. Médias na produção de gases (\% da matéria seca) para os efeitos do tamanho de partícula (PART) e da alteração do teor de matéria seca (TMS), em silagens de capim Tanzânia colhidas, durante o verão.

\begin{tabular}{lcc}
\hline TMS & Particula menor (PMe) & Partícula maior (PMa) \\
\hline MO & $8,80^{\mathrm{Aa}}$ & $5,73^{\mathrm{Ba}}$ \\
MOPC & $2,75^{\mathrm{Ab}}$ & $2,96^{\mathrm{Ab}}$ \\
PE & $5,24^{\mathrm{Ac}}$ & $6,45^{\mathrm{Ac}}$
\end{tabular}

(MO - forragem ou silagem com a umidade original; MOPC - forragem ou silagem com adição de polpa cítrica peletizada; PE - forragem ou silagem pré-emurchecida; PMa - partícula maior; PMe - partícula menor; TMS - efeito da alteração no teor de matéria seca)

Letras maiúsculas diferentes na linha, e letras minúsculas diferentes na coluna indicam diferença significativa $(P<0,05)$.

\subsubsection{Estabilidade aeróbica}

O conceito de estabilidade aeróbica adotado no presente experimento foi caracterizado pela temperatura acumulada durante 5 dias após a abertura dos silos experimentais, conforme sugerido por O'Kiely et al. (1999). Maiores acúmulos de temperatura representam que houve maior aquecimento da massa ensilada após a abertura, sendo reflexo da maior intensidade de reações promovidas pelos microrganismos oportunistas ao ambiente aeróbico, os quais se utilizam dos nutrientes disponíveis na silagem, provocando assim, perdas no valor nutritivo da silagem (McDonald et al., 1991; Keady \& O'Kiely, 1996; Kung \& Ranjit, 2000; Balsalobre et al., 2001).

Os resultados dos tratamentos e dos respectivos acúmulos de temperatura nos cinco primeiros dias após abertura dos silos experimentais, estão apresentadas nas Tabelas 3 e 4 . Houve efeito de estação $(P<0,05)$, sendo as médias das temperaturas acumuladas na silagem proveniente do inverno, superiores aquelas do corte de verão $\left(151,85^{\circ} \mathrm{C}\right.$ e $95,07^{\circ} \mathrm{C}$, respectivamente). Fato que é provavelmente devido as condições climáticas no momento da abertura do silo, uma vez que a silagem produzida no inverno foi 
aberta no mês de novembro, enquanto que no corte de verão, os silos foram abertos no mês de junho, períodos em que as temperaturas médias do ambiente foram de $26,0^{\circ} \mathrm{C}$ e $20,6^{\circ} \mathrm{C}$, respectivamente. Assim, a temperatura do ambiente foi condicionante do aumento no processo de deterioração e nas perdas pós-abertura dos silos experimentais, estando de acordo com os relatos de McDonald et al. (1991), Ashbell \& Weinberg (1999) e Kung \& Ranjit (2000).

Foi verificado efeito significativo para a alteração do teor de matéria seca (TMS, $\mathrm{P}<0,05$ ), com a maior temperatura acumulada observada no tratamento contendo PCP (MOPC) e aquele submetido ao pré-emurchecimento (PE), em relação ao tratamento $\mathrm{MO}$. No tratamento MOPC, esse fato pode ser devido a maior concentração de carboidratos residuais, conforme discutido por VEIGA et al. (2000) e Muhlbach (1999), que relatam altas concentrações de carboidratos solúveis para a polpa cítrica, aproximando-se de $50 \%$ na matéria seca. Com relação ao tratamento $\mathrm{PE}$, a maior temperatura acumulada em relação ao $\mathrm{MO} e$ similar ao MOPC $(P>0,05)$, poderia ser explicado também pelos teores de carboidratos solúveis residuais superiores ao tratamento $\mathrm{MO}$, apesar do tratamento PE Ter apresentado menor pH em relação ao tratamento MO. Esse mesmo cenário foi verificado por Berto \& Muhlbach (1997), em avaliações de aveia preta, sendo que o tratamento com pré-emurchecimento $(35,7 \% \mathrm{MS})$ proporcionou menor $\mathrm{pH}$ e maior teor de carboidratos residuais, comparado com o tratamento não emurchecido (18,6\% MS). Entretanto, no clássico trabalho de Charmley \& Thomas (1987), são apresentadas perdas por respiração, durante 65 horas de secagem ao campo, na ordem de $62,7 \mathrm{~g} \cdot \mathrm{kg}^{-1}$ de matéria seca e de $54,1 \mathrm{~kJ} \cdot \mathrm{mJ}^{-1}$ de energia. As perdas de nutrientes solúveis são devidas a respiração de carboidratos pela planta durante o processo de emurchecimento no campo, o que diminui a quantidade de carboidratos residuais. Contudo, no presente experimento, as perdas devem ter sido reduzídas, devido ao curto período de exposição ao emurchecimento (6 horas). Segundo McDonald \& Henderson (1981), o teor de carboidratos solúveis tendem diminuir após 48 horas de emurchecimento, pois as perdas devidas a respiração aeróbica são 
compensadas pela atividade enzimática, que promove 0 hidrólise de polissacarídeos (hemicelulose) em açucares solúveis. Em outro sentido, os mesmos autores, destacam trabalhos que utilizaram $\mathrm{C} 14$, e verificaram que ocorreu atividade fotossintética durante as primeiras 24 horas na forragem ceifada. Contudo, é necessário cautela nessa argumentação, visto que em condições de campo essa produção fotossintetica é difícil de ser mensurada, uma vez que a radiação solar apenas atinge a camada superficial da forragem exposta ao emurchecimento.

Outra hipótese para explicar a pior estabilidade aeróbica do tratamento pré-emurchecido $(\mathrm{PE})$ em comparação àsilagem proveniente da forragem com a umidade original (MO), pode ser devida a elevação do teor de matéria seca (MS) com o pré-emurchecimento. O perfil fermentativo das silagens com alterações no teor de matéria seca, altera as concentrações de ácido acético e lático, o que poderia influenciar a colonização de microrganismos aeróbicos pós-abertura, pelas características anti-microbianas dos ácidos em discussão. Essa suposição é suportada pelos relatos de relatos apresentados por Weinberg \& Muck (1996), Kung (2000), Kung \& Ranjit (2000), e Filya et al. (2000). Entretanto, essa hipótese discorda do experimento de Berto \& Muhlbach (1997), onde foi verificado que o tratamento com o emurchecimento proporcionou um menor concentração total de ácidos, além de diminuir a concentração de ácido acético e aumentar a relação ácido lático : ácido acético.

Dessa forma, torna-se necessária a caracterização das concentrações dos respectivos ácidos e as concentrações dos carboidratos residuais, de forma a explicar a menor estabilidade aeróbica nos tratamentos préemurchecido (PE) em relação ao tratamento com a forragem ensilada na umidade original (MO) (Tabela 10). 
Tabela 10. Médias da temperatura acumulada nas silagens pós-abertura, para os efeitos da alteração do teor de matéria seca (TMS) e da estação do ano (EST).

\begin{tabular}{llll}
\hline & \multicolumn{3}{c}{ Estação } \\
\cline { 2 - 3 } TMS & Inverno & Verão & Média \\
\hline MO & $152,2^{\mathrm{Ac}}$ & $89,1^{\mathrm{Ba}}$ & $120,6^{\mathrm{a}}$ \\
MPC & $151,2^{\mathrm{Ac}}$ & $97,7^{\mathrm{Bb}}$ & $125,3^{\mathrm{b}}$ \\
PE & $152,2^{\mathrm{Ac}}$ & $98,4^{\mathrm{Bb}}$ & $124,5^{\mathrm{b}}$
\end{tabular}

( $M \overline{\mathrm{OO}}$ - forragem ou silagem com a umidade original; MOPC - forragem ou silagem com adição de polpa cítrica peletizada; PE - forragem ou silagem pré-emurchecida; TMS - efeito da alteração no teor de matéria seca)

Letras maiúsculas diferentes na linha, e letras minúsculas diferentes na coluna indicam diferença significativa $(P<0,05)$.

Houve também efeito significativo de tamanho de partícula $(P<0,05)$, sendo que os tratamentos com partículas menores (PMe) apresentaram menor temperatura acumulada $\left(121,8^{\circ} \mathrm{C}\right)$ quando comparado às partícula maiores (PMa) $\left(125,1^{\circ} \mathrm{C}\right)$, portanto apresentando melhor estabilidade aeróbica. Esse fato poderia ser atribuido a suposta maior capacidade de reacomodação das partículas menores (PMe), após a abertura e descompactação, evitando com isso a plena aeração da silagem. Contudo não foram encontrados relatos desse efeitos na literatura consultada.

O inoculante bacteriano (INOC) não apresentou efeito significativo $(P>0,05)$. Sobre o acumulo de temperatura após abertura dos silos. Ranjit \& Kung (2000) mencionam que a adição de cepas de LAB (L. plantarum) na forragem a ser ensilada pode melhorar o processo de fermentação pela maior produção de ácido lático e rápida redução do pH. Entretanto, Muck \& Kung (1997), citam que em menos de 30\% dos trabalhos publicados entre 1990 a 1995, a inoculação bacteriana melhorou a estabilidade aeróbica, e no restante não houve efeito significativo ou mesmo, piorou a estabilidade aeróbica. Filya et al (2000), concordando com os dados do presente experimento, não encontrou melhoria na estabilidade aeróbica com a adição de inoculante bacteriano. 
Entretanto, Ranjit \& Kung (2000), trabalhando com silagem de milho, avaliando a estabilidade aeróbica como o tempo gasto para a temperatura da silagem se elevar em $2^{0} \mathrm{C}$ em relação a variação da temperatura ambiente, verificaram a melhoria na estabilidade aeróbica em silagens inoculadas com LAB em relação a silagem controle.

$\mathrm{Na}$ Tabela 4 (corte de verão), foi verificado que o tratamento $\mathrm{MO}$ com a PMe, obteve a menor temperatura acumulada significativa $(P<0,05)$, em relação a todos os demais tratamentos. Esse resultado refletiu na interação tripla significativa $(P<0,05)$ entre MS $\times$ PART $\times$ EST, pois no corte de inverno não houve diferença significativa entre os doze tratamentos impostos (Tabela 6). As silagens originada do tratamento com a forragem contendo umidade original (MO), partícula picada no menor tamanho (PMe), apresentaram $\mathrm{pH}$ de estabilidade superior $(\mathrm{P}<0,05)$ aos demais tratamentos, com exceção do tratamento PE, PMa e S (INOC), o que suporta a hipótese da concentração superior de ácido ácetico, o que explicaria a melhor estabilidade aeróbica desse tratamento. Nesse sentido, Muck \& Kung (1997), discutem que a estabilidade é afetada pelo $\mathrm{pH}$ e pelas concentrações de ácidos na silagem, sendo que o ácido lático, predominante em silagem de boa fermentação, é menos inibitório que o ácido acético æ̀ leveduras e bolores, causadores de aquecimentos e de perdas, conforme verificado também por Kung \& Ranjit (2000) e Weinberg \& Muck (1996).

Contudo a explicação mais razoável para as menores temperaturas acumuladas no tratamento $\mathrm{MO}$ sob condição de partículas menores (PMe), na silagem produzida no verão, seria justificada pela maior produção de gases (Tabela 9) e maior consumo de açúcares (CNF) (Tabela 2), durante a fermentação. Com a exaustão de substrato para respiração após a abertura, haveria limitação para acréscimos na temperatura. 


\subsubsection{Poder tampão}

Os valores encontrados para o poder tampão na forragem e na silagem estão apresentados nas Tabelas 3 e 4. Os números obtidos concordam com valores apresentado por Coan et al. (2001), que colhendo capim Tanzânia com 45 dias de crescimento vegetativo, encontrou poder tampão de 14,5 mequiv. $100 \mathrm{~g}_{\text {de }} \mathrm{MS}^{-1}$. Cussen et al. (1995), trabalhando com azevém também obteve valores próximos, com o poder tampão na forragem de 21,1 (mequiv.100 $\mathrm{g} \mathrm{MS}^{-1}$ ). Entretanto, Bergamaschine et al. (2000), colhendo capim Tanzânia com 60 dias de crescimento vegetativo, obteve valor mais elevado do poder tampão, 48,6 mequiv. $100 \mathrm{~g}^{-1}$ de MS. Zierenberg et al. (2001), também encontrou o poder tampão em capim Tanzânia superior ao encontrado no presente experimento (60 mequiv. $100 \mathrm{~g} \mathrm{MS}^{-1}$ ).

Observou-se um maior poder tampão nas forragens oriundas do corte de inverno que daqueles do verão (Figura 11). No tratamento MOPC, houve acréscimo no poder tampão com a inclusão do aditivo $\mathrm{PCP}$, sendo mais evidente no corte de verão, devido a maior porcentagem de inclusão (15\% em relação a forragem fresca, contra 5\% no inverno). Evangelista et al. (2001) também observaram esse efeito ao adicionar níveis crescentes de PCP $(0,5$ e $10 \%)$. Isso é provocado pela maior capacidade tamponante da polpa cítrica, devido a concentração relativamente elevada de cálcio na sua composição, originado do processamento industrial da polpa de cítrus.

O pré-emurchecimento da forragem (PE), determinou redução no poder tampão da forragem do presente experimento. Resultados similares foram verificados Playne \& McDonald (1966), justificados pela redução na concentração dos ácidos orgânicos durante o processo de emurchecimento. Entretanto, Tosi et al. (1999), com capim Elefante, obtiveram valores de 23,2

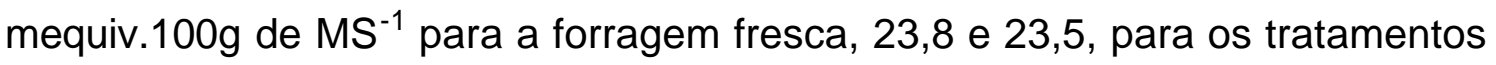
com forragens pré-emurchecidas durante 12 e 24 horas respectivamente, mostrando que o emurchecimento não provocou alteração no poder tampão. 
Concordando, Narciso Sobrinho (1998), avaliando capim Elefante, concluiu que houve aumento no poder tampão (PT) no tratamento pré-emurchecido (24 horas) em relação ao controle, 18,3 e 17,1 mequiv. $100 \mathrm{~g} \mathrm{MS}^{-1}$, respectivamente. Da mesma forma, Vilela et al. (2001) não encontraram diferenças entre a forragem de capim Elefante contendo umidade original (29,9mequiv.100 $\mathrm{g} \mathrm{MS}^{-1}$ ), e a forragem pré-emurchecida durante 6 horas $(30,0)$, e 12 horas $(29,1)$. Esses resultados levam a hipótese, que durante o emurchecimento do capim Elefante até 24 horas, houve a continuidade do metabolismo fisiológico e bioquímico, de forma que a concentração de ácidos orgânicos se manteve elevada, bem como o poder tampão. 


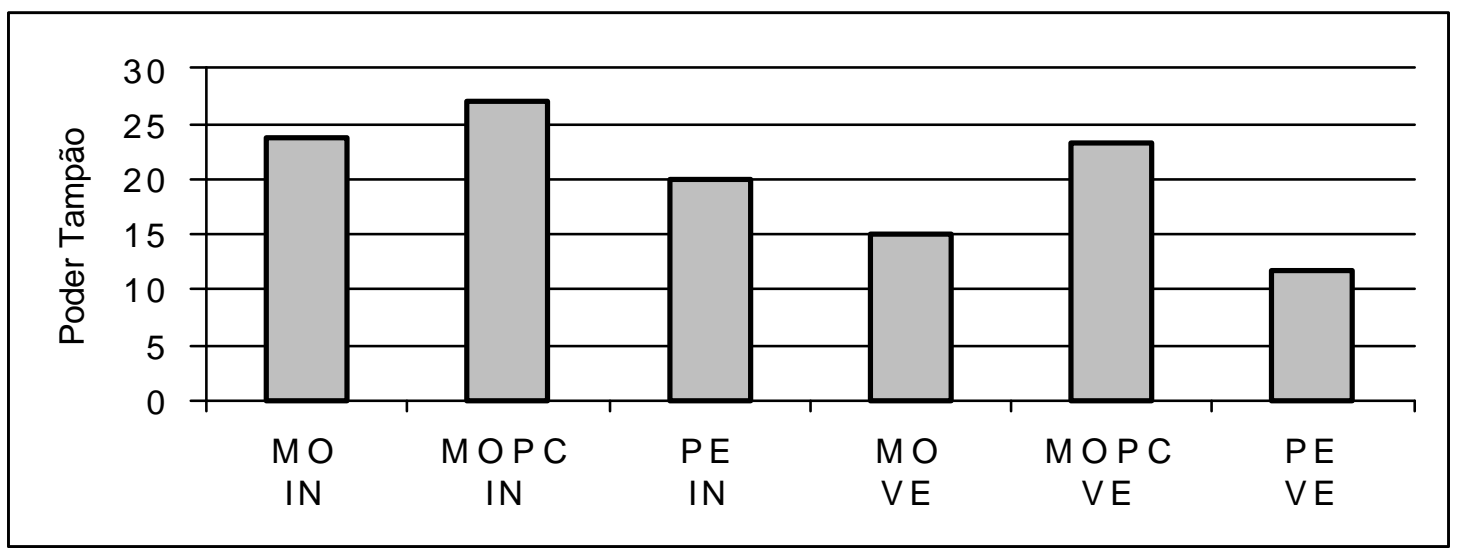

Figura 11 - Valores de poder tampão (mequiv.100g MS ${ }^{-1}$ ), na forragem com umidade original (MO), com polpa cítrica peletizada (MOPC) e pré-emurchecida (PE), nos cortes de inverno (IN) e de verão (VE).

\subsection{9 $\mathrm{pH}$ de estabilidade}

Segundo Vilela (1998), o pH juntamente com a concentração de ácidos orgânicos e nitrogênio amoniacal (\% do nitrogênio total), são parâmetros normalmente empregados na qualificação do processo de ensilagem. Valores de $\mathrm{pH}$ entre 3,8 e 4,2, são esperados para uma silagem bem conservada. No entanto o pH não deve ser empregado como critério exclusivo na avaliação da fermentação, pois seu efeito inibidor é dependente da velocidade de declínio da concentração iônica e do teor de umidade do material ensilado. Assim, McDonald et al., (1991), Vilela (1998) e Zierenberg et al, (2001), mencionam que mais importante que o $\mathrm{pH}$ de estabilidade, é a velocidade com que se declina, a fim de evitar as fermentações indesejáveis.

Nas médias de $\mathrm{pH}$ de estabilidade apresentadas nas Tabelas 3 e 4, houve efeito significativo $(\mathrm{P}<0,01)$ da estação do ano $(\mathrm{EST})$, sendo que para o corte de inverno, obteve-se menores valores $\mathrm{pH}$ em relação ao corte processado no verão. Esse fato deve-se ao teor de matéria seca original da forragem, que no inverno foi superior em relação ao verão $(33,43 \% \mathrm{MS}$ e 
$21,60 \%$ MS, respectivamente), valor próximo do ideal para uma fermentação mais eficiente, segundo Jackson \& Forbes (1970), Silveira et al. (1980), McDonald et al. (1991), Andrade e Lavezzo (1998) e Snijders \& Wouters (1999). Outro fator que provavelmente ocasionou o menor $\mathrm{pH}$ nas silagens no corte de inverno, foram as características climáticas no período, que possibilitaram a planta, através de seus mecanismos fisiológicos, concentrar uma maior proporção de carboidratos solúveis, fato que está de acordo com Buxton \& Fales (1994) e Wilson (1982).

A alteração no teor de matéria seca (TMS) também promoveu efeito significativo $(P<0,05)$, sendo que o tratamento MOPC apresentou $\mathrm{pH}=3,97$, significativamente superior aos tratamentos $\mathrm{MO}(\mathrm{pH}=4,71)$ e $\mathrm{PE}(\mathrm{pH}=4,67)$, os quais não diferiram estatísticamente $(P>0,05)$. $O$ efeito da inclusão de PCP é largamente discutido na literatura, por suas propriedades absorventes e fornecedora de carboidratos solúveis, conforme citado por Evangelista (1996a), Peres (1997), Vilela (1998), Morais (1999), e Muhlbach (1999). Concordando, Aguiar et al. (2001), também obtiveram redução no valor do pH na silagem com a inclusão de doses crescentes de $\operatorname{PCP}(0,5$ e 10\%), atingindo $\mathrm{pH}$ de estabilidade de 5,61, 4,92 e 4,91, respectivamente. Nesse mesmo contexto, Evangelista et al. (2001) também observaram resultados similares, com adição de polpa cítrica para elevar o teor de MS e promover a redução do $\mathrm{pH}$ de silagens de Coast-cross, colhidos com 9 semanas de rebrota. Pedreira et al. (2001), trabalhando com silagem de Tifton 85 (Cynodon ssp), concluíram que a adição de PCP promoveu aumento no teor de matéria seca e dos carboidratos solúveis no material, sendo que a adição de $5 \%$ de PCP diminuiu o pH de 5,2 para 4,9, em comparação com o tratamento controle, possibilitando uma melhor conservação da silagem.

A similaridade estatística $(\mathrm{P}>0,05)$ entre os valores de $\mathrm{pH}$ dos tratamentos $\mathrm{MO}$ e $\mathrm{PE}$, é contraria a expectativa, visto que os teores médios de matéria seca diferiram em seis unidades percentuais $(23,0$ e $29,6 \%$, respectivamente). O poder tampão do tratamento $M O$ foi 3,6 unidades 
percentuais superior ao tratamento PE (19,5 e 15,9 mequiv. $100 \mathrm{~g} \mathrm{MS}^{-1}$, respectivamente), contudo esse fato não aparenta ter proporcionado efeito no $\mathrm{pH}$ de estabilidade, sugerindo que a concentração de carboidratos solúveis foi a característica limitante para o abaixamento do $\mathrm{pH}$ nesses dois tratamentos.

O período de exposição ao emurchecimento foi relativamente curto, em torno de 6 horas, com objetivo de serem evitadas maiores perdas com a reabsorção de água no período noturno. Dessa forma, o tratamento PE ocorrido no verão, elevou a matéria seca da forragem de 16,3\% (MO) para 21,6\% (PE), ficando abaixo do valor previsto (em torno de $28 \%$ de MS). Esse fato foi caracterizado pelas condições climáticas típicas da região onde foi realizado o experimento, quando no dia da ensilagem, constatourse elevada umidade relativa do ar, seguida de intensa nebulosidade. No corte de inverno, a umidade relativa do ar apresentou-se relativamente baixa, com o dia ensolarado e com altas temperaturas, componentes importantes na desidratação das forragens, segundo Moser (1995) e Reis \& Rodrigues (1998), proporcionando a elevação do teor de matéria seca de $29,7 \%$ do MO para $37,7 \%$ no PE.

Assim, no corte de verão, o pH de estabilidade abaixou de 5,25 no $\mathrm{MO}$ (16,34\% MS), para 5,15 no PE $(21,56 \% \mathrm{MS})$, entretanto no corte de inverno esse fato não ocorreu, não apresentando diferença significativa do $\mathrm{pH}$ do tratamento $\mathrm{MO}(\mathrm{pH}=4,18$, com $29,7 \% \mathrm{MS})$, para o $\mathrm{PE}(\mathrm{pH}=4,19$, com $37,7 \%$ MS). Nesse caso, a não alteração do pH talvez seja explicada pela variações no poder tampão. No tratamento $\mathrm{PE}$, especialmente no verão, os valores de poder tampão foram significativamente menores, permitindo abaixamento do $\mathrm{pH}$. Portanto no verão, a variação relativa do teor de matéria seca que passou de $16,3 \%$ para $21,6 \%$, possibilitou a maior capacidade fermentativa, ao passo que no corte de inverno o teor de matéria seca do tratamento $\mathrm{MO}$, já havia atingido o limiar. recomendado, 29,7\%, fato que permitiu a ocorrência de fermentação satisfatória, resultando em $\mathrm{pH}$ de 4,18.

Os valores de $\mathrm{pH}$ verificados na literatura para gramíneas préemurchecidas, são similares aos obtidos no presente experimento, entretanto o 
tempo de emurchecimento geralmente é maior que 6 horas. Aguiar et al. (2001), emurchecendo capim Tanzânia por 12 horas, reduziu o pH de 5,61 (19,99\% MS) para 5,55 (31,18\% MS). Berto \& Mulhbach (1997), com 26 horas de emurchecimento de aveia preta, elevou o teor de MS de 18,7 para 35,8\%, provocando o abaixamento do $\mathrm{pH}$ de 4,6 para 4,2. Vilela et al. (2001), analisando silagem de capim Elefante emurchecido, observaram efeito quadrático na análise do $\mathrm{pH}$, sendo que no tempo zero (17,5\% MS) obtiveram $\mathrm{pH}$ de 3,8 ; com 6 horas de emurchecimento (25,6\% MS) pH de 3,0, e com 12 horas $(31,2 \% \mathrm{MS}), \mathrm{pH}$ de 3,9 . Discordando dos demais autores, Narciso Sobrinho (1998) emurchecendo capim Elefante por 24 horas, elevou o pH de $3,44(19,16 \%$ MS) para 3,61 (27,10\% MS). Contudo, nesses dois últimos trabalhos citados, $\mathrm{o} \mathrm{pH}$ encontrourse dentro da amplitude de silagens com fermentações consideradas satisfatórias.

No tratamento MO ocorreu discordância dos valores de $\mathrm{pH}$ citados na literatura. Quando o teor de matéria seca na forragem apresentou valores inferiores a 20\%, Aguiar et al. (2001) obtiveram pH de 5,61 com Tanzânia, ao passo que experimentos com capim Elefante, Narciso Sobrinho (1998), Muhlbach (1999), Tosi et al. (1999) e Vilela et al. (2001), verificaram valores de $\mathrm{pH}$ entre 3,4 e 4,4, dentro da amplitude recomendada pela literatura. Com teores de matéria seca próximos a 30\%, Castro et al. (2001) observaram pH de 5,36 (25\% de MS) em Cynodon ssp, e Coan et al. (2001) verificaram pH de 4,8 em silagem de Tanzânia tanto com $28,4 \%$, quanto com $31,3 \%$ MS, mostrando valores mais elevados do que os obtidos no presente experimento. 


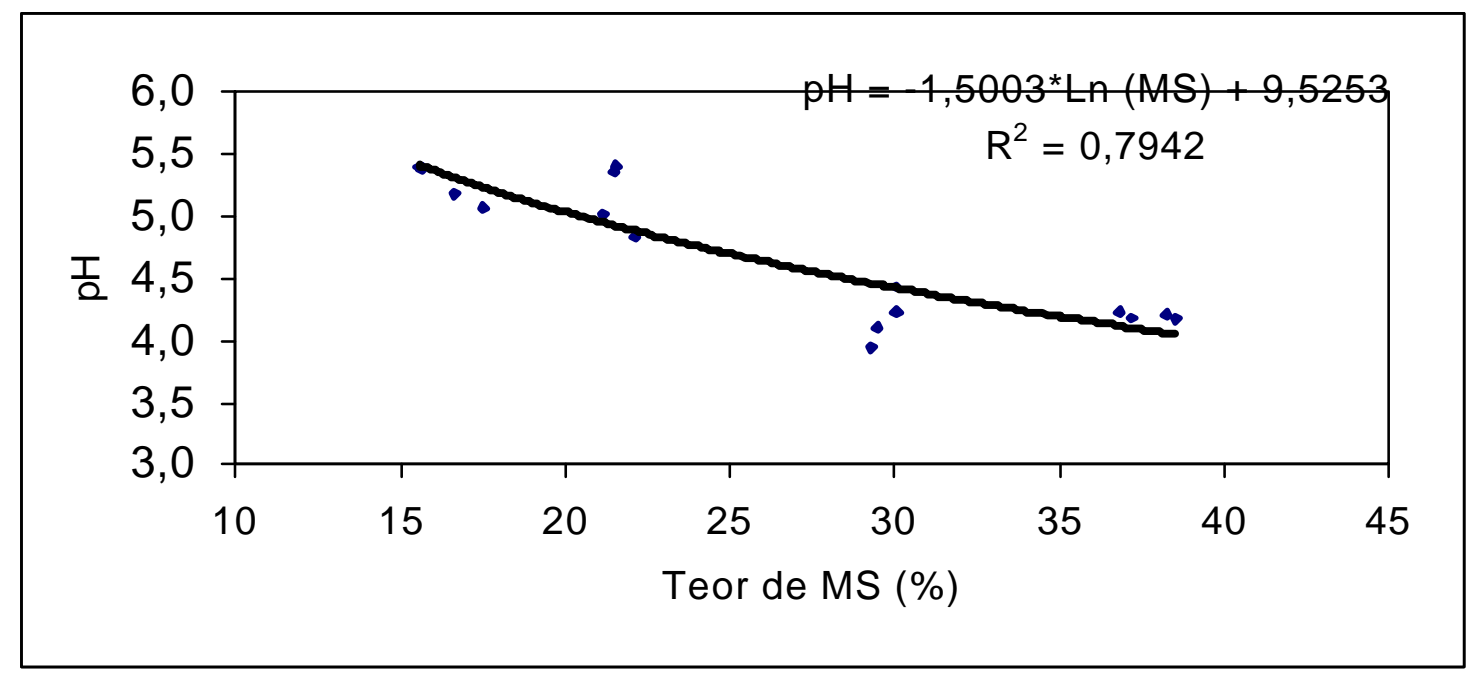

Figura 12 - Efeito do teor de matéria seca no pH de silagens, originadas de forragem contendo umidade original (MO) e pré-emurchecida (PE), no verão e no inverno.

O processo de fermentação e conservação na ensilagem, dependem do teor de matéria seca do material ensilado, do poder tampão, e do teor de carboidratos solúveis (Vilela, 1998; McDonald et al., 1991; Balsalobre et al.,2001; Oude Elferink et al., 1999; Zierenberg et al., 2001; Bergamaschine et al., 2000; e Coan et al., 2001). Dessa forma, analisando a Figura 12, verifica-se que a medida que o teor de matéria seca aumentou, ocorreu uma tendência de redução no $\mathrm{pH}$. O pH mais elevado para o tratamento MO e PE no corte de verão, deve-se ao menor teor de matéria seca (MS), visto que o poder tampão desse tratamentos foi inferior em relação aos demais (Tabela 4). Deve resaltar a tendência observada de redução de $\mathrm{pH}$ como progresso no teor de MS, é provavelmente resultante do confundimento com alterações no teor de carboidratos solúveis na planta. De fato, a literatura apresenta de forma bem documentada a tendência inversa, onde o menor $\mathrm{pH}$ de esstabilidade deveria ser atingido quando associado aos menores teores de MS na planta, uma vez mantido constante, o suprimento de açucares para a fermentação (McDonald et al., 1991; Wooford, 1984). 
Com relação ao tratamento MOPC, não houve diferença significativa $(P>0,05)$ entre os cortes de verão e inverno, sendo que tanto no corte de inverno $(\mathrm{pH}=4,00)$, com $32,9 \%$ de MS e $5 \%$ de PCP na forragem fresca, quanto no corte de verão ( $\mathrm{pH}=3,9)$, com $26,9 \%$ de $\mathrm{MS}$ e $15 \%$ de PCP, mesmo apresentando maior poder tampão em relação aos demais tratamentos, a adição de carboidratos solúveis e elevação na matéria seca, proporcionaram condições para atingir o pH de estabilização preconizado pela literatura.

$\mathrm{Na}$ avaliação de tamanho de partícula foi verificado o efeito significativo $(\mathrm{P}<0,05)$ no $\mathrm{pH}$, sendo que os tratamentos originados com a forragem picada com o menor tamanho (PMe) obtiveram valores de $\mathrm{pH}$ inferiores aos tratamentos com a partícula de maior tamanho (PMa), 4,39 e 4,50 respectivamente. Esse efeito pode ser explicado pela melhor compactação decorrente da redução no tamanho de partícula da forragem picada, o que interferiu na densidade da silagem, apresentando valores de 549,4 $\mathrm{kg} \cdot \mathrm{m}^{-3}$ (PMe) e $501,7 \mathrm{~kg} \cdot \mathrm{m}^{-3}$ (PMa). A melhor compactação da silagem permite que a fase aeróbica no processo da fermentação seja reduzida, promovendo que o perfil fermentativo seja adequado para a conservação satisfatória. Resultados similares foram encontrados por Aguiar et al. (2001), também com silagem de capim Tanzânia.

Não houve efeito significativo para o uso de inoculante bacteriano (INOC) $(P>0,05)$. Esse fato pode ser devido a população bacteriana epífitica original ser suficiente na forragem, sendo que a inoculação de cepas exôgenas, não promoveu diferença nas médias do $\mathrm{pH}$ entre os tratamentos com e sem inoculante. A literatura apresenta resultados conflitantes com relação ao pH de estabilidade com a adição de inoculantes bacterianos. Muck \& Kung (1997), realizaram uma revisão dos trabalhos publicados entre 1990 e 1995, e sumarizaram que o inoculante bacteriano, diminuiu o $\mathrm{pH}$ em aproximadamente $60 \%$ dos casos. Berto \& Mulhbach (1997) com silagem de aveia preta, Clavero (2001) com silagem de Penisetum purpureum cv Mot, Filya et al. (2000) com silagem de trigo pré-emurchecida e sem pré-emurchecimento, Keady \& Steen 
(1995) com azevém, e Cai et al. (2001) com alfafa e azevém, encontraram redução no valor do $\mathrm{pH}$ com uso de inoculante bacteriano. Entretanto Grise et al. (2001) trabalhando com milheto, Ranjit \& Kung Jr (2000) com silagem de milho, e Winters et al. (2001), com silagem de azevém, não obtiveram diferença no $\mathrm{pH}$ entre o controle e a silagem inoculada.

$A$ análise estatística constatou interação tripla significativa $(P<0,05)$ entre o TMS x INOC x EST, conforme apresentado na Tabela 11. A interação se deve ao fato de que os tratamentos com e sem (C e S) inoculante bacteriano (INOC), não apresentaram diferenças significativas dentro dos tratamentos MO, MOPC e PE, somente no processado no verão. Esse fato pode ser interpretado, no sentido que a forragem dentro das condições experimentais, na época do corte de verão, apresentava população microbiana epífitica, suficiente para o atendimento do processo fermentativo da ensilagem. Esse diagnóstico é sugerido pelos relatos de Muck (1989), em que discute sobre a ausência de resposta para inoculantes bacterianos, e destacada como principal causa a quantidade de bactérias de ocorrência natural presentes na forragem, ocasionando a antibiose da população inoculada decorrente da competição entre elas.

Com relação ao corte de inverno, não houve diferença significativa $(P>0,05)$ entre o tratamento PE com (C) e sem (S) inoculante (INOC), fato que evidenciou a menor eficiência da cepa inoculada sob teores de matéria seca mais elevados (37,69\% MS), estando de acordo com os relatos de Sharp et al. (1994). Concordando, Berto \& Mulhbach (1997) avaliando a inoculação de L. plantarum, em silagem pré-emurchecida de aveia preta, com o teor de $34,7 \%$ de MS, não verificaram resposta em relação ao pH. Entretanto, Weinberg \& Muck (1996) apresentam trabalhos com a inoculação de L. plantarum, com efeito positivo no processo fermentativo em forragem pré-emurchecida com teor de matéria seca de 35\%, bem como Rammer \& Slottner (2001), que estudaram o efeito do inoculante $E \operatorname{cosi}^{\circledR}{ }^{\circledR}$, o mesmo utilizado no presente experimento, em quatro leguminosas (G. orientalis, M. sativa, T. repens e T. pratense) e uma 
gramínea (L. perene), ensilando as forragens emurchecidas (35-45\% de MS), e obtiveram resposta positiva com o menor $\mathrm{pH}$ nos tratamentos que utilizaram 0 inoculante.

Assim, o comportamento atípico que gerou a interação tripla, foi originada no tratamento $\mathrm{MO}$, no corte de inverno, onde o $\mathrm{pH}$ se apresentou significativamente maior $(P<0,05)$ para o tratamento com inoculante. A ausência de resposta àinoculação é contrastante com a expectativa em se obter melhor valor de $\mathrm{pH}$, visto que o teor de matéria seca esteve próximo do recomendado como ideal $(29,6 \%)$. Entretanto no tratamento MOPC, durante o corte de inverno, o valor de $\mathrm{pH}$ esteve significativamente $(\mathrm{P}<0,05)$ menor, quando $\mathrm{o}$ tratamento recebeu o inoculante. Nesse caso, o teor de matéria seca da forragem de $32,8 \%$, associado ao suprimento de carboidratos solúveis $(5 \%$ de PCP na forragem fresca), talvez tenham propiciado condições mais adequadas para sua atuação, resultando em um menor pH de estabilidade.

Tabela 11. Médias de pH para os efeitos da alteração do teor de matéria seca (TMS), da adição de inoculante bacteriano (INOC) e da estação do ano (EST), em silagens de capim Tanzânia.

\begin{tabular}{llll}
\hline & & \multicolumn{2}{l}{ Estação (EST) } \\
\cline { 3 - 4 } TMS & INOC & $4,27^{\mathrm{CA}}$ & $5,22^{\mathrm{bcB}}$ \\
\hline MO & $\mathrm{C}$ & $4,08^{\mathrm{bA}}$ & $5,29^{\mathrm{cB}}$ \\
MO & $\mathrm{S}$ & $3,91^{\mathrm{aA}}$ & $3,91^{\mathrm{aA}}$ \\
MOPC & $\mathrm{C}$ & $4,1^{\mathrm{bA}}$ & $3,97^{\mathrm{aA}}$ \\
MOPC & $\mathrm{S}$ & $4,21^{\mathrm{bcA}}$ & $5,11^{\mathrm{bB}}$ \\
PE & $\mathrm{C}$ & $4,17^{\mathrm{bcA}}$ & $5,18^{\mathrm{bcB}}$
\end{tabular}

( $\mathrm{MO}$ - forragem ou silagem com a umidade original; MOPC - forragem ou silagem com adição de polpa cítrica peletizada; PE - forragem ou silagem pré-emurchecida; C - com inoculante bacteriano; S -sem inoculante bacteriano; TMS - efeito da alteração no teor de matéria seca; INOC - efeito do inoculante bacteriano).

Letras maiúsculas diferentes na linha, e letras minúsculas diferentes na coluna indicam diferença significativa $(P<0,05)$. 


\subsubsection{Nitrogênio amoniacal ( $\left.\mathrm{N}-\mathrm{NH}_{3} / \mathrm{Ntotal}\right)$}

O teor de nitrogênio amoniacal (NA) em relação ao nitrogênio total é um parâmetro qualitativo da silagem, que caracteriza o perfil fermentativo ocorrido no processo. Menores teores de NA indicam menor intensidade de proteólise ocorrida na ensilagem, sendo característica de um processo de melhor qualidade. McDonald \& Henderson (1981) inserem que a falta de estabilidade na fermentação da silagem resulta na degradação extensiva de aminoácidos em amônia, $\mathrm{CO}_{2}$ e aminas.

Segundo Benacchio (1965), que classificou a silagem quanto ao teor de nitrogênio amoniacal (NA) em relação ao nitrogênio total, essa é considerada como muito boa, quando os valores são inferiores a $10 \%$, adequada quando entre 10 a $15 \%$, aceitável entre 15 a $20 \%$, e insatisfatória quando os valores se situam acima de $20 \%$.

Os teores de NA observados no presente experimento estão apresentados nas Tabelas 3 e 4 . Houve efeito significativo de estação na produção de NA $(P<0,01)$, sendo que no corte de verão, o valor de NA observado foi de $12,5 \%$, enquanto que para o corte de inverno foi de $5,5 \%$, resultantes do menor teor de matéria seca na forragem no verão (21,6 \% MS) em relação ao inverno (33,4 \% MS). A relação entre a presença de umidade e a ocorrência de fermentação indesejável é amplamente observada em vários trabalhos, uma vez que os teores de matéria seca variando em torno de 28 a $34 \%$, minimizam a ação dos clostrídios, desde que os teores de carboidratos solúveis e o poder tampão não sejam limitantes. (Jackson \& Forbes, 1970; McCullough, 1977; Thomas \& Thomas, 1985; McDonald et al, 1991; Andrade \& Lavezzo, 1998; Wright et al., 2000; Balsalobre et al., 2001).

$A$ atividade de água ( $A W$ ), que se constitui em uma medida de disponibilidade de água para o crescimento de microrganismos, mostrou-se diferente para as duas estações avaliadas, sendo as médias absolutas observadas de 0,94 no inverno e 0,98 no verão. Esse fato, confirma a 
constatação de Greenhill (1964), onde bactérias do gênero Clostridium sp foram inibidas quando a atividade de água esteve abaixo de 0,94, como foi verificado para o corte de inverno, justificando os menores teores de nitrogênio amoniacal (NA).

Foi significativa a alteração do teor de matéria seca (TMS), onde a silagem decorrente da forragem com umidade original (MO), atingiu maiores teores de NA (13,3\%), o tratamento pré-emurchecido (PE) obteve valor de NA de $8,2 \%$, enquanto que menor grau de proteólise ocorreu no tratamento onde adicionou-se PCP (MOPC), com NA igual a 5,5\%. Esses valores estão de acordo com os obtidos por Pedreira et al. (2001), que ensilaram Tifton 95, e verificaram que tanto o pré-emurchecimento quanto a adição de $\mathrm{PCP}$, proporcionaram redução na fração nitrogênio amoniacal.

A adoção da técnica de pré-emurchecimento (PE), consistiu na elevação do teor de matéria seca de 23,0 para $29,6 \%$, compatíveis com os valores absolutos de AW de 0,97 e 0,95 respectivamente, resultando em um menor teor de NA no tratamento PE (8,2\%) em comparação com o MO (13,3\%). Esses valores estão de acordo com os observados por Aguiar et al. (2001), em que o emurchecimendo do capim Tanzânia elevou o teor de MS de 20,4\% para $31,0 \%$, e as médias de NA foram reduzidas de 12,3 para $8,6 \%$. Tosi et al. (1999), emurchecendo capim Elefante também observaram a menor concentração de NA, passando de $25,2 \%$ no controle, para $16,2 \%$ no tempo de 12 horas, e 18,54\% para 24 horas de emurchecimento. A mesma tendência foi observada por Berto \& Muhlbach (1997), ensilando aveia preta emurchecida por 26 horas, onde verificou declínio nos valores de NA de 11,8\% para 8,4\% em relação ao controle. Vilela et al. (2001), registraram valores mais elevados de NA, com capim elefante paraíso, sendo que não houve diferença entre o tratamento controle e aquele proveniente de 6 horas de emurchecimento $(27,1$ e 27,0\%, respectivamente), sendo ambos entretanto superiores às 12 horas de emurchecimento onde houve redução do NA para 25,1\%. Narciso Sobrinho (1998), também avaliando capim elefante, não observou diferença do teor de 
NA para o tratamento pré-emurchecido (24 horas) e o controle, para os cortes realizados com 56 dias de crescimento vegetativo (11,11 e 10,56\%, respectivamente), e 70 dias (10,16 e 9,99\%), sendo que com 84 dias de idade fisiológica houve diminuição no teor de NA de 10,5 para 8,5\%, como efeito do emurchecimento da fo rragem por 24 horas.

A redução do teor de nitrogênio amoniacal (NA) nos tratamentos onde a forragem foi pré-emurchecida, é resultante do efeito benéfico causado pela elevação do teor de MS do material ensilado; contudo, deve-se ressaltar que durante 0 emurchecimento, por 6 horas, no presente experimento, provavelmente não houve proteólise extensa na planta. Essa questão é mencionada por McDonald et al. (1991), que discutem sobre a proteólise durante o emurchecimento no campo, verificando que em períodos curtos de exposição ao emurchecimento, não ocorre proteólise na planta, o que é devido a tensão de oxigênio existente no citoplasma, sendo que as proteases permanecem inativas pela uma vez que necessitam de uma meio redutor para serem ativadas.

Nos tratamentos contendo PCP houve menor concentração de NA, havendo possivelmente a ação integrada da PCP na redução da umidade (29,9\% MS), da AW $(0,96)$, e do fornecimento de carboidratos solúveis, que pode ter proporcionado a queda mais acentuada do $\mathrm{pH}$, tornando o ambiente inadequado para o crescimento de bactérias do gênero Clostridium sp. Essa observação está de acordo com os relatos de Aguiar et al. (2001), onde a inclusão de 0, 5, 10\% de PCP no capim Tanzânia, determinou a redução do teor de NA de $12,3 \%$ para $10,9 \%$ e $5,9 \%$, para os tratamentos propostos. Corrêa \& Cordeiro (2000) também obtiveram redução no teor de NA na silagem de capim Tanzânia com a inclusão de PCP.

Quanto ao efeito do tamanho de partículas, foi verificado $(\mathrm{P}<0,05)$ que a partícula de maior tamanho (PMa) apresentou teor de NA (8,61\%), ligeiramente inferior, que a partícula de menor tamanho (PMe), com valor de NA de 9,35\%. Essa observação discorda dos resultados verificados por Aguiar et al. (2001), 
que ao reduzirem o tamanho de partícula, obtiveram um efeito linear na diminuição do NA, ocasionado pela melhor compactação do material e menor temperatura no silo, reduzindo a atividade proteolítica. Contudo no presente experimento, a redução no tamanho de partícula, apesar de alterar a densidade da silagem, sendo de 549,4 $\mathrm{kg} \cdot \mathrm{m}^{-3}$ (PMe) para 501,7 $\mathrm{kg} \cdot \mathrm{m}^{-3}$ (PMa), não determinou efeito direto sobre os teores de NA.

Não houve efeito significativo $(P>0,05)$ decorrente da inclusão de inoculante bacteriano (INOC) no teor de NA. Efeitos erráticos de inoculantes tem sido observados em silagens, com relação as características fermentativas, conforme relatados na literatura (Weinberg \& Muck ,1996; Vilela, 1998). Gordon (1996), menciona que o inoculante bacteriano pode diminuir a concentração de NA; entretanto, Coan et al. (2001) e Bergamaschine et al. (2001), ambos avaliando a ensilagem de capim Tanzânia, não obtiveram diferença na concentração de NA, com a utilização de um inoculante enzimo bacteriano.

Foi constatada interação dupla significativa $(P<0,05)$, entre TMS $\times$ EST. Tal fato foi verificado pelo menor teor de NA observado no tratamento PE em relação ao MOPC, no corte de inverno, entretanto no corte de verão, o teor de NA no tratamento PE foi maior que o MOPC (Tabela 12). Esse fato foi resultou do maior teor de umidade no tratamento $\mathrm{PE}$, originado do corte de verão $(21,6 \%)$, que devido aos fatores climáticos característicos do verão não foi suficiente para elevar o teor de MS a teores próximos de $28 \%$, após 6 horas de secagem. No corte de inverno, o emurchecimento proporcionou menor teor de umidade $(37,69 \% \mathrm{MS})$, o que ocasionou um menor teor de nitrogênio amoniacal (NA). 
Tabela 12. Médias dos teores de nitrogênio amoniacal (NA) em relação nitrogênio total $\left(\mathrm{N}-\mathrm{NH}_{3}\right.$.Ntotal ${ }^{-1}$, \%), para os efeitos da estação do ano (EST) e da alteração no teor de matéria seca (TMS).

\begin{tabular}{|c|c|c|}
\hline \multirow[b]{2}{*}{ TMS } & \multicolumn{2}{|c|}{ ESTAÇÃO } \\
\hline & INVERNO & VERÃO \\
\hline $\mathrm{MO}$ & $6,3^{\mathrm{Aa}}$ & $20,3^{\mathrm{Ba}}$ \\
\hline MOPC & $5,3^{A b}$ & $5,7^{A c}$ \\
\hline PE & $4,9^{\mathrm{Ac}}$ & $11,4^{\mathrm{Bb}}$ \\
\hline \multicolumn{3}{|c|}{$\begin{array}{l}\text { (MO - forragem ou silagem com a umidade original; MOPC - forragem ou silagem com } \\
\text { adição de polpa cítrica peletizada; } \mathrm{PE} \text { - forragem ou silagem pré-emurchecida; TMS - } \\
\text { efeito da alteração no teor de matéria seca) } \\
\text { Letras maiúsculas diferentes na linha, e letras minúsculas diferentes na coluna indicam } \\
\text { diferença significativa }(P<0,05) \text {. }\end{array}$} \\
\hline
\end{tabular}

Também foi verificada interação dupla significativa $(P<0,05)$, entre TMS $x$ PART. A interação foi originada do maior teor de NA observado no tratamento de tamanho de partícula menor (PMe), em relação a partícula maior tamanho (PMa) em silagem contendo a umidade original (MO). Nos tratamentos MOPC e PE, a alteração do tamanho da partícula não determinou diferença significativa no teor relativo de NA (Tabela 12). Esse fato pode ser melhor explorado no sentido que a redução no tamanho de partícula proporcionou um maior extravasamento de conteúdo celular, conforme pode ser constatado pelas médias observadas para condutividade elétrica (CE), apresentadas nas Tabelas 3 e 4 .

O maior extravasamento do conteúdo celular poderia favorecer a atividade de microrganismos proteolíticos como Clostrídios, entretanto as médias absolutas de atividade de água (AW) não sofreram alteração. 
Tabela 13. Médias do teor de nitrogênio amoniacal (NA) em relação nitrogênio total $\left(\mathrm{N}-\mathrm{NH}_{3} \cdot \mathrm{Ntotal}^{-1}\right)$, para os efeitos da alteração do teor de matéria seca (TMS) e do tamanho de partícula (PART).

\begin{tabular}{lcc}
\hline \multirow{2}{*}{ TMS } & \multicolumn{2}{c}{ Partícula (PART) } \\
\cline { 2 - 3 } & Pme & Pma \\
\hline MO & $14,4^{\mathrm{Aa}}$ & $12,1^{\mathrm{Ba}}$ \\
MOPC & $5,6^{\mathrm{Ac}}$ & $5,4^{\mathrm{Ac}}$ \\
PE & $8,1^{\mathrm{Ab}}$ & $8,3^{\mathrm{Bb}}$ \\
\hline
\end{tabular}

(MO - forragem ou silagem com a umidade original; MOPC - forragem ou silagem com adição de polpa cítrica peletizada; PE - forragem ou silagem pré-emurchecida; PMa - partícula maior; PMe - partícula menor; TMS - efeito da alteração do teor de matéria seca; PART - efeito do tamanho de partícula).

Letras maiúsculas diferentes na linha, e letras minúsculas diferentes na coluna indicam diferença significativa $(\mathrm{P}<0,05)$.

\subsubsection{Fração B3}

A fração protéica B3, como é proposta pelo modelo de Cornell, consiste na parcela de proteína insolúvel em detergente neutro (FDN) e solúvel em detergente ácido (FDA), sendo mensurada pela subtração entre as frações nitrogênio ligadas ao FDN e ao FDA.

Sniffen et al. (1992), discutiram em termos nutricionais, que a fração B3 é lentamente degradada no rúmen, visto sua ligação com os componentes da parede celular e que uma alta porcentagem da fração B3 escapa da degradação ruminal. Contudo, a fração B3 tem significativa importância nas reações proteolíticas ocorridas durante a ensilagem, sendo que aumentos na fração de nitrogênio amoniacal (NA), podem ser provenientes da decomposição da fração protéica B3.

As médias da fração B3 referentes aos tratamentos impostos a silagem de capim Tanzânia estão apresentadas nas Tabelas 1 e 2, juntamente com a fração do nitrogênio insolúvel em FDN (N-FDN), e insolúvel em FDA (N-FDA). 
Houve efeito significativo da EST $(\mathrm{P}<0,01)$ no teor da fração $\mathrm{B} 3$, sendo que os valores obtidos na estação de inverno para a fração B3 foram superiores aos observados para os tratamentos da estação de verão, correspondendo a 16,2 e $11,2 \%$ do nitrogênio total, respectivamente. Tendência similar foi observada para o teor de nitrogênio amoniacal (NA), na estação de verão, onde apresentou maior teor de NA (12,5\%) que o da estação de inverno $(5,5 \%$ do nitrogênio total). Assim, sugere-se haver relação inversa entre esses parâmetros (B3 e NA), ainda que não seja dependência funcional direta.

Mesmo reconhecendo que outras frações nitrog6enadas poderiam se comportar como substratos mais disponíveis para a proteólise durante a ensilagem, o desaparecimento da fração B3 e respectivo aumento na fração NA, parecem apresentar correspondência.

A alteração do teor de matéria seca (TMS) também apresentou efeito significativo $(P<0,05)$, havendo aumento no valor da fração B3 para o tratamento pré-emurchecido (PE) (15,8\%), em relação aos tratamentos $\mathrm{MO}$ $(12,21 \%)$ e MOPC $(12,95 \%)$, os quais não diferiram $(P>0,05)$ entre si. Houve maior concentração de NA para o tratamento com maior umidade (MO), apresentando declínio na fração B3. No tratamento PE, as médias para B3 foram, superiores e com isso houve menor acréscimo na fração NA. Entretanto, o tratamento MOPC, diferindo da tendência observada, apresentou mínimos teores de NA, associados a teores intermediários da fação B3. Aguiar et al. (2001), avaliando silagem de Tanzânia, também observaram maior teor da fração B3 no tratamento com o pré-emurchecimento em relação ao tratamento controle.

O tamanho de partícula (PART) apresentou efeito significativo $(\mathrm{P}<0,05)$ sobre a fração B3. O aumento no tamanho das partículas (PMa), avaliado como porcentagem de partículas com diâmetro superior a $1,905 \mathrm{~cm}$, elevou a fração B3 15,1\% em relação a partícula de menor tamanho (PMe), que apresentaram valor de 12,3\%. Essa observação concorda com o teores de NA encontrados, onde a diminuição no tamanho de partícula (PMe) mostrou maior teor de NA em 
relação a partícula maior (PMa). Esse fato é contrário a expectativa, uma vez que a diminuição do tamanho de partícula, que foi determinante de maior densidade, $549 \mathrm{~kg} \cdot \mathrm{m}^{-3}$ (PMe) e $501 \mathrm{~kg} / \mathrm{m}^{-3}$ (PMa), deveria supostamente induzir menor grau de proteólise. Esses dados discordam da observação realizada por Aguiar et al. (2001), onde houve uma tendência linear de aumento da fração B3 e respectiva diminuição do NA, a medida em que houve diminuição no tamanho de partícula.

Houve interação tripla significativa $(P<0,05)$, para TMS $x$ PART $x$ EST. Durante o corte processado no inverno, o tratamento $\mathrm{MO}$ associado à $\mathrm{PMe}$ apresentou maior teor da fração B3 ao similar com PMa, entretanto os tratamentos MOPC e PE, sob a PMa, apresentaram maior valor na fração B3 (Tabela 14). No corte de verão, não houve efeito significativo para o tamanho de partícula, nos tratamentos MO e PE, havendo para o tratamento MOPC, com a partícula maior (PMa), onde foi constatado maior valor na fração protéica B3 (Tabela 15). Contudo, dentro dessas interações, não foi possível encontrar uma explicação biológica para esses acontecimentos.

Tabela 14: Médias da fração protéica B3 (\%, N total), para os efeitos da alteração do teor de matéria seca (TMS) e do tamanho de partícula (PART), na silagem de capim Tanzânia processadas durante o inverno.

\begin{tabular}{lcc}
\hline & \multicolumn{2}{c}{ Partícula (PART) } \\
\cline { 2 - 3 } TMS & Pme & PMa \\
\hline MO & $20,1^{\mathrm{aA}}$ & $13,9^{\mathrm{aB}}$ \\
MOPC & $19,7^{\mathrm{aA}}$ & $20,0^{\mathrm{bB}}$ \\
PE & $11,8^{\mathrm{bA}}$ & $17,6^{\mathrm{bB}}$ \\
\hline
\end{tabular}

( $\mathrm{MO}$ - forragem ou silagem com a umidade original; MOPC - forragem ou silagem com adição de polpa cítrica peletizada; PE - forragem ou silagem préemurchecida; PMa - partícula maior; PMe - partícula menor; TMS - efeito da alteração no teor de matéria seca; PART - efeito do tamanho de partícula) Letras maiúsculas diferentes na linha, e letras minúsculas diferentes na coluna indicam diferença significativa $(P<0,05)$. 
Tabela 15. Médias da fração protéica B3 (\%, N total), para os efeitos da alteração do teor de matéria seca (TMS) e do tamanho de partícula (PART), na silagem de capim Tanzânia processadas durante o verão.

\begin{tabular}{lcc}
\hline & \multicolumn{2}{c}{ Partícula (PART) } \\
\cline { 2 - 3 } TMS & PMe & PMa \\
\hline MO & $6,9^{\mathrm{aA}}$ & $8,0^{\mathrm{aA}}$ \\
MOPC & $6,3^{\mathrm{aA}}$ & $11,8^{\mathrm{bB}}$ \\
PE & $19,3^{\mathrm{bA}}$ & $14,8^{\mathrm{bA}}$ \\
\hline
\end{tabular}

( $\mathrm{MO}$ - forragem ou silagem com a umidade original; MOPC - forragem ou silagem com adição de polpa cítrica peletizada; PE - forragem ou silagem pré-emurchecida; PMa partícula maior; PMe - partícula menor; TMS - efeito da alteração no teor de matéria seca; PART - efeito do tamanho de partícula).

Letras maiúsculas diferentes na linha, e letras minúsculas diferentes na coluna indicam diferença significativa $(P<0,05)$.

4.2.12 Fibra insolúvel em detergente neutro (FDN)

Segundo Van Soest (1994), a fração fibra detergente neutro (FDN), em forragens, é compreendida pelas frações hemicelulose, celulose, Lignina, além de cutina e sílica.

Os valores obtidos para FDN nos tratamentos estão apresentados nas Tabelas 1 e 2 e são relativamente inferiores aos obtidos por vários trabalhos presentes na literatura. Bergamaschine et al. (2001), obtiveram valor de $74,7 \%$ de FDN, em silagens de capim Tanzânia. Coan et al. (2001), encontraram valores de 76,5 e 79,0\% de FDN, para silagens de capim Tanzânia com 45 e 60 dias de crescimento vegetativo, respectivamente. Nussio et al. (2000), realizando uma revisão de dados de amostragens de campo, originados em dois laboratórios de bromatologia, constataram valores de FDN variando entre 74,5 e $86,7 \%$.

Houve efeito de estação (EST, $\mathrm{P}<0,05)$ para o teor de FDN. A silagem proveniente do corte de inverno apresento u menor teor de FDN que o corte de verão (61,5\% e $63,6 \%$, respectivamente). Esse fato pode ser justificado por fatores climáticos, como fotoperíodo, temperatura e água, os quais agem no 
verão como estimuladores do espessamento da parede celular, conforme relatos de Buxton \& Fales (1994). Assim sendo, a maior idade fisiológica (15 dias) do capim colhido no inverno, em comparação com o corte de verão, não mostrou influenciou, aparentemente a porcentagem de FDN.

Houve efeito da alteração do teor de matéria seca (TMS) $(P<0,05)$, uma vez que o teor de FDN do tratamento MOPC (55,4\%), foi inferior aos tratamentos MO $(65,6 \%)$ e PE $(66,2 \%)$. O motivo que justifica a redução no teor de FDN no tratamento MOPC, deve-se a inclusão de PCP, que contém baixo teor de FDN (23\%) (Vilela, 1998). Crestana et al. (2001) verificaram a mesma tendência ao incluírem 5 e 10\% de PCP em silagem de capim Tanzânia, verificando o declínio do teor de FDN de 68,1\% (0\% PCP), para 63,9\% (5\% de PCP) e $60,8 \%$ (10\% de PCP). Esses teores de FDN observados estão próximos aos obtidos no experimento em discussão.

A alteração do tamanho de partícula não mostrou efeito significativo sobre o teor de FDN ( $P>0,05)$, tendo como médias os valores de $62,2 \%$ para a partícula menor (PMe) e 62,3\% para a partícula maior (PMa). Crestana et al. (2001) não verificaram alteração no teor de FDN quando foi alterado o tamanho de partícula em silagens de capim Tanzânia.

Não houve efeito significativo $(P>0,05)$ da adição de inoculante bacteriano (INOC), sendo encontrado valores de FDN de $62,3 \%$ com (C) INOC e $62,5 \%$ sem (S). Esse resultado concorda com Bergamaschine et al. (2001), onde a inclusão de um aditivo bacteriano não alterou o teor de FDN das silagens, verificando-se médias de $75,2 \%$ e $73,7 \%$, com e sem inoculante bacteriano respectivamente. Clavero (2001), avaliando a silagem de capim Elefante, também não verificou diferença significativa $(P>0,05)$ no teor de FDN com a adição de inoculante bacteriano, obtendo valores de 65,3\% no tratamento controle, e de $61,8 \%$ no tratamento contendo LAB.

Foi constatado interação dupla significativa $(P<0,05)$ para TMS $\times$ EST para o teor de FDN da silagem. Isso foi devido à diminuição do FDN no tratamento MOPC, durante o corte de inverno em relação ao verão. Nos 
tratamentos $\mathrm{MO}$ e $\mathrm{PE}$, ocorreu aumento no teor de FDN, do inverno para o verão (Tabela 16). Essa observação é resposta a maior dose de inclusão de PCP, no corte de verão (15\% de PCP), em decorr6encia da maior umidade da forragem de verão em comparação ao corte de inverno, quando adição foi somente de $5 \%$ de PCP.

Tabela 16. Médias da porcentagem de FDN (\%, MS) para os efeitos da estação do ano (EST) e da alteração do teor de matéria seca (TMS), na silagem de capim Tanzânia.

\begin{tabular}{lcc}
\hline & \multicolumn{2}{c}{ ESTAÇÃO } \\
\cline { 2 - 3 } TMS & INVERNO & VERÃO \\
\hline MO & $63,5^{\mathrm{Aa}}$ & $67,7^{\mathrm{Ba}}$ \\
MOPC & $58,1^{\mathrm{Ab}}$ & $52,6^{\mathrm{Bb}}$ \\
PE & $62,8^{\mathrm{Aa}}$ & $69,5^{\mathrm{Ba}}$ \\
\hline
\end{tabular}

(MO - forragem ou silagem com a umidade original; MOPC - forragem ou silagem com adição de polpa cítrica peletizada; PE - forragem ou silagem pré-emurchecida; TMS - efeito da alteração do teor de matéria seca)

Letras maiúsculas diferentes na linha, e letras minúsculas diferentes na coluna indicam diferença significativa $(P<0,05)$.

4.2.13 Fibra insolúvel em detergente ácido (FDA)

A fração fibra detergente ácida (FDA) em forragens, é compreendida principalmente pelas frações celulose e lignina (Van Soest,1994).

Os valores médios de FDA os tratamentos estão apresentados nas Tabelas 1 e 2 . Seguindo a mesma tendência observada para os valores de FDN, essas médias são relativamente inferiores aqueles citadas na literatura. Bergamaschine et al. (2001), apresentaram valor de 50,7\% de FDA em silagens de capim Tanzânia. Coan et al. (2001), encontraram valores de 45,6 e 49,5\% para FDA, em silagens de capim Tanzânia, com 45 e 60 dias de crescimento vegetativo, respectivamente. Nussio et al. (2000), verificaram valores de FDA de silagens de Capim Tanzânia, variando entre 41,8\% e 67,9\%. 
Houve efeito de estação $(E S T)(P<0,05)$ sobre os teores de FDA, onde a silagem proveniente no corte ocorrido no inverno apresentou menor teor de FDA que a do corte de verão (38,1\% e $41,4 \%$, respectivamente). Também houve efeito da alteração no teor de matéria seca (TMS) $(P<0,05)$, sendo que o valor médio do teor de FDA no tratamento MOPC (35,0\%), foi inferior aos tratamentos MO $(42,16 \%)$ e PE $(42,13 \%)$. Crestana et al. (2001) verificaram a mesma tendência, com a inclusão de 5 e 10\% de PCP em silagens de capim Tanzânia, reduzindo o teor de FDA de $42,5 \%$ (0\% PCP) para $39,7 \%$ (5\% de PCP) e $39,0 \%$ (10\% de PCP).

Não houve efeito da alteração do tamanho de partícula $(P>0,05)$, sobre os teores de FDA, correspondentes à médias, para as partículas de menor (PMe) e maior (PMa) tamanhos, de 39,8\% e 39,7\% respectivamente. Discordando dos dados do presente experimento, Crestana et al. (2001) observaram a diminuição no teor de FDA ao reduzir o tamanho de partícula em silagens com e sem pré-emurchecimento, enquanto que em silagens contudo a adição de polpa cítrica peletizada, essa tendência não foi constatada.

A adição de inoculante bacteriano também não produziu efeito significativo ( $P>0,05)$, sendo encontrados valores de $39,6 \%$ e $39,9 \%$, nos tratamentos com e sem a adição de inoculante bacteriano (LAB). Esse resultado concorda com as observações de Bergamaschine et al. (2001) e Coan et al. (2001), avaliando silagem de capim Tanzânia, e Clavero (2001) com silagem de capim elefante, nos quais não houve efeito da inoculação bacteriana no teor de FDA das silagens.

A análise estatística revelou a interação dupla significativa $(P<0,05)$, para TMS x EST (Tabela 17). Como foi observado para o teor de FDN, esse efeito pode ser justificado pela maior dose PCP adicionada do corte ocorrido verão (15\%), ocasionando uma diluição no teor de FDA, no tratamento MOPC quando comparado ao inverno. Nos tratamentos $\mathrm{MO}$ e PE, as silagens apresentaram médias superiores de FDA, no corte de verão. 
Tabela 17. Médias da porcentagem de FDA (\%, MS) das silagens, para os efeitos da estação do ano (EST) e da alteração no teor de matéria seca (TMS).

\begin{tabular}{lcc}
\hline & \multicolumn{2}{c}{ ESTAÇÃO } \\
\cline { 2 - 3 } TMS & INVERNO & VERÃO \\
\hline MO & $38,0^{\mathrm{Aa}}$ & $45,8^{\mathrm{Ba}}$ \\
MOPC & $36,7^{\mathrm{Ab}}$ & $33,2^{\mathrm{Bb}}$ \\
PE & $39,2^{\mathrm{Aa}}$ & $45,1^{\mathrm{Ba}}$ \\
\hline
\end{tabular}

(MO - forragem ou silagem com a umidade original; MOPC - forragem ou silagem com adição de polpa cítrica peletizada; PE - forragem ou silagem pré-emurchecida; TMS - efeito da alteração do teor de matéria seca)

Letras maiúsculas diferentes na linha, e letras minúsculas diferentes na coluna indicam diferença significativa $(\mathrm{P}<0,05)$.

\subsubsection{Hemicelulose}

A hemicelulose é compreendida como um carboidrato estrutural formada por uma cadeia principal de xilanas com ligações â $(1-4)$ nas unidades de D xilose, com cadeias laterais de ácido metil glucurônico, e frequentemente glicose, galactose e arabinose (Van Soest, 1994).

Os teores de hemicelulose na forragem e na silagem estão apresentados nas Tabelas 1 e 2, se situando dentro da amplitude de valores sugerida por McDonald et al. (1991), que reportam que a hemicelulose contida nas gramíneas aumenta com a maturidade, apresentando variação de 10 a 30\% na matéria seca.

A análise da estabilidade da fração hemicelulose durante a conservação, no presente experimento, foi realizada através da avaliação da relação entre hemicelulose e FDN, consideradas as variações de outros componentes da planta, principalmente a porção solúvel e o desaparecimento que podem provocar efeitos indiretos na análise exclusiva da fração de hemicelulose.

Os valores obtidos da relação entre hemicelulose e FDN (hemicelulose/FDN) da planta e da silagem, estão apresentados na Tabela 18. O pré-emurchecimento da forragem, tanto no corte processado no inverno 
quanto no verão, promoveu um aumento na relação hemicelulose/FDN. Nas Tabelas 1 e 2 estão apresentados os teores exclusivos de FDN, FDA e hemicelulose na forragem, e verifica-se que o emurchecimento ocasionou a diminuição no teor de FDA, e manutenção dos teores de FDN, indicando um suposto aumento no teor de hemicelulose. Esse fato poderia ser explicado pela provável diminuição da fração celulose da forragem pré-emurchecida, promovida pala indução das celulases da planta. Levitt (1980) menciona que a perda de água determina no aumento da concentração de ácido abcísico, responsável pelo fechamento dos estômatos e elevação na concentração de etileno na planta. O aumento na concentração de etileno induziria a síntese de â - 1,4 endoglucanase (celulase), sendo essa atividade atribuída a síntese de novo. Portanto a desidratação da planta, através do emurchecimento, seria capaz de induzir a síntese de celulases, promovendo a diminuição no teor de celulose da planta pré-emurchecida.

Tabela 18. Médias da relação hemicelulose / FDN na forragem e na silagem de capim Tanzânia, decorrentes dos tratamentos experimentais.

\begin{tabular}{|c|c|c|c|c|c|c|}
\hline \multirow[b]{2}{*}{ TMS } & \multirow[b]{2}{*}{ PART } & \multirow[b]{2}{*}{ INOC } & \multicolumn{2}{|c|}{ INVERNO } & \multicolumn{2}{|c|}{ VERÃO } \\
\hline & & & Forragem & Silagem & Forragem & Silagem \\
\hline $\mathrm{MO}$ & PMe & $C$ & 0,38 & $0,38^{\text {Aab }}$ & 0,33 & $0,33^{\mathrm{Aab}}$ \\
\hline MO & PMe & $S$ & 0,39 & $0,37^{A a b}$ & 0,30 & $0,29^{\mathrm{Ba}}$ \\
\hline MO & PMa & C & 0,35 & $0,40^{A a b}$ & 0,40 & $0,28^{\mathrm{Ba}}$ \\
\hline MO & PMa & $S$ & 0,36 & $0,41^{\mathrm{Aab}}$ & 0,30 & $0,33^{\text {Aab }}$ \\
\hline MOPC & $\mathrm{PMe}$ & C & 0,49 & $0,36^{\mathrm{Aa}}$ & 0,32 & $0,37^{\text {Aab }}$ \\
\hline MOPC & PMe & $S$ & 0,49 & $0,37^{A a b}$ & 0,38 & $0,32^{\mathrm{Aab}}$ \\
\hline MOPC & PMa & C & 0,47 & $0,36^{\mathrm{Aa}}$ & 0,29 & $0,34^{\mathrm{Aab}}$ \\
\hline MOPC & $\mathrm{PMa}$ & $S$ & 0,51 & $0,38^{A a b}$ & 0,37 & $0,35^{\text {Aab }}$ \\
\hline PE & PMe & C & 0,50 & $0,38^{A a b}$ & 0,35 & $0,42^{\mathrm{Ab}}$ \\
\hline PE & PMe & $S$ & 0,47 & $0,35^{\mathrm{Aa}}$ & 0,37 & $0,36^{\text {Aab }}$ \\
\hline PE & $\mathrm{PMa}$ & C & 0,44 & $0,42^{\mathrm{Ab}}$ & 0,40 & $0,36^{A a b}$ \\
\hline PE & PMa & $S$ & 0,41 & $0,37^{\mathrm{Aab}}$ & 0,45 & $0,32^{A a b}$ \\
\hline
\end{tabular}

( $\overline{\mathrm{MO}}$ - forragem ou silagem com a umidade original; MOPC - forragem ou silagem com adiçã̃o de polpa cítrica peletizada; PE - forragem ou silagem pré-emurchecida; PMa - partícula maior; PMe - partícula menor; C - com inoculante bacteriano; S -sem inoculante bacteriano; TMS efeito da alteração no teor de matéria seca; PART - efeito do tamanho de partícula; INOC efeito do inoculante bacteriano).

Letras maiúsculas diferentes na linha, e letras minúsculas diferentes na coluna indicam diferença significativa $(P<0,05)$. 
A análise estatística mostrou efeito significativo $(P<0,05)$ de estação (EST) para a relação hemicelulose/FDN, mostrando que a silagem colhioda no inverno apresentou valores superiores aos da silagem de verão, com médias de 0,38 e 0,34 , respectivamente. Isso é devido as características originais da forragem, visto que a forragem de inverno apresentou valor médio de 0,44, superior ao da forragem de verão, a qual apresentou a relação com valor de 0,36 . Não houve efeito significativo $(P>0,05)$ para a alteração do teor de matéria seca (TMS), variação do tamanho de partícula (PART), e presença do inoculante bacteriano (INOC).

A similaridade estatística $(P>0,05)$ entre a silagem pré-emurchecida $(P E)$ e a silagem contendo a forragem com a umidade original $(\mathrm{MO})$, revela que ocorreu maior desaparecimento de hemicelulose, no processo fermentativo, proveniente dos tratamentos submetidos ao emurchecimento, uma vez que a forragem original pré-emurchecida apresentou maior valor da relação hemicelulose/FDN. Assim, supõe-se que por ter havido consumo de carboidratos solúveis durante o emurchecimento, houve necessidade de utilização de carboidratos estruturais, para atender a demanda de substrato para a produção de ácidos na fase de fermentação da silagem. Esse raciocínio é justificado pela similaridade dos valores de $\mathrm{pH}$ encontrados nos tratamentos MO e PE, conforme Tabelas 3 e 4.

McDonald et al. (1991) mencionam que durante o período de ensilagem, a quantidade de ácidos, produzidos é geralmente maior que a disponibilidade correspondente e exclusiva de carboidratos solúveis, sugerindo que substâncias como proteína, aminoácidos, ácidos orgânicos e principalmente carboidratos estruturais, podem ser utilizados pelos microrganismos como substrato. Concordando, Crestana et al. (2001) constataram que a fração hemicelulose contribuiu efetivamente como substrato para a fermentação da silagem de capim Tanzânia. A hidrólise da hemicelulose pode ser realizada por hemicelulases provenientes da planta e das bactérias, e também por ácidos orgânicos produzidos na fermentação (McDonald et al., 1991). 


\subsubsection{Nutrientes Digestíveis Totais (NDT)}

O índice de disponibilidade energética NDT (nutrientes digestíveis totais), aplicado æ̀ forragens e silagens, foi calculado a partir da fórmula proposta por Weiss, citada no NRC (2001).

Os valores de NDT das silagens decorrentes dos respectivos tratamentos estão apresentados nas Tabelas 1 e 2. Esses valores se aproximam aos apresentados por Nussio et al. (2000), que relatam amplitude de variação de entre $34,7 \%$ e $62,2 \%$, com o valor médio de 48,0\%, em 10 amostras de silagens de capim Tanzânia analisadas.

No presente experimento constatourse efeito significativo de estação $(P<0,05)$, nas médias calculadas para o NDT. A média de todos os tratamentos impostos durante o corte de verão resultou em $51,5 \%$ de NDT, inferior ao valor médio obtido para o corte inverno, que foi de 53,0\%. Apesar da silagem de verão apresentar maiores teores protéico (6,3\% contra 6,0\% no inverno) e do extrato etéreo (EE) $(1,7 \%$, contra $1,6 \%$ no inverno), o teor médio de FDN foi

superior no verão $(63,3 \%$ e $61,5 \%$ no inverno), bem como o teor de carboidratos não fibrosos foi superior no inverno (18,7\%, contra $15,8 \%$ no verão). Associa-se a composição bromatológica da silagem as menores perdas de efluente $(5,1 \%$ contra $38,1 \mathrm{~kg} / \mathrm{t}$. MS, no verão), e de gases $(3,0 \%$, e de $5,3 \%$ da MS, mo verão), proporcionando assim, maior densidade energética (NDT) para o corte originado no inverno.

A alteração do teor de matéria seca também promoveu efeito significativo $(P<0,05)$, com média de $52,7 \%$ de NDT para o tratamento MOPC superior aos tratamentos $\mathrm{MO}$ e $\mathrm{PE}$, que foram significativamente semelhantes ( $P>0,05)$, com valores de $50,6 \%$ e $49,1 \%$, respectivamente. O tratamento MOPC apresentou maior densidade energética pelo efeito direto da adição de PCP na silagem, pois além de aumentar o teor de matéria seca da mistura, a PCP elevou o teor 
de NDT ponderado da mistura. Adição de PCP também induziu à menores perdas por efluente, gases e maior recuperação da matéria seca ensilada, além de proporcionar um melhor perfil fermentativo, com abaixamento do $\mathrm{pH}$ e menor teor de nitrogênio amoniacal (NA). Resultados similares foram obtidos por Crestana et al. (2001), que adicionando 5 e 10\% de PCP na ensilagem de capim Tanzânia, observaram o aumento de NDT de 56\% (testemunha), para $57,9 \%$ ( $5 \%$ de PCP) e para $62,8 \%$ (10\% de PCP).

A silagem produzida com a forragem contendo umidade original (MO) apresentou maior teor de nitrogênio amoniacal (NA), maior produção de gás e efluente, que o tratamento utilizando a forragem pré-emurchecida $(\mathrm{PE})$, sendo que $\mathrm{opH}$ de estabilidade foi similar para os dois tratamentos. Assim, no tratamento $\mathrm{MO}$, houve a ocorrência de fermentação segundária e maiores perdas físicas na ensilagem, o que provavelmente poderia justificar o menor teor de NDT observado. Nesse contexto, McDonald et al. (1991) discutem que o destino da fermentação, poderia determinar maiores perdas de matéria seca que as perdas relativas de energia, o que levaria a uma maior concentração energética para a silagem, mesmo com uma menor recuperação de matéria seca. Esse efeito é característico da ação de alguns microrganismos como leveduras, que promovem perdas de $48,9 \%$ de MS e de $0,2 \%$ em energia; de Clostrídium sp, com perdas de $51,1 \%$ em MS e somente $18,4 \%$ em energia; de Enterobactérias, com perdas de $41,1 \%$ em MS e 16,6\% em energia; de bactérias heterofermentativas (glucose), $24 \%$ em MS e 1,7\% em energia; bactérias heterofermentativas (frutose), 4,8\% em MS e 1,0\% em energia; sendo que as bactérias homofermentativas ao produzirem lactato a partir da glucose ou frutose, apresentam perda nula em MS, sendo a perda de energia em $0,7 \%$. Nesse sentido, analisando os dados de recuperação de matéria seca apresentados nas Tabelas 3 e 4, verificou-se que o tratamento MO promoveu a menor porcentagem de recuperação com $93,1 \%$, seguido do tratamento PE com $95,7 \%$ e o tratamento MOPC com 96,5\%. Assim sendo, esses dados levam a hipótese de que a similaridade da concentração energética (NDT) dos 
tratamentos PE e MO, deve-se ao perfil fermentativo ocorrido durante o processo de ensilagem, onde as perdas de MS mais elevadas poderiam mascarar o efeito das perdas de energia. Esse raciocínio poderia explicar o fato do tratamento $\mathrm{MO}$ ter apresentado a concentração de NDT semelhante ao tratamento $\mathrm{PE}$, apesar de ter sido submetido às perdas de MS mais intensas.

Dessa forma, torna-se fortalecida a hipótese de que as perdas na concentração de nutrientes durante o emurchecimento foram mínimas, devido provavelmente ao curto período de emurchecimento. Também foi verificado, pelo cálculo da concentração de carboidratos não fibrosos, proposto no NRC (2001), que não houve diferença entre os tratamentos de MO e PE (12,8 e 13,1\%, respectivamente). Vale ressaltar que esse índice é estimado pela diferença entre os teores de outros nutrientes, podendo estar susceptível à incidência de erros metodológicos acumulados.

Existem vários trabalhos divergentes a respeito do efeito do préemurchecimento em silagens. Lavezzo (1985), citou que o capim elefante emurchecido por 6 horas aumentou o teor de NDT da silagem de 57,4\% (testemunha) para 62,3\%, sendo que em outro experimento, o emurchecimento diminuiu esse teor de 58,2\% (testemunha), para 57,3\%, na silagem emurchecida por 8 horas, e para $53,7 \%$ quando a desidratação se estendeu por 12 horas. Cao et al. (2001) avaliando a ensilagem da alfafa, não verificou declínio do teor de NDT da silagem emurchecida $(66,6 \%)$ para a não emurchecida (65,3\%). Charmley \& Thomas (1987), Dawson et al. (1999), Yan et al. (1998), e Fitzgerald (1996), todos trabalhando com silagem de azevém, não verificaram diferença na densidade energética, resultante do préemurchecimento. Entretanto, Gordon et al. (1999), também avaliando a silagem de azevém, verificaram aumento na energia bruta da silagem devido ao préemurchecimento.

O tamanho de partícula não promoveu efeito significativo $(P>0,05)$ sobre o teor de NDT. Foram verificados valores de NDT de $52,3 \%$ para os tratamentos ensilados com a partícula menor (PMe), e 52,2\% para a partícula 
de maior tamanho (PMa). Essa observação foi mencionada por Fitzgerald (1996), que também não verificou diferença na concentração de energia metabolizável para silagens de azevém, com diferentes tamanhos de partícula.

Adição de inoculante bacteriano também não proporcionou aumento no teor de NDT $(P>0,05)$. Foram obtidos os valores de $52,2 \%$ resultantes da inoculação de $L A B$, e 52,3\% sem LAB. Fraser et al. (2001), também não obteve diferença na adição de L.plantarum na silagem de nabo forragueiro (B. oleracea) em relação a energia metabolizável. Entretanto, Cao et al. (2001), constataram aumento no teor de NDT da silagem de alfafa com a inoculação de bactérias, elevando o teor de 61,3 para 66,1\%.

A análise estatística dos dados revelou a interação tripla significativa entre TMS x PART x EST $(\mathrm{P}<0,05)$, conforme apresentado nas Tabelas 19 e 20. Apenas no tratamento PE durante o corte de verão, foi constada diferença significativa entre os tratamentos originados com a partículas menores (PMe) e as maiores (PMa). Nos demais tratamentos da alteração do teor de matéria seca (TMS), não foi observado efeito do tamanho de partícula na estimativa do valor de NDT. O menor teor de NDT observado para as PMa, em relação as $\mathrm{PMe}$, pode ser explicado pela maior produção de efluente, uma vez que as $\mathrm{PMe}$ produziram 27,28 kg.t $\mathrm{t}^{-1}$ de forragem, enquanto que a produção das PMa foi de $37,30 \mathrm{~kg} \cdot \mathrm{t}^{-1}$ de forragem, o que gerou maior escoamento e perdas de nutrientes, causando efeito direto na diminuição da concentração de nutrientes digestíveis totais (NDT). Esse efeito foi contrário a previsão, uma vez que a menor partícula deveria produzir uma quantidade mais elevada de efluente. Vários estudos demonstraram que o efluente é constituído por componentes nitrogenados, açúcares e minerais, e a sua produção resulta em um somatório de perdas do valor nutritivo do alimento (Pitt, et al., 1987; O' Donnell et al., 1997; Haigh, 1999). Fisher et al. (1981), analisaram a composição do efluente de silagens de gramíneas ensiladas com alta umidade, e constataram que $75 \%$ do efluente é produzido durante os primeiros 5 dias após a ensilagem, e que o teor de MS desse variou de $4,4 \%$ a $8,9 \%$, de carboidratos solúveis de $16,4 \%$ a $26,5 \%$, de 
proteína de $0,72 \%$ a $1,42 \%$, e a matéria mineral de $15,9 \%$ a $18,9 \%$, na MS do efluente.

Tabela 19. Médias do teor de NDT (\%, MS) para os efeitos do tamanho de partícula (PART) e da alteração do teor de matéria seca (TMS), em silagens de capim Tanzânia colhidas no inverno.

\begin{tabular}{lcc}
\hline & \multicolumn{2}{c}{ Partícula (PART) } \\
\cline { 2 - 3 } TMS & PMe & PMa \\
\hline MO & $52,3^{\mathrm{Ab}}$ & $52,7^{\mathrm{Aa}}$ \\
MOPC & $55,8^{\mathrm{Ac}}$ & $55,7^{\mathrm{Ab}}$ \\
PE & $49,9^{\mathrm{Aa}}$ & $51,7^{\mathrm{Aa}}$ \\
\hline
\end{tabular}

(MO - forragem ou silagem com a umidade original; MOPC - forragem ou silagem com adição de polpa cítrica peletizada; PE - forragem ou silagem pré-emurchecida; PMa - partícula maior; PMe - partícula menor; TMS - efeito da alteração no teor de matéria seca; PART - efeito do tamanho de partícula)

Letras maiúsculas diferentes na linha, e letras minúsculas diferentes na coluna indicam diferença significativa $(\mathrm{P}<0,05)$.

Tabela 20. Médias do teor de NDT (\%, MS) para os efeitos do tamanho de partícula (PART) e da alteração do teor de matéria seca (TMS), em silagens de capim Tanzânia colhidas no verão.

\begin{tabular}{lcc}
\hline & \multicolumn{2}{c}{ Partícula (PART) } \\
\cline { 2 - 3 } TMS & PMe & PMa \\
\hline MO & $47,8^{\mathrm{Aa}}$ & $49,6^{\mathrm{Ab}}$ \\
MOPC & $58,3^{\mathrm{Ab}}$ & $58,7^{\mathrm{Ac}}$ \\
PE & $49,7^{\mathrm{Aa}}$ & $45,0^{\mathrm{Ba}}$
\end{tabular}

(MO - forragem ou silagem com a umidade original; MOPC - forragem ou silagem com adição de polpa cítrica peletizada; PE - forragem ou silagem pré-emurchecida; PMa - partícula maior; PMe - partícula menor; TMS - efeito da alteração no teor de matéria seca; PART - efeito do tamanho de partícula)

Letras maiúsculas diferentes na linha, e letras minúsculas diferentes na coluna indicam diferença significativa $(P<0,05)$. 


\subsubsection{Cálculo de custos do NDT}

O objetivo foi de realizar uma estimativa de custos dos tratamentos impostos a ensilagem de capim Tanzânia, integrando sua respectivas eficiências observadas nas etapas de colheita e fermentação da forragem.

No Anexo E estão apresentados os dados relativos à produção, perdas inerentes ao processo de colheita da forragem, recuperação da matéria seca após a fermentação, a estimativa da quantidade de NDT na forragem e na silagem por ha, bem como a taxa de recuperação de NDT, que é obtida pelo quociente entre a quantidade de NDT.ha ${ }^{-1}$ na silagem em relação a disponibilidade de NDT.ha-1 no campo. A Figura 13 ilustra os respectivos tratamentos e suas taxas de recuperação de NDT, verificando a superioridade na taxa de recuperação nas silagens de colheitas processadas durante o inverno em relação aquelas ocorridas no verão. Em geral, a adição de polpa cítrica a forragem (MOPC) elevou a taxa de recuperação, em comparação ao tratamento contendo a forragem com a umidade original (MO). O benefício causado pela adição de polpa cítrica peletizada (MOPC) foi verificado através da redução de perdas na forma de efluente e de gases, assim como a menor ocorrência de fermentações indesejáveis, traduzidas pelo menores valores de $\mathrm{pH}$ e de NA, conforme descrito nas Tabelas 3 e 4 . O melhor perfil fermentativo da silagem contatado no inverno, deveu-se ao maior teor de matéria seca na forragem característica nesse período. 


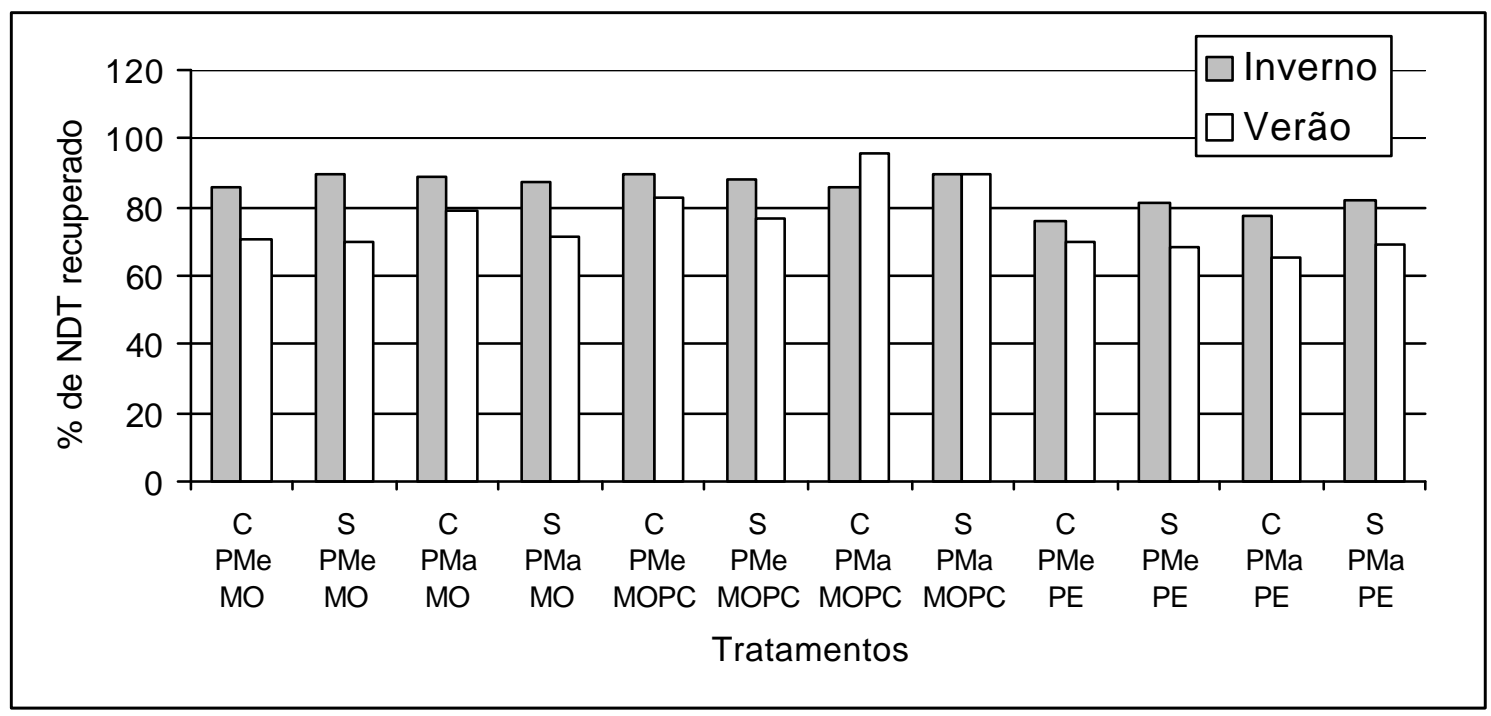

Figura 13 - Porcentagem de NDT recuperado na ensilagem de capim Tanzânia em função dos tratamentos experimentais.

(MO - forragem com a umidade original; MOPC - forragem ou silagem com adição de polpa cítrica peletizada; PE - forragem ou silagem pré-emurchecida; PMa - partícula maior; PMe partícula menor; C - com inoculante bacteriano; S -sem inoculante bacteriano)

O tratamento com o pré-emurchecimento da forragem apresentou as menores taxas de recuperação de NDT, o que foi reflexo da baixa eficiência da operação de recolhimento da forragem emurchecida no campo, onde foram verificados os maiores índices de perdas na colheita, conforme apresentado no Anexo E.

O Anexo $\mathrm{F}$ apresenta os custos adicionais derivados dos tratamentos impostos a silagem, como as adições de PCP, de inoculante bacteriano e a ocorrência de pré-emurchecimento. O cálculo foi realizado com base na tonelada de matéria seca da forragem, em seguida ajustado para o custo por ha, conforme a produtividade de forragem.

A estimativa do custo de produção da silagem por ha, e do custo por kg de NDT da silagem está sumarizada no Anexo G.

Para adequada comparação das médias foi gerado o custo relativo do NDT (\%), no qual foi escolhido o tratamento com menor custo (IN-MO-PMa-S) como a base $100 \%$, e os demais tratamentos estão calculados em relação a 
essa base. Na Figura 14 está ilustrado o custo relativo dos tratamentos, sendo verificado que as silagens produzidas durante o inverno resultaram em menores valores relativos do que aquelas produzidas no verão, seguindo a tendência previamente discutida pela taxa de recuperação de NDT, observado na Figura 13. A maior taxa de recuperação de NDT proporcionou a redução do custo relativo da NDT. Essa tendência foi verificada no tratamento da forragem submetida ao pré-emurchecimento.

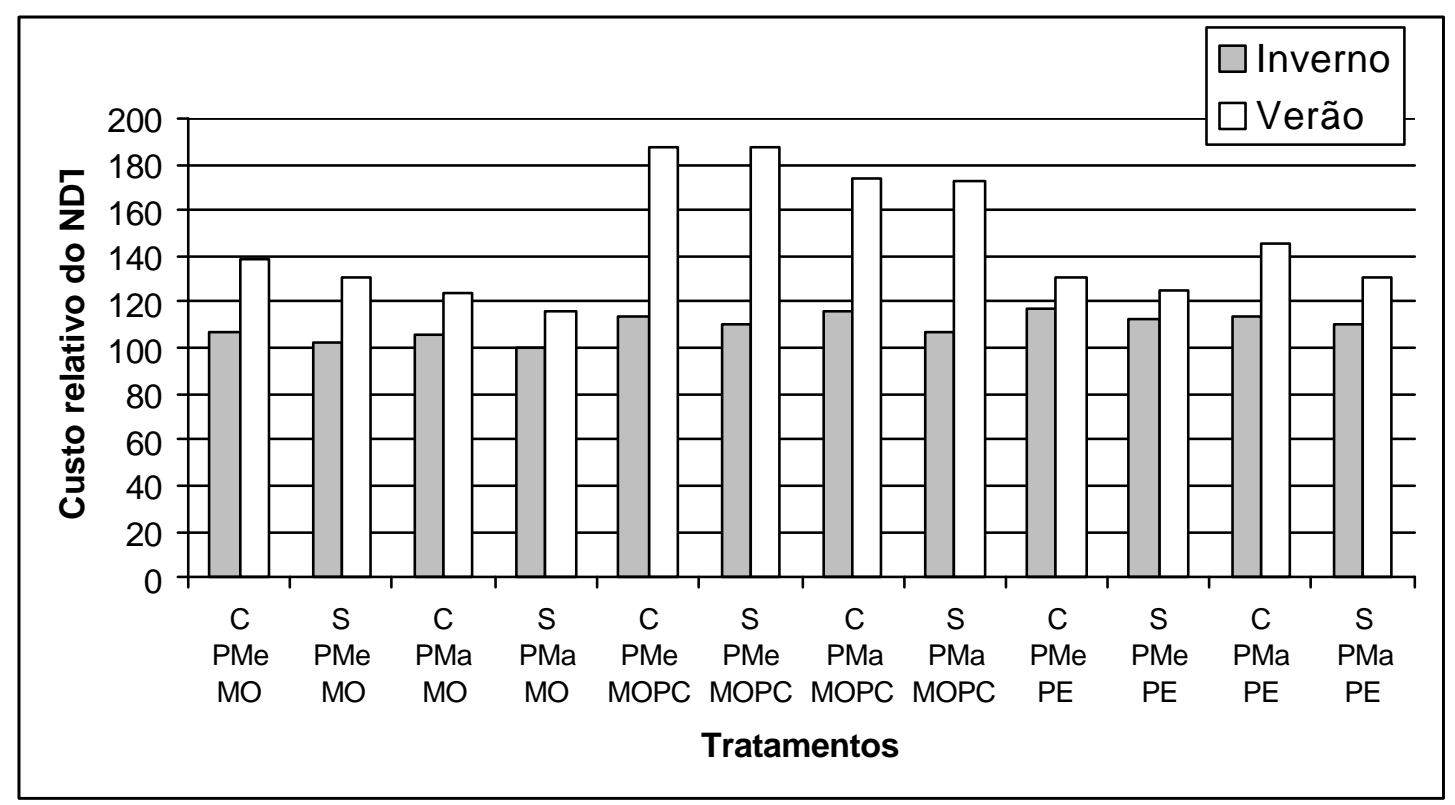

Figura 14 - Custo relativo do NDT (\%) da silagem de capim Tanzânia em função dos tratamentos experimentais.

(MO - forragem com a umidade original; MOPC - forragem ou silagem com adição de polpa cítrica peletizada; PE - forragem ou silagem pré-emurchecida; PMa - partícula maior; PMe partícula menor; C - com inoculante bacteriano; S -sem inoculante bacteriano.)

A adição de $15 \%$ de polpa cítrica peletizada (base da forragem fresca) na silagem produzida no verão, elevou o custo do NDT, como consequência do custo de aquisição adotado para polpa cítrica de $R \$ 130 \cdot \mathrm{t}^{-1}$. Para o corte ocorrido no inverno, o impacto desse custo foi minimizado uma vez que a taxa de adição foi de somente $5 \%$ de PCP. 


\section{CONCLUSÕES}

A colheita e ensilagem de forragem de capim Tanzânia produzida durante o inverno sob condições de manejo intensivo, se constitui numa opção interessante de volumoso suplementar.

As práticas associadas a alteração do teor de matéria seca durante a ensilagem promoveram ganhos em eficiência no processo de fermentação, mais acentuadamente para a forragem colhida no verão. Contudo, a análise de custos revelam a necessidade de julgamento criterioso, para a definitiva recomendação dessas práticas.

A presença de inoculante bacteriano e a redução do tamanho de partícula apenas promoveram benefícios marginais nos parâmetros de eficiência técnica avaliados no processo, havendo questionamento quanto ao benefício econômico de sua adoção.

A análise integrada dos parâmetros avaliados sugerem que o interesse pela silagem de capim Tanzânia, como opção de volumoso suplementar dependem da competência em se reduzir o custo do NDT originado nessa fonte.

A maior eficiência de recolhimento de forragem pré-emurchecida e a redução no tamanho de partícula não acompanhada de aumentos na produção de efluentes, se constitui em áreas promissoras para o desenvolvimento estratégico da indústria de equipamentos associada a colheita de forragens para ensilagem. 
Anexos 
Anexo A. Quadro da análise de variância para as variáveis experimentais.

\begin{tabular}{ll}
\hline Causas de variação & Graus de liberdade \\
\hline Alteração do teor de matéria seca (TMS) & 2 \\
Tamanho da partícula (PART) & 1 \\
Inoculante Bacteriano (INOC) & 1 \\
Interação TMS X PART & 2 \\
Interação TMS X INOC & 2 \\
Interação PART X INOC & 1 \\
Interação TMS X PART X INOC & 2 \\
Resíduo na sub parcela & 36 \\
Estação (EST) & 1 \\
Interação TMS X EST & 2 \\
Interação PART X EST & 1 \\
Interação INOC X EST & 1 \\
Interação TMS X PART X EST & 2 \\
Interação TMS X INOC X EST & 2 \\
Interação PART X INOC X EST & 1 \\
Interação TMS X PART X INOC X EST & 2 \\
Resíduo na parcela & 36 \\
Total & 95 \\
\hline
\end{tabular}


Anexo B. Caracterização das propriedades, do rebanho e das silagens, observadas durante o levantamento de índices técnicos.

\begin{tabular}{|c|c|c|c|c|c|c|c|c|c|}
\hline \multirow[b]{2}{*}{ Propriedade } & \multirow[b]{2}{*}{ UF } & \multirow[b]{2}{*}{ Capim } & \multirow[b]{2}{*}{ Aditivo } & \multicolumn{3}{|c|}{$\mathrm{n}^{0}$} & \multicolumn{3}{|c|}{ Produtividade (ha) } \\
\hline & & & & Atividade & Cabeças & Produção $^{2}$ & tMV.corte $^{-1}$ & tMS.corte & TMS.ano $^{-1}$ \\
\hline Cascata 1 & $\mathrm{SP}$ & Tanzânia & Não & leite & 30 & $8 \mathrm{~L}$ & 20 & 2,7 & 8,1 \\
\hline Oroite & SP & Tobiatã & P.C.P 7\% & leite & 70 & $12 \mathrm{~L}$ & 25 & 4,3 & 12,9 \\
\hline São João & SP & Tanzânia & Não & leite & 100 & $11 \mathrm{~L}$ & 29 & 5,7 & 17,1 \\
\hline Jacutinga & SP & Mombaça & Não & leite & 600 & $20 \mathrm{~L}$ & 21,5 & 7,4 & 22,3 \\
\hline Cascata 2 & SP & Tanzânia & P.C.P. $6 \%$ & corte & 800 & $1,2 \mathrm{~kg}$ & 23 & 3,2 & 9,7 \\
\hline Katayama & SP & Tanzânia & Não & corte & 800 & $1,5 \mathrm{~kg}$ & 35 & 6,4 & 19,1 \\
\hline Negrinha & SP & Tanzânia & Não & corte & 1200 & $1,0 \mathrm{~kg}$ & 14 & 4,9 & 14,7 \\
\hline São José & GO & Tanzânia & Bacteriano & corte & 1400 & $1,0 \mathrm{~kg}$ & 22 & 7,9 & 23,7 \\
\hline Capivara & $\mathrm{SP}$ & Tobiatã & P.C.P 8\% & corte & 1500 & $1,0 \mathrm{~kg}$ & 22 & 3,5 & 10,5 \\
\hline Carpa & MT & Mombaça & Bacteriano & corte & 2000 & $1,4 \mathrm{~kg}$ & 32 & 8,1 & 24,3 \\
\hline São Geraldo & GO & Tanzânia & Bacteriano & corte & 2200 & $1,1 \mathrm{~kg}$ & 20 & 5,2 & 15,5 \\
\hline Rodeio & GO & Mombaça & Bacteriano & corte & 4000 & $1,1 \mathrm{~kg}$ & 14 & 4,5 & 13,5 \\
\hline Santa Fé & GO & Brizantha & Bacteriano & corte & 8000 & $1,1 \mathrm{~kg}$ & 20 & 5,1 & 15,2 \\
\hline Marca & MT & Mombaça & Bacteriano & corte & 40000 & $1,3 \mathrm{~kg}$ & 25 & 7,3 & 21,8 \\
\hline \multicolumn{2}{|l|}{ Média } & & & & 4479 & & 23 & 5,4 & 17,0 \\
\hline \multicolumn{2}{|c|}{ Desvio Padrão } & & & & 10434 & & 6 & 1,8 & 5,3 \\
\hline \multicolumn{2}{|l|}{$C V(\%)$} & & & & 233 & & 25,9 & 32,3 & 32,3 \\
\hline \multicolumn{2}{|c|}{ Valor Maximo } & & & & 40000 & & 35 & 8,1 & 24,3 \\
\hline \multicolumn{2}{|c|}{ Valor Mínimo } & & & & 30 & & 14 & 2,7 & 8,1 \\
\hline
\end{tabular}

Produtividade calculada considerando três cortes anuais.

2 Nível de produção do animal (L.vaca ${ }^{-1} \cdot \mathrm{dia}^{-1}$ ou kg.dia ${ }^{-1}$ ). 
Anexo C. Características fisico-químicas das silagens observadas nas propriedades visitadas durante 0 levantamento de índices técnicos.

\begin{tabular}{|c|c|c|c|c|c|c|c|c|c|c|}
\hline \multirow[b]{2}{*}{ Propriedade } & \multirow[b]{2}{*}{ UF } & \multirow[b]{2}{*}{ Colhedora } & \multirow[b]{2}{*}{$\% \mathrm{MS}$} & \multirow[b]{2}{*}{$\mathrm{pH}$} & \multirow[b]{2}{*}{$\mathrm{CE}^{1}$} & \multicolumn{2}{|c|}{ Densidade } & \multicolumn{3}{|c|}{ Tamanho de Partícula (\%) } \\
\hline & & & & & & $\mathrm{kgMV} \cdot \mathrm{m}^{-3}$ & $\mathrm{kgMS} \cdot \mathrm{m}^{-3}$ & $>1,905$ & $1,91-0,79$ & $<0,78$ \\
\hline Cascata 1 & $\mathrm{SP}$ & ICMA & 13,5 & 4,59 & 828 & 528 & 91,1 & 91,1 & 6,3 & 2,6 \\
\hline Oroite & $\mathrm{SP}$ & Siltomac 730 & 22 & 5,26 & 1076 & 801 & 108,2 & 69,5 & 20,3 & 10,2 \\
\hline São João & SP & Siltomac 775 & 19,6 & 4,97 & 902 & 891 & 174,6 & 88,1 & 7,6 & 4,3 \\
\hline Jacutinga & $\mathrm{SP}$ & Siltomac 706 & 34,5 & 5,09 & 873 & 413 & 142,6 & 91,4 & 5,4 & 3,2 \\
\hline Cascata 2 & $\mathrm{SP}$ & Siltomac 730 & 18,4 & 5,71 & 1120 & 660 & 93,1 & 78,7 & 12,5 & 8,8 \\
\hline Katayama & $\mathrm{SP}$ & Casale 2000 & 18,2 & 5,44 & 910 & 477 & 86,7 & 91,3 & 5,2 & 3,5 \\
\hline Negrinha & $\mathrm{SP}$ & Siltomac 775 & 34,9 & 4,71 & 702 & 484 & 169,0 & 88,7 & 5,3 & 6 \\
\hline São José & GO & Siltomac 730 & 35,9 & 4,27 & 680 & 423 & 152,0 & 85,3 & 5,7 & 9 \\
\hline Capivara & $\mathrm{SP}$ & Siltomac 730 & 21,4 & 4,54 & 786 & 640 & 101,8 & 74 & 17,5 & 8,5 \\
\hline Carpa & MT & Casale 2000S & 25,3 & 5,1 & 1187 & 600 & 151,9 & 82,2 & 10,7 & 7,1 \\
\hline São Geraldo & GO & Siltomac 730 & 25,8 & 4,99 & 997 & 496 & 128,0 & 93,8 & 3,9 & 2,3 \\
\hline Rodeio & GO & Siltomac 730 & 32,2 & 4,05 & 1005 & 540 & 173,9 & 80,9 & 10,1 & 9 \\
\hline Santa Fé & GO & Casale 2000 & 25,4 & 5,13 & 1035 & 723 & 183,5 & 91,3 & 4,4 & 4,4 \\
\hline Marca & MT & Case 7400 & 29 & 4,96 & 1103 & 793 & 230,0 & 12,7 & 71,3 & 15,9 \\
\hline Média & & & 25,4 & 4,92 & 943 & 605 & 141,9 & 79,9 & 13,3 & 6,8 \\
\hline Desvio Padrão & & & 7 & 0,4 & 157 & 151 & 42,5 & 20,6 & 17,4 & 3,8 \\
\hline CV (\%) & & & 27,7 & 9,1 & 16,7 & 25 & 29,9 & 25,8 & 131 & 55,8 \\
\hline Valor Maximo & & & 35,9 & 5,71 & 1187 & 891 & 230,0 & 93,8 & 71,3 & 15,9 \\
\hline Valor Mínimo & & & 13,5 & 4,05 & 680 & 413 & 86,7 & 12,7 & 3,9 & 2,3 \\
\hline
\end{tabular}


Anexo D. Valores de atividade de água (AW) obtidos para forragem.

\begin{tabular}{|c|c|c|c|c|c|c|c|}
\hline Época & TMS & PART & INOC & MS & $\mathrm{m}$ & C & AW \\
\hline IN & $\mathrm{MO}$ & PMe & C & 29,46 & 2,39 & 0,10 & 0,96 \\
\hline IN & $\mathrm{MO}$ & PMe & S & 29,30 & 2,41 & 0,10 & 0,96 \\
\hline IN & $\mathrm{MO}$ & PMa & C & 30,03 & 2,33 & 0,09 & 0,96 \\
\hline IN & $\mathrm{MO}$ & PMa & S & 30,05 & 2,33 & 0,09 & 0,96 \\
\hline \multicolumn{4}{|c|}{ Média } & 29,71 & 2,37 & 0,09 & 0,96 \\
\hline IN & MOPC & PMe & C & 32,53 & 2,07 & 0,12 & 0,94 \\
\hline IN & MOPC & PMe & S & 32,47 & 2,08 & 0,12 & 0,94 \\
\hline IN & MOPC & PMa & C & 33,23 & 2,01 & 0,12 & 0,94 \\
\hline IN & MOPC & PMa & $S$ & 33,30 & 2,00 & 0,12 & 0,94 \\
\hline \multicolumn{4}{|c|}{ Média } & 32,88 & 2,04 & 0,12 & 0,94 \\
\hline IN & PE & PMe & C & 36,83 & 1,72 & 0,12 & 0,93 \\
\hline IN & PE & PMe & $S$ & 37,18 & 1,69 & 0,12 & 0,93 \\
\hline IN & PE & PMa & C & 38,24 & 1,62 & 0,11 & 0,93 \\
\hline IN & PE & PMa & S & 38,54 & 1,60 & 0,11 & 0,93 \\
\hline \multicolumn{3}{|c|}{ Média } & & 37,69 & 1,65 & 0,12 & 0,93 \\
\hline VE & $\mathrm{MO}$ & PMe & C & 15,66 & 5,39 & 0,11 & 0,98 \\
\hline VE & MO & PMe & S & 15,56 & 5,43 & 0,16 & 0,97 \\
\hline VE & $\mathrm{MO}$ & PMa & C & 17,53 & 4,70 & 0,09 & 0,98 \\
\hline VE & $\mathrm{MO}$ & PMa & S & 16,62 & 5,02 & 0,15 & 0,97 \\
\hline \multicolumn{3}{|c|}{ Média } & & 16,34 & 5,13 & 0,13 & 0,98 \\
\hline VE & MOPC & PMe & C & 28,40 & 2,52 & 0,08 & 0,97 \\
\hline VE & MOPC & PMe & S & 27,69 & 2,61 & 0,08 & 0,97 \\
\hline VE & MOPC & PMa & C & 25,67 & 2,90 & 0,09 & 0,97 \\
\hline VE & MOPC & PMa & S & 25,86 & 2,87 & 0,09 & 0,97 \\
\hline \multicolumn{3}{|c|}{ Média } & & 26,90 & 2,72 & 0,08 & 0,97 \\
\hline VE & PE & PMe & C & 22,12 & 3,52 & 0,07 & 0,98 \\
\hline VE & PE & PMe & S & 21,13 & 3,73 & 0,11 & 0,97 \\
\hline VE & PE & PMa & C & 21,52 & 3,65 & 0,07 & 0,98 \\
\hline VE & PE & PMa & S & 21,48 & 3,66 & 0,11 & 0,97 \\
\hline \multicolumn{3}{|c|}{ Média } & & 21,56 & 3,64 & 0,09 & 0,98 \\
\hline
\end{tabular}

(IN - corte de inverno; VE - corte de verão; MO - forragem ou silagem com a umidade original; MOPC - forragem ou silagem com adição de polpa cítrica peletizada; PE - forragem ou silagem pré emurchecida; PMa - partícula maior; PMe - partícula menor; C - com inoculante bacteriano; S - sem inoculante bacteriano; TMS - efeito da alteração no teor de matéria seca; PART - efeito do tamanho de partícula; INOC - efeito do inoculante bacteriano; AW - atividade de água; MS - teor de matéria seca; $m$ - umidade contida (expressa em gramas de água por de gramas de matéria seca; $c$ - constante determinada pelo peso das moléculas e íons da planta), 
Anexo E. Médias dos parâmetros de produtividade da forragem, perdas ocorridas na colheita no campo e na fermentação.

\begin{tabular}{|c|c|c|c|c|c|c|c|c|c|c|c|}
\hline \multicolumn{4}{|c|}{ Tratamentos } & \multirow{2}{*}{$\begin{array}{c}\text { Kg for'. }^{1} \text { (ha) } \\
\text { (ha }\end{array}$} & \multirow{2}{*}{$\begin{array}{c}\% \text { NDT } \\
\text { For }^{1} .\end{array}$} & \multirow{2}{*}{$\begin{array}{c}\text { Perdas } \\
\text { colheita (\%) }\end{array}$} & \multirow{2}{*}{$\begin{array}{l}\% \text { Recup. }^{2} \\
\text { de MS (\%) }\end{array}$} & \multirow{2}{*}{$\begin{array}{l}\text { Kg sil. }^{3} \\
\text { (ha) }\end{array}$} & \multirow{2}{*}{$\begin{array}{l}\% \text { NDT } \\
\text { Sil }^{3} .\end{array}$} & \multirow{2}{*}{$\begin{array}{c}\mathrm{Kg} \text { NDT } \\
\text { (ha) }\end{array}$} & \multirow{2}{*}{$\begin{array}{l}\% \text { NDT } \\
\text { Recup } \\
\end{array}$} \\
\hline Estação & TMS & PART & INOC & & & & & & & & \\
\hline$\overline{\mathrm{IN}}$ & $\mathrm{MO}$ & PMe & $\mathrm{C}$ & 5750 & 56,2 & 4,7 & 96,9 & 5313 & 52,1 & 2769 & 85,7 \\
\hline IN & MO & PMe & $S$ & 5750 & 53,6 & 4,7 & 96,2 & 5274 & 52,4 & 2766 & 89,7 \\
\hline IN & MO & PMa & C & 5750 & 55,0 & 4,7 & 96,6 & 5296 & 52,7 & 2792 & 88,3 \\
\hline IN & MO & PMa & $S$ & 5750 & 56,3 & 4,7 & 98,1 & 5378 & 52,6 & 2829 & 87,5 \\
\hline IN & MOPC & PMe & C & 5750 & 58,1 & 4,7 & 98,4 & 5395 & 55,5 & 2993 & 89,6 \\
\hline IN & MOPC & PMe & $\mathrm{S}$ & 5750 & 59,2 & 4,7 & 97,5 & 5346 & 56,1 & 2998 & 88,0 \\
\hline IN & MOPC & PMa & C & 5750 & 59,4 & 4,7 & 98,5 & 5400 & 54,4 & 2939 & 86,0 \\
\hline IN & MOPC & PMa & $S$ & 5750 & 59,6 & 4,7 & 98,1 & 5378 & 56,9 & 3061 & 89,3 \\
\hline IN & PE & PMe & C & 11470 & 55,5 & 14,1 & 98,4 & 9695 & 49,6 & 4807 & 75,5 \\
\hline IN & PE & PMe & $S$ & 11470 & 51,7 & 14,1 & 97,3 & 9587 & 50,2 & 4809 & 81,1 \\
\hline IN & PE & $\mathrm{PMa}$ & C & 11470 & 55,5 & 14,1 & 96,9 & 9547 & 51,6 & 4927 & 77,4 \\
\hline IN & PE & PMa & $\mathrm{S}$ & 11470 & 52,4 & 14,1 & 96,6 & 9518 & 51,8 & 4933 & 82,0 \\
\hline VE & MO & PMe & C & 8860 & 54,8 & 6,7 & 85,9 & 7101 & 48,0 & 3409 & 70,2 \\
\hline VE & MO & PMe & $S$ & 8860 & 53,0 & 6,7 & 83,4 & 6894 & 47,7 & 3287 & 70,0 \\
\hline VE & MO & PMa & C & 8860 & 53,8 & 6,7 & 91,4 & 7555 & 49,9 & 3771 & 79,1 \\
\hline VE & MO & PMa & $S$ & 8860 & 58,8 & 6,7 & 91,5 & 7564 & 49,2 & 3724 & 71,5 \\
\hline VE & MOPC & PMe & C & 8860 & 60,9 & 6,7 & 91,9 & 7597 & 58,8 & 4468 & 82,8 \\
\hline VE & MOPC & PMe & $S$ & 8860 & 64,3 & 6,7 & 91,0 & 7522 & 57,7 & 4344 & 76,2 \\
\hline VE & MOPC & $\mathrm{PMa}$ & C & 8860 & 57,0 & 6,7 & 98,8 & 8167 & 59,2 & 4837 & 95,8 \\
\hline VE & MOPC & PMa & $S$ & 8860 & 59,2 & 6,7 & 97,6 & 8068 & 58,3 & 4700 & 89,6 \\
\hline VE & PE & PMe & C & 11370 & 52,4 & 22,1 & 93,6 & 8288 & 50,2 & 4160 & 69,8 \\
\hline VE & PE & PMe & $S$ & 11370 & 53,3 & 20,3 & 93,0 & 8423 & 49,1 & 4137 & 68,3 \\
\hline VE & PE & PMa & C & 11370 & 50,9 & 20,3 & 94,5 & 8559 & 44,1 & 3779 & 65,3 \\
\hline VE & PE & PMa & $S$ & 11370 & 50,6 & 20,3 & 95,1 & 8614 & 45,9 & 3954 & 68,7 \\
\hline
\end{tabular}

\footnotetext{
Valores referentes a forragem. ${ }^{2}$ Valores referentes a taxas de recuperação. ${ }^{3}$ Valores referentes a silagem. ${ }^{4} \mathrm{kgNDTsilagem} \mathrm{kga}^{-1} .100 /$ kgNDTfrragem.ha ${ }^{-1}$. (IN - inverno; VE - verão; MO - forragem com a umidade original; MOPC - forragem ou silagem com adição de polpa cítrica peletizada; PE - forragem ou silagem pré emurchecida; PMa - partícula maior; PMe - partícula menor; C - com inoculante bacteriano; $\mathrm{S}$-sem inoculante bacteriano; TMS - efeito da alteração no teor de matéria seca; PART - efeito do tamanho de partícula; INOC - efeito do inoculante 110 bacteriano).
} 
Anexo F. Estimativa dos custos adicionais derivados dos tratamentos impostos àensilagem de capim Tanzânia.

\begin{tabular}{|c|c|c|c|c|c|c|c|c|c|}
\hline \multicolumn{4}{|c|}{ Tratamentos } & \multirow{2}{*}{$\begin{array}{c}\mathrm{PCP}^{\prime} \\
\left(\mathrm{R} \$ . \mathrm{MS}^{-1}\right.\end{array}$} & \multirow{2}{*}{$\begin{array}{c}\mathrm{PCP}^{\prime} \\
\left(\mathrm{R} \$ \cdot \mathrm{ha}^{-1}\right)\end{array}$} & \multirow{2}{*}{$\begin{array}{c}\mathrm{INOC}^{2} \\
\left(\mathrm{R} \$ \mathrm{t} \cdot \mathrm{MS}^{-1}\right)\end{array}$} & \multirow{2}{*}{$\begin{array}{c}\mathrm{INOC}^{2} \\
\left(\mathrm{R} \$ \cdot \mathrm{ha}^{-1}\right)\end{array}$} & \multirow{2}{*}{$\begin{array}{c}\mathrm{PE}^{2} \\
\left(\mathrm{R} \$ \cdot \mathrm{ha}^{-1}\right)\end{array}$} & \multirow{2}{*}{$\begin{array}{c}\text { Total } \\
\left(\mathrm{R} \$ \cdot \mathrm{ha}^{-1}\right)\end{array}$} \\
\hline$\overline{E S T}$ & TMS & PART & INOC & & & & & & \\
\hline IN & $\mathrm{MO}$ & $\mathrm{PMe}$ & C & & & 6,8 & 37,2 & & 37,2 \\
\hline IN & MO & $\mathrm{PMe}$ & $\mathrm{S}$ & & & & & & 0,0 \\
\hline IN & MO & $\mathrm{PMa}$ & C & & & 6,7 & 36,5 & & 36,5 \\
\hline IN & MO & $\mathrm{PMa}$ & $\mathrm{S}$ & & & & & & 0,0 \\
\hline IN & MOPC & $\mathrm{PMe}$ & C & 21,7 & 118,8 & 6,1 & 33,7 & & 152,5 \\
\hline IN & MOPC & PMe & $S$ & 21,7 & 118,8 & & & & 118,8 \\
\hline IN & MOPC & $\mathrm{PMa}$ & C & 21,7 & 118,8 & 6,0 & 33,0 & & 151,8 \\
\hline IN & MOPC & $\mathrm{PMa}$ & $\mathrm{s}$ & 21,7 & 118,8 & & & & 118,8 \\
\hline IN & PE & $\mathrm{PMe}$ & C & & & 5,4 & 53,5 & 20,0 & 73,5 \\
\hline IN & PE & PMe & $S$ & & & & & 20,0 & 20,0 \\
\hline IN & PE & $\mathrm{PMa}$ & C & & & 5,2 & 51,5 & 20,0 & 71,5 \\
\hline IN & PE & $\mathrm{PMa}$ & $S$ & & & & & 20,0 & 20,0 \\
\hline VE & MO & $\mathrm{PMe}$ & C & & & 12,8 & 105,6 & & 105,6 \\
\hline VE & MO & $\mathrm{PMe}$ & $\mathrm{S}$ & & & & & & 0,0 \\
\hline VE & MO & $\mathrm{PMa}$ & C & & & 11,4 & 94,3 & & 94,3 \\
\hline VE & MO & PMa & $S$ & & & & & & 0,0 \\
\hline VE & MOPC & PMe & C & 118,9 & 982,9 & 7,0 & 58,2 & & 1041,1 \\
\hline VE & MOPC & $\mathrm{PMe}$ & $\mathrm{S}$ & 118,9 & 982,9 & & & & 982,9 \\
\hline VE & MOPC & $\mathrm{PMa}$ & C & 118,9 & 982,9 & 7,8 & 64,4 & & 1047,3 \\
\hline VE & MOPC & $\mathrm{PMa}$ & $S$ & 118,9 & 982,9 & & & & 982,9 \\
\hline VE & PE & PMe & C & & & 9,0 & 80,0 & 20,0 & 100,0 \\
\hline VE & PE & $\mathrm{PMe}$ & $S$ & & & & & 20,0 & 20,0 \\
\hline VE & PE & PMa & C & & & 9,3 & 84,2 & 20,0 & 104,2 \\
\hline VE & PE & PMa & $S$ & & & & & 20,0 & 20,0 \\
\hline & & & & & & & $\mathrm{m}$ & Custo & $\begin{array}{l}\text { cional } \\
\text { iddade } \\
\text { em ou } \\
\text { ulante } \\
\text { ART - }\end{array}$ \\
\hline
\end{tabular}


Anexo G. Estimativa de custos do NDT provenientes da silagens de capim Tanzânia, submetidos a alteração do teor de matéria seca, presença de inoculante bacteriano, produzidas no verão ou no inverno.

\begin{tabular}{|c|c|c|c|c|c|c|c|c|c|c|c|}
\hline \multicolumn{4}{|c|}{ Tratamentos } & \multirow{2}{*}{$\begin{array}{c}\text { For. }^{1} \\
(\mathrm{R} \$ \text {.t.MS }\end{array}$} & \multirow{2}{*}{$\begin{array}{c}\text { For. }^{1} \\
\left(\mathrm{R} \$ \mathrm{ha}^{-1}\right)\end{array}$} & \multirow{2}{*}{$\begin{array}{c}\text { Ensil. }^{2} \\
\left(\mathrm{R} \$ . t \mathrm{MS}^{-1}\right.\end{array}$} & \multirow{2}{*}{$\begin{array}{c}\text { Ensil. }^{2} \\
\left(\mathrm{R} \$ \text { ha }^{-1}\right)\end{array}$} & \multirow{2}{*}{$\begin{array}{c}\text { Trat. }^{3} \\
\left(\mathrm{R} \$ . \mathrm{ha}^{-1}\right)\end{array}$} & \multirow{2}{*}{$\begin{array}{c}\text { Total }^{4} \\
\left(\mathrm{R} \$ . \mathrm{ha}^{-1}\right)\end{array}$} & \multirow{2}{*}{$\begin{array}{c}\text { NDT } \\
\left(\mathrm{R} \$ . \mathrm{kg}^{-1}\right)\end{array}$} & \multirow{2}{*}{$\begin{array}{l}\text { Custo rel. } \\
\text { NDT }^{5}(\%)\end{array}$} \\
\hline Estação & TMS & PART & INOC & & & & & & & & \\
\hline IN & MO & PMe & C & 58,8 & 338,2 & 70,7 & 387,7 & 37,2 & 763,2 & 0,28 & 107 \\
\hline IN & MO & $\mathrm{PMe}$ & $\mathrm{S}$ & 58,8 & 338,2 & 70,7 & 387,7 & 0,0 & 725,9 & 0,26 & 102 \\
\hline IN & MO & PMa & C & 58,8 & 338,2 & 70,7 & 387,7 & 36,5 & 762,5 & 0,27 & 106 \\
\hline IN & MO & $\mathrm{PMa}$ & $S$ & 58,8 & 338,2 & 70,7 & 387,7 & 0,0 & 725,9 & 0,26 & 100 \\
\hline IN & MOPC & $\mathrm{PMe}$ & C & 58,8 & 338,2 & 70,7 & 387,7 & 152,5 & 878,4 & 0,29 & 114 \\
\hline IN & MOPC & PMe & $S$ & 58,8 & 338,2 & 70,7 & 387,7 & 118,8 & 844,7 & 0,28 & 110 \\
\hline IN & MOPC & PMa & C & 58,8 & 338,2 & 70,7 & 387,7 & 151,8 & 877,7 & 0,30 & 116 \\
\hline IN & MOPC & $\mathrm{PMa}$ & $\mathrm{S}$ & 58,8 & 338,2 & 70,7 & 387,7 & 118,8 & 844,7 & 0,28 & 108 \\
\hline IN & PE & PMe & C & 58,8 & 674,7 & 70,7 & 696,8 & 73,5 & 1445,0 & 0,30 & 117 \\
\hline IN & PE & PMe & $S$ & 58,8 & 674,7 & 70,7 & 696,8 & 20,0 & 1391,5 & 0,29 & 113 \\
\hline IN & PE & $\mathrm{PMa}$ & C & 58,8 & 674,7 & 70,7 & 696,8 & 71,5 & 1443,0 & 0,29 & 114 \\
\hline IN & PE & $\mathrm{PMa}$ & $\mathrm{S}$ & 58,8 & 674,7 & 70,7 & 696,8 & 20,0 & 1391,5 & 0,28 & 110 \\
\hline VE & MO & PMe & C & 58,8 & 521,1 & 70,7 & 584,6 & 105,6 & 1211,3 & 0,36 & 138 \\
\hline VE & MO & $\mathrm{PMe}$ & $\mathrm{S}$ & 58,8 & 521,1 & 70,7 & 584,6 & 0,0 & 1105,7 & 0,34 & 131 \\
\hline VE & MO & $\mathrm{PMa}$ & C & 58,8 & 521,1 & 70,7 & 584,6 & 94,3 & 1200,1 & 0,32 & 124 \\
\hline VE & MO & $\mathrm{PMa}$ & $S$ & 58,8 & 521,1 & 70,7 & 584,6 & 0,0 & 1105,7 & 0,30 & 116 \\
\hline VE & MOPC & PMe & C & 58,8 & 521,1 & 70,7 & 584,6 & 1041,1 & 2146,9 & 0,48 & 187 \\
\hline VE & MOPC & PMe & $S$ & 58,8 & 521,1 & 70,7 & 584,6 & 982,9 & 2088,6 & 0,48 & 187 \\
\hline VE & MOPC & $\mathrm{PMa}$ & C & 58,8 & 521,1 & 70,7 & 584,6 & 1047,3 & 2153,0 & 0,45 & 173 \\
\hline VE & MOPC & $\mathrm{PMa}$ & $S$ & 58,8 & 521,1 & 70,7 & 584,6 & 982,9 & 2088,6 & 0,44 & 173 \\
\hline VE & PE & PMe & C & 58,8 & 668,8 & 70,7 & 626,2 & 100,0 & 1395,1 & 0,34 & 131 \\
\hline VE & PE & PMe & $S$ & 58,8 & 668,8 & 70,7 & 640,5 & 20,0 & 1329,3 & 0,32 & 125 \\
\hline VE & PE & $\mathrm{PMa}$ & C & 58,8 & 668,8 & 70,7 & 640,5 & 104,2 & 1413,5 & 0,37 & 146 \\
\hline VE & PE & $\mathrm{PMa}$ & $S$ & 58,8 & 668,8 & 70,7 & 640,5 & 20,0 & 1329,3 & 0,34 & 131 \\
\hline
\end{tabular}

TCusto referente a produção da forragem. ${ }^{2}$ Custo referente a processo de ensilagem. ${ }^{3}$ Custos adicionais referentes aos tratamentos. ${ }^{4} \mathrm{Custo}$ total da produção de silagem. ${ }^{5}$ Custo relativo, \% (base o tratamento IN-MO-PMa-S). (IN - inverno; VE - verão; MO - forragem com a umidade original; MOPC -

forragem ou silagem com adição de polpa cítrica peletizada; PE - forragem ou silagem pré emurchecida; PMa-partícula maior; PMe - partícula menor; C - com inoculante bacteriano; S - sem inoculante bacteriano; TMS - efeito da alteração no teor de matéria seca; PART - efeito do tamanho de partícula; INOC - efeito do inoculante bacteriano. 
Anexo H. Valores dos coeficientes de variação (CV, \%) dos parâmetros bromatológicos, da silagem de capim Tanzânia.

\begin{tabular}{|c|c|c|c|c|c|c|c|c|c|c|c|c|c|c|c|c|}
\hline Época & TMS & PART & INOC & $\overline{\mathrm{MS}}$ & PB & $\overline{\mathrm{CFN}}$ & FDN & FDA & Lig. & Hem. & N-FDN & N-FDA & B3 & MM & EE & NDT \\
\hline IN & $\mathrm{MO}$ & $\mathrm{PMe}$ & C & 6,3 & 14,6 & 6,2 & 1,6 & 2,0 & 6,4 & 3,4 & 7,6 & 14,4 & 2,0 & 8,0 & 3,7 & 3,0 \\
\hline IN & MO & PMe & S & 5,0 & 16,5 & 13,3 & 5,8 & 3,3 & 10,5 & 12,1 & 4,4 & 9,7 & 11,7 & 1,4 & 10,6 & 3,5 \\
\hline IN & MO & PMa & C & 2,7 & 4,8 & 17,7 & 2,0 & 6,5 & 10,0 & 13,6 & 11,0 & 14,1 & 10,9 & 9,4 & 8,1 & 3,5 \\
\hline IN & $\mathrm{MO}$ & PMa & $S$ & 1,0 & 7,0 & 11,3 & 5,9 & 8,6 & 11,3 & 12,7 & 17,6 & 12,3 & 11,7 & 3,7 & 11,3 & 3,5 \\
\hline IN & MOPC & PMe & C & 4,1 & 10,8 & 10,4 & 3,3 & 2,4 & 9,3 & 11,6 & 7,2 & 14,5 & 12,7 & 3,7 & 1,3 & 2,0 \\
\hline IN & MOPC & PMe & $S$ & 5,6 & 6,1 & 15,3 & 5,5 & 4,8 & 12,5 & 12,3 & 10,7 & 11,4 & 15,9 & 3,2 & 5,5 & 2,1 \\
\hline IN & MOPC & PMa & C & 1,3 & 4,3 & 15,9 & 4,8 & 4,9 & 11,3 & 9,3 & 13,7 & 8,3 & 10,9 & 6,2 & 1,6 & 5,0 \\
\hline IN & MOPC & PMa & $S$ & 1,9 & 9,1 & 15,3 & 6,7 & 4,1 & 11,9 & 10,7 & 13,1 & 12,4 & 11,2 & 8,0 & 2,3 & 4,2 \\
\hline IN & PE & PMe & C & 3,6 & 8,2 & 10,4 & 1,8 & 3,7 & 10,1 & 9,5 & 6,5 & 11,4 & 14,3 & 3,3 & 7,2 & 1,7 \\
\hline IN & PE & PMe & $S$ & 3,1 & 12,1 & 12,7 & 4,0 & 3,8 & 7,1 & 13,2 & 13,4 & 12,8 & 15,5 & 3,5 & 10,2 & 2,8 \\
\hline IN & PE & PMa & C & 5,6 & 6,5 & 11,3 & 3,4 & 4,7 & 7,7 & 12,4 & 12,4 & 3,1 & 14,7 & 5,1 & 5,1 & 1,3 \\
\hline IN & PE & PMa & $S$ & 4,9 & 7,1 & 18,3 & 4,9 & 3,5 & 6,6 & 16,8 & 5,6 & 10,2 & 5,5 & 9,2 & 1,6 & 3,1 \\
\hline VE & MO & PMe & C & 11,8 & 5,3 & 12,7 & 10,2 & 3,6 & 5,0 & 12,6 & 9,4 & 14,0 & 4,4 & 3,6 & 4,5 & 8,8 \\
\hline VE & MO & PMe & $S$ & 8,9 & 7,8 & 16,4 & 5,1 & 2,5 & 3,1 & 16,0 & 9,8 & 9,4 & 12,5 & 1,8 & 1,7 & 2,2 \\
\hline VE & MO & PMa & C & 5,7 & 4,1 & 16,5 & 10,2 & 3,0 & 1,2 & 14,3 & 9,5 & 12,4 & 10,5 & 12,5 & 3,5 & 4,0 \\
\hline VE & MO & PMa & S & 1,6 & 1,2 & 17,1 & 6,6 & 8,3 & 12,6 & 12,3 & 16,2 & 15,6 & 11,3 & 4,1 & 7,2 & 4,3 \\
\hline VE & MOPC & PMe & C & 5,2 & 2,8 & 9,3 & 12,1 & 5,5 & 11,6 & 11,9 & 13,9 & 12,4 & 12,5 & 6,2 & 0,4 & 1,9 \\
\hline VE & MOPC & PMe & $S$ & 5,6 & 9,4 & 11,7 & 7,6 & 10,5 & 10,9 & 14,7 & 10,6 & 10,6 & 12,3 & 13,2 & 3,5 & 4,3 \\
\hline VE & MOPC & PMa & C & 8,6 & 10,1 & 2,8 & 2,7 & 6,2 & 6,3 & 9,6 & 9,3 & 19,3 & 15,4 & 2,4 & 5,4 & 0,6 \\
\hline VE & MOPC & PMa & $S$ & 3,1 & 6,5 & 14,5 & 7,5 & 6,3 & 4,0 & 11,8 & 19,3 & 13,0 & 17,4 & 5,9 & 1,2 & 3,0 \\
\hline VE & PE & PMe & C & 2,1 & 3,9 & 12,2 & 1,6 & 14,6 & 17,1 & 12,1 & 3,5 & 11,6 & 15,6 & 0,9 & 2,5 & 2,9 \\
\hline VE & PE & PMe & $S$ & 5,5 & 11,7 & 16,5 & 2,1 & 8,2 & 7,5 & 9,9 & 12,3 & 13,2 & 16,4 & 7,2 & 3,3 & 2,9 \\
\hline VE & PE & PMa & C & 1,6 & 7,1 & 14,5 & 2,6 & 2,1 & 4,3 & 8,9 & 10,1 & 11,3 & 12,5 & 2,8 & 1,1 & 2,0 \\
\hline VE & $P E$ & $\mathrm{PMa}$ & $S$ & 1,2 & 4,0 & 17,4 & 9,0 & 3,1 & 11,1 & 17,3 & 0,8 & 9,5 & 11,5 & 10,9 & 0,3 & 7,2 \\
\hline
\end{tabular}

(IN - corte de inverno; VE - corte de verão; MO - silagem com a umidade original; MOPC - silagem com adição de polpa cítrica peletizada; PE - silagem pré emurchecida; PMa - partícula maior; PMe - partícula menor; C - com inoculante bacteriano; S - sem inoculante bacteriano; TMS - efeito da alteração no teor de matéria seca; PART - efeito do tamanho de partícula; INOC - efeito do inoculante bacteriano). 
Anexo I. Valores dos coeficientes de variação (CV, \%) dos parâmetros físicos e fermentativos, da silagem de capim Tanzânia.

\begin{tabular}{|c|c|c|c|c|c|c|c|c|c|c|c|c|c|}
\hline Época & TMS & PART & INOC & $\mathrm{pH}$ & $\overline{\mathrm{PT}}$ & NA & $\overline{C E}$ & Efluente & MS recup. & Gases & $\mathrm{EA}^{2}$ & Densidade $^{3}$ & Densidade $^{4}$ \\
\hline IN & $\mathrm{MO}$ & PMe & C & 2,6 & 14,3 & 4,1 & 2,8 & 12,0 & 1,3 & 18,6 & 3,6 & 4,8 & 9,5 \\
\hline IN & $\mathrm{MO}$ & PMe & $S$ & 2,7 & 5,2 & 4,9 & 4,4 & 9,8 & 2,5 & 21,3 & 2,7 & 2,3 & 6,6 \\
\hline IN & MO & PMa & C & 8,4 & 9,8 & 6,0 & 1,3 & 14,2 & 3,5 & 20,5 & 0,8 & 3,1 & 5,6 \\
\hline IN & $\mathrm{MO}$ & PMa & $S$ & 2,5 & 15,3 & 8,2 & 3,0 & 18,0 & 0,4 & 14,2 & 2,4 & 1,1 & 1,6 \\
\hline IN & MOPC & PMe & C & 2,8 & 15,9 & 6,3 & 4,3 & 14,6 & 0,5 & 12,4 & 2,9 & 3,1 & 6,2 \\
\hline IN & MOPC & PMe & $S$ & 3,3 & 13,7 & 8,9 & 5,8 & 17,5 & 0,8 & 21,1 & 4,1 & 0,8 & 6,1 \\
\hline IN & MOPC & PMa & C & 2,7 & 17,4 & 9,8 & 3,1 & 13,6 & 0,6 & 16,0 & 2,3 & 3,6 & 3,3 \\
\hline IN & MOPC & PMa & $S$ & 2,5 & 12,5 & 6,4 & 5,6 & 9,1 & 0,3 & 18,4 & 1,3 & 4,6 & 5,1 \\
\hline IN & PE & PMe & C & 1,2 & 12,3 & 7,8 & 3,1 & 8,7 & 2,3 & 21,9 & 1,3 & 2,8 & 3,2 \\
\hline IN & PE & PMe & $S$ & 3,7 & 14,6 & 7,0 & 3,7 & 15,2 & 3,1 & 17,2 & 2,1 & 3,1 & 5,3 \\
\hline IN & PE & PMa & C & 5,2 & 13,8 & 4,5 & 3,7 & 13,8 & 3,0 & 19,3 & 3,2 & 2,1 & 5,7 \\
\hline IN & PE & PMa & $S$ & 2,9 & 14,5 & 12,9 & 3,8 & 2,4 & 2,8 & 20,9 & 0,9 & 3,6 & 5,4 \\
\hline VE & $\mathrm{MO}$ & PMe & C & 1,2 & 16,0 & 12,6 & 6,7 & 12,3 & 11,4 & 20,3 & 2,2 & 4,5 & 8,6 \\
\hline VE & $\mathrm{MO}$ & PMe & $S$ & 1,7 & 12,6 & 10,3 & 4,8 & 8,0 & 8,3 & 5,8 & 2,3 & 2,9 & 10,1 \\
\hline VE & $\mathrm{MO}$ & PMa & C & 3,4 & 4,5 & 11,2 & 4,3 & 12,5 & 7,7 & 15,8 & 1,2 & 5,2 & 10,0 \\
\hline VE & $\mathrm{MO}$ & PMa & $S$ & 3,2 & 13,4 & 9,0 & 6,0 & 16,5 & 1,2 & 11,5 & 2,5 & 9,0 & 8,9 \\
\hline VE & MOPC & PMe & C & 1,6 & 8,8 & 9,1 & 1,5 & 13,8 & 3,7 & 22,6 & 2,9 & 6,2 & 10,9 \\
\hline VE & MOPC & PMe & $S$ & 1,0 & 5,4 & 8,8 & 2,7 & 9,8 & 5,8 & 14,1 & 2,1 & 1,9 & 6,5 \\
\hline VE & MOPC & PMa & C & 1,2 & 15,9 & 10,9 & 3,6 & 12,3 & 1,1 & 19,4 & 1,3 & 9,1 & 13,8 \\
\hline VE & MOPC & PMa & $S$ & 3,2 & 8,8 & 7,1 & 2,0 & 11,8 & 1,8 & 11,4 & 3,0 & 3,8 & 6,2 \\
\hline VE & PE & PMe & C & 2,1 & 10,5 & 6,2 & 2,0 & 13,4 & 2,2 & 17,7 & 1,6 & 3,2 & 2,9 \\
\hline VE & PE & PMe & $S$ & 3,6 & 13,7 & 9,5 & 2,4 & 13,1 & 4,2 & 20,1 & 0,9 & 2,9 & 6,3 \\
\hline VE & PE & PMa & C & 4,0 & 8,8 & 8,2 & 2,5 & 10,4 & 2,1 & 12,4 & 1,6 & 4,0 & 5,5 \\
\hline VE & PE & PMa & $S$ & 1,2 & 6,1 & 12,4 & 5,3 & 15,0 & 1,4 & 16,9 & 0,8 & 5,8 & 5,8 \\
\hline
\end{tabular}

${ }^{1}$ Matéria seca recuperada no silo experimental. ${ }^{2}$ Estabilidade aeróbica. ${ }^{3}$ Densidade (kg silagem. ${ }^{-3}$ ); ${ }^{4}$ Densidade (kg de MS silagem. $\left.\mathrm{m}^{3}\right)$. (IN - corte de inverno; VE - corte de verão; MO - silagem com a umidade original; MOPC - silagem com adição de polpa cítrica peletizada; PE - silagem pré emurchecida; PMa - partícula maior; PMe - partícula menor; C - com inoculante bacteriano; S - sem inoculante bacteriano; TMS - efeito da alteração no teor de matéria seca; PART - efeito do tamanho de partícula; INOC - efeito do inoculante bacteriano) 


\section{REFERÊNCIAS BIBLIOGRÁFICAS}

AGUIAR, R. N. S.; CRESTANA, R. F.; NUSSIO, L. G.et al. Efeito no tamanho de partícula na composição da fração nitrogenada de silagem de capim Tanzânia. In: REUNIÃO ANUAL DA SOCIEDADE BRASILEIRA DE ZOOTECNIA, 38., Piracicaba. Anais. Piracicaba: FEALQ, 2001. p.314-315.

ALBERTO, G.; PORTELLA, J.S.; OLIVEIRA, O.L.P. Effect of additional ground sorghum grain and of wilting on elephant grass. Grassland and Forage Abstract, v.65, n.2, p. 45-52, 1993.

ALLI, I.; THIFFAULT, C.; BAKER, B.E. A device for monitoring silage effluent produced in laboratory silos. Journal Dairy Science, v.68, p.3355-3359.

ANDRADE, I.F.; GOMIDE, J.A. Curva de crescimento e valor nutritivo do capim elefante (Pennisetum purpureum, Schum) cv. Taiwan A-146. Revista Ceres, v.18, n.100, p.431-447, 1971.

ANDRADE, J.B.; LAVEZZO, W. Aditivos na ensilagem do capim elefante. IV. Fermentação ruminal em ovinos. Pesquisa Agropecuária Brasileira, v.33, n.12, p.2025-2036, 1998.

ASHBELL, G.; WEINBERG, Z.G. Silage from tropical cereals and forage crops. IN: PROCEEDINGS OF THE FAO ELETRONIC CONFERENCE ON TROPICAL SILAGE, Rome, 1999. Silage making in the tropics with emphasis on smallholders: proceedings. Rome: FAO, 1999, p.109-115. 
ASSOCATION OF OFFICIAL AGRICULTURE CHEMISTS. Official methods of analysis. 12. ed. Washinton, D. C., 1990.

ATZEMA, A. J. A model for the drying of grass with real time weather data. Journal Agricultural Enginner Reaserch. v.53, p.231 - 247, 1992.

BALSALOBRE, M. A. A.; NUSSIO, L. G.; MARTHA Jr., G. B. Controle de Perdas na produção de Silagens de Gramineas Tropicais. Workshop Sobre Silagem. In: REUNIÃO ANUAL DA SOCIEDADE BRASILEIRA DE ZOOTECNIA, 38., Piracicaba, 2001. A produção animal na visão dos brasileiros. Piracicaba: FEALQ, 2001. p. 890-911.

BENACCHIO, S. Niveles de melaza en silo experimental de milho criollo (Sorghum vulgare). Agronomia Tropical, v.14, 4, p. 651- 658, 1965.

BERGAMASCHINE, A F.; ISEPON, O J.; GUATURA, A S.et al.. Efeitos da adição de resíduo de milho e da cultura enzimo-bacteriana sobre a qualidade da silagem de capim Tanzânia (Compact disc). In: REUNIÃO ANUAL DA SOCIEDADE BRASILEIRA DE ZOOTECNIA, 37., Viçosa. Anais. Viçosa: SBZ, 2000.

BERTO, J. L.; MUHLBACK, P. R. F. Silagem de aveia preta no estágio vegetativo, submetida a ação de inoculantes e efeito de emurchecimento. Revista da Sociedade Brasileira de Zootecnia, v.26, n.4, p.651-659, 1997.

BOLSEN, K.K.G.; ASHBELL, G; WILKINSON, P. Silage additives. In: CHESSON, A; WALLACE, R.J. Biotechnology in animal feeds and animal feeding. Weinhein: VCH Press, 1995. p.33-34. 
BUXTON, D.R.; FALES, S.L. Plant environment and quality. In: FAHAY, G. C. Jr.; COLLINS, M.; MERTENS, D.R.; MOSER, L.E.. Forage quality. Lincoln: ASA; CSSA \& SSSA; 1994. p.155-199.

CAI, Y.; UEGAKI, R.; FUJITA, Y. Lactic acid bacteria isolated from forage crops and silage fermentation. In: INTERNATIONAL GRASSLAND CONGRESS, 19., São Pedro, 2001. Proceedings. São Pedro: FEALQ, 2001, p.777-779.

CAO, L.M.; DEGUCHI, Y.; MIZUTANI, M.; GOTO, M.et al. Effects of preservation with pre-fermented green juice (FGJ) on fermentation quality and energy and nitrogen utilization of round-baled alfafa silage by dairy cattle. INTERNATIONAL GRASSLAND CONGRESS, 19., São Pedro, 2001. Proceedings. São Pedro: FEALQ, 2001. p.783 - 784.

CASTRO, F.G.; NUSSIO, L.G.; SIMAS, J.M.C. et al. Parâmetros físico-químicos da silagem de Tifton-85 (Cynodon sp) sob efeito do pré-emurchecimento e de inoculante bacteriano-enzimático. In: REUNIÃO ANUAL DA SOCIEDADE BRASILEIRA DE ZOOTECNIA. 38., Piracicaba, 2001. Anais. Piracicaba: FEALQ, 2001. p.270-272.

CHANEY, A L.; MARBACH, E.P. Modified reagents for determination of urea and amonia. Clinical Chemistry, v.8, p.130-137, 1962.

CHARMLEY, E.; SAVOIE, P.; MCQUEEN, R.E. Influence of maceration at cutting on lactic acid bacteria populations, silage fermentation and voluntary intake and digestibility of precision-chopped lucerne silage. Grass and Forage Science, v.52, p.110 - 121, 1997. 
CHARMLEY, E.; THOMAS, C. Wilting of herbage prior to ensiling: effects on conservation losses, silage fermentation and growth of beef cattle. Animal Production, v.45, p.191-203, 1987.

CLAVERO, T. Quality and nutritive value of Mott dwarf elephant grass with biological additives. In: INTERNATIONAL GRASSLAND CONGRESS, 19., São Pedro, 2001. Proceedings. São Pedro: FEALQ, 2001. p.770 - 771.

COAN, R.M.; VIEIRA, P.F.; SILVEIRA, R.N.et al. Efeito do inoculante enzimobacteriano sobre a composição química, digestibilidade e qualidade das silagens dos capins Tanzânia e Mombaça. In: REUNIÃO ANUAL DA SOCIEDADE BRASILEIRA DE ZOOTECNIA, 38., Piracicaba, 2001. Anais. Piracicaba: FEALQ, 2001. p.124-125.

CORRÊA, L.A., CORDEIRO, C.A. Silagem de capim como estratégia de manejo intensivo de pastagens. São Carlos: EMBRAPA, CPPSE, 2000. 6p. (Comunicado Técnico, 26).

CORSI, M.; SANTOS, P. Potencial de produção do Panicum maximum . In: SIMPÓSIO SOBRE MANEJO DA PASTAGEM. O CAPIM COLONIÃO, 12., Piracicaba 1995. Anais. Piracicaba: FEALQ, 1995. p.257-305.

CRestanA, R. F.; AGUIAR, R. N. S.; NUSSIO, L. G.et al. Efeito da fermentação na fração fibra de silagens de capim Tanzânia. In: REUNIÃO ANUAL DA SOCIEDADE BRASILEIRA DE ZOOTECNIA. 38., Piracicaba, 2001. Anais. Piracicaba: FEALQ, 2001. p.354-355. 
DAWSON, L.E.R.; FERRIS, C.P.; STEEN, R.W.J.et al. The effects of wilting grass before ensiling on silage intake. Grass and Forage Science, v.54, p.237-247, 1999.

DULPHY, J.P.; DEMARQUILLY, C. Influence de la machine de recolte et de la finesse de hachage sur la valeur alimentare des ensilages. Annales del Zootechnia, v. 12, n. 12, p.199-217, 1973.

ERWIN, W.S.; MARCO, G.J.; EMERY, E.M. Volatile fatty acid analyses of blood and rumen fluid by gas chromatography. Journal of Dairy Science, v.44, n.2, p.1768-1771, 1961.

EUCLIDES, V.P.B., MACEDO, M.C.M., VALLE, L.C.S., et al. Avaliação de acessos de Panicum maximum sob pastejo. Campo Grande: EMBRAPACNPGC, 1995. 7p. (EMBRAPA, Programa de Produção Animal. Subprojeto 06.0.94.172.04).

EUCLIDES, V.P.B.; MACEDO, M.C.M.; VIEIRA, A.et al. Evaluation of Panicum maximum cultivars under grazing. In: INTERNATIONAL GRASSLAND CONGRESS, 17., Palmerston North, 1993. Proceedings. Palmerston North: New Zealand Grassland Association, 1993. p.1999-2000.

EVANGELISTA, R.A; DE LIMA, J.A de; SIQUEIRA, R.G.et al. Aditivos na ensilagem de Coast cross (Cynodon dactylon (L.) Pers.) 1.Farelo de trigo e polpa cítrica. In: REUNIÃO ANUAL DA SOCIEDADE BRASILEIRA DE ZOOTECNIA. 38., Piracicaba, 2001. Anais. Piracicaba: FEALQ, 2001. p.71-72. 
EVANGELISTA, A R.; SILVA, L. V.; CORREIA, L. F. A . Efeito de três diferentes formas físicas de polpa cítrica, como aditivo seco na silagem de capim napier ( $P$. purpureum, Schum.). In REUNIÃO ANUAL DA SOCIEDADE BRASILEIRA DE ZOOTECNIA, 33., Fortaleza, 1996. Anais. Fortaleza: SBZ, 1996a . p. 352-353.

EVANGELISTA, A R.; SILVA, L. V.; CORREIA, L. F. A . Efeito de diferentes níveis de polpa cítrica, como aditivo seco na silagem de capim napier $(P$. purpureum, Schum.). In REUNIÃO ANUAL DA SOCIEDADE BRASILEIRA DE ZOOTECNIA, 33., Fortaleza,1996. Anais. Fortaleza: SBZ, 1996b. p.354-355.

de FARIA, V.P. Efeito da maturidade da planta e diferentes tratamentos sobre a ensilagem de capim elefante (Pennisetum purpureum, Schum) variedade Napier. Piracicaba, 1971. 78p. Tese (Doutorado). Escola Superior de Agricultura "Luiz de Queiroz", Universidade de São Paulo.

FILYA, I; ASHBELL, G.; HEN, Y.et al. The effects of bacterial inoculants on the fermentation and aerobic stability of wholecrop wheat silage. Animal Feed Science and Technology, v. 88, p.39-46, 2000.

FISHER, L.J.; ZURCHER, P.; SHELFORD, J.Aet al. Quantity and nutrient content of effluent losses from ensiled high moisture grass. Canadian Journal of Plant Science, v.61, p.307-312, 1981.

FITZGERALD, J.J. Grass silage as a basic feed for store lambs. 3. Effect of barley supplementation of silage varying in chop length on silage intake and lamb performance. Grass and Forage Science, v. 51, p.389-402, 1996. 
FRASER, M.D.; WINTERS, A.; FYCHAN, R.et al. The effect of harvest date and inoculation on the yield, fermentation characteristics and feeding value of kale silage. Grass and Forage Science, v.56, p.151-161, 2001.

FRANSEN, S.C.; STRUBI, F.J. Relationship among absorvents on the reduction of grass silage effluent and silage quality. Journal of Dairy Science, v. 81, p.2633-2644, 1998.

GALE, G.E.; KNIGHT, A. C. Apparatus and procedure for the accurate assessment of forage chop lenght. In: CONFERENCE ON FORAGE CONSERVATION IN THE $80^{\circ}$., London, 1979. Proceedings. London: British Grassland Society, 1979.p. 335-338.

GIGER-REVERDIN, S. Characterization of feedstffs for ruminants using some phisicalparameters. Animal Feed and Technology, v. 86, p. 53-69, 2000.

GORDON, F.J. Effect of silage additives and wilting on the animal performance. In: GARNSWORTHY, P.C. ; COLE, D.J.A (Ed.). Recents developments in ruminant nutrition. 3. ed. Nottingham: University Press, 1996. p.229-244.

GORDON, F.J.; DAWSON, L.E.R.; FERRIS, C.P.et al. The influence of wilting and forage additive type on the energy utilization of grass by growing cattle. Animal Feed Science and Technology, v.79, p.15-27, 1999.

GRENNHILL, W. L. Plant juice in relation to silage fermentation. Journal of the British Grassland Society, v.19, p.336-339, 1964. 
GRISE, M.M.; JOBIM, C. C.; CECATO, U.et al. Efeito do uso de inoculantes na composição química e $\mathrm{pH}$ da silagem de milheto ( $P$. americanum (L.) Leeke). In: REUNIÃO ANUAL DA SOCIEDADE BRASILEIRA DE ZOOTECNIA, 38., Piracicaba, 2001. Anais. Piracicaba: FEALQ, 2001. p.132-133.

HAIGH, P. M. Effluent production from grass treated with additives and made in large- scale bunker silos. Grass and Forage Science, v.54, p.208-218, 1999.

HENDERSON, N. Silage aditives. Animal Feed Science Technology Journal, v.45, p.35-56, 1993.

HOLDEN, L. A. Comparison of methods of in vitro dry matter for ten feeds. Journal of Dairy Science, v.82, n. 8, p.1791-1794, 1999.

HOLMES, B. J.; MUCK, R. E. Factors affecting bunker silo densities. Madison: University of Wisconsin, 1999, 7p.

HOVELAND, C. S.; MONSON, W.G. Genetic and eviromental effects on forage quality.. In: HOVELAND, C.S. Crop quality, storage and utilization. Madison: ASAE, CSSA, SSSA, 1994. cap. 11, p.450-493.

JACKSON, N.; FORBES, T.T. The voluntary intake by cattle of four silages differing in dry matter content. Animal Production, v.12, n.4, p.591-599, 1970. 
JANK, L. Potencial do gênero Panicum . In: SIMPÓSIO BRASILEIRO DE FORRAGEIRAS E PASTAGENS, Campinas, 1994. Anais. Campinas: SBNA, 1994. p.25-31.

JONES, D.I.H., JONES, R. The effect of crop caracteristcs and ensiling methodology on grass silage effluent production. Journal of Agricultural Enginneering Research, v. 60, p.73-81, 1995.

JONES, D.I.H., JONES, R. The effect of incorporating rolled barley in autumncut ryegrass on effluent production, silage fermentation and cattle performace. Journal of Agricultural Science, v.115, p.399-408, 1990.

KEADY, T.W.; O'KIELY, P. An evolution of the effects of rate of the nitrogen fertilisation of the grassland on silage fermentation, in silo losses, effluent production and stability. Grass and Forage Science, v 51, p. $350-362$, 1996.

KEADY, T.W.J.; STEEN, R.W.J. The effects of treating low dry-matter, low digestibility grass with a bacterial inoculant on the intake and performace of beef cattle, and studies on its mode action. Grass and Forage Science, v.50, p.217-226, 1995.

KEARNEY, P.C.; KENNEDY, W.K. Relationship between losses of fermentable suggars and changes of inorganics acids of silage. Agronomy Journal, v.54, n.2, p.114-115, 1962. 
KRAUS, T.J.; KOEGEL, R.G.; STRAUB, R.J.ET AL. Leachate conductivity as index for quantifying level of forage conditioning. In: ASAE ANUAL INTERNATIONAL METTING. Minneapolis, 1997. Proceedings. Minneapolis: ASAE, 1997. Paper 971100.

KRISHNAMOORTHY, U.C.; MUSCATO, T.V.; SNIFFEN, C.J.ET AL. Nitrogen fraction in selected feedstuffs. Journal of the Dairy Science, v.65, n.01, p.217, 1982.

KRISHNAMOORTHY, U.C.; SNIFFEN, C.J.; STERN, M.D.et al. Evaluation of a mathematical model of rumen digestion and in vitro simulation of rumen proteolysis to estimate the rumen-undegraded nitrogen content of feedstuffs. Bristish Journal of Nutrition, v.50, p.555-568, 1983.

KUNG, Jr. Microbial and chemical additives for silage - Effects on fermentation and animal response. In: WORKSHOP SOBRE MILHO PARA SILAGEM, 2.,Piracicaba, 2000. Anais. Piracicaba: FEALQ. 2000 (no prelo).

LAMMERS, B.P., BUCKMASTER, D.R.; HEINRICHS, E. J. A simple method for the analysis of particle sizes of forage and total mixed rations. Journal of Dairy Science, v.79, n.5, p.922-928, 1996.

LAVEZZO, W. Silagem de capim elefante. Informe Agropecuário, v.11, p.132, 1985.

LAVEZZO, W. Ensilagem de capim elefante. In: SIMPÓSIO SOBRE MANEJO DE PASTAGEM, 10., Piracicaba, 1993. Anais. Piracicaba: FEALQ, 1993. p.169-275. 
LEVITT, J. Responses of the plants to environmental stress. New York: Academic Press. 1980. 324p.

LOURES, D.R.S. Características do efluente e composição químicobromatológica da silagem sob níveis de compactação e de umidade do capim-elefante (Pennisetum purpureum Schum.) cv. Cameroon. Viçosa, 2000. Dissertação (Mestrado). Universidade Federal de Viçosa.

MACHADO FILHO, L.C.P.; MUHLBACH, P.R.F. Efeito do emurchecimento na qualidade das silagens de capim elefante cv Cameroon (Pennisetum purpureum, Schum) e de milheto (Pennisetum americanum (L.) Leeke), avaliadas quimicamente. Revista da Sociedade Brasileira de Zootecnia, v.15, n.3, p.224-233, 1986.

McCULLOUGH, M.E. Silage and silage fermentation. Feedstuffs, v.49, n.13, p.49-50, 1977.

McDONALD, P.; HENDERSON, A.R. The biochemistry of silage. New York: John Wiley, 226p., 1981.

McDONALD, P.; HENDERSON, A.R.; HERON, S.J.E. In: The biochemistry of silage 2. Ed. Marlow: Chalcombe Publications, 1991. 226 p.

McGECHAN, M.B.; COOPER, G.; KNIGHT, A.C.et al. An assessment of macerating mowers for zero effluent production. Journal of Agricultural Enginnering Research. v.75, p.291-313, 2000.

MERTENS, D.R. Regulation of forage intake. In: FAHEY Jr., G. C. (Ed.). Forage quality, evolution and utilization. Madinson: ASA, SSSA, 1994. cap.11, p.450-453. 
MICHELENA, J.B.; MOLINA, A. The effect of time of sun exposure of kinggrass (Hybrid Pennisetum) on silage quality. Cuban Journal of Agricultural Science, v.24, n. 2, p.219-224, 1990.

MORAIS, J.P.G. Silagem de gramíneas tropicais. In: SIMPÓSIO SOBRE NUTRIÇÃO DE BOVINOS, 7., Piracicaba, 1999. Anais. Piracicaba: FEALQ, 1999. p. $89-95$.

MOSER, L.E. Post-harvest physiological changes in forage plants. In: MOORE, J.K.; KRAL, D.M.; VINEY, M.K (Ed.) Post-harvest physiology and preservation of forages. Madison: Crop Science Society of Agronomy and American Society of Agronomy, 1995. p.1-19.

MUCK, R.; KUNG Jr., L. Effects of silage additives on ensiling. In: SILAGE: FIELD TO FEEDBUNK. NRAES-99, Herchey, 1997. Proceedings. Herchey: NRAES, 1997. p.187-199.

MUCK, R.E. Effect of inoculation level on alfafa silage quality. Transactions of the ASAE, v.32, p.1153-1158, 1989.

MUCK, R.E. The role of silage additives in making high quality silage In: NATIONAL SILAGE PRODUCTION CONFERENCE. NRAES-67, NRAES, Ithaca, N.Y., USA, 1993. Proceedings. Ithaca: NRAES, 1993. p.106-116.

MUHLBACH, P.R.F. Additives to improve the silage making process with tropical forages. IN: PROCEEDINGS OF THE FAO ELETRONIC CONFERENCE ON TROPICAL SILAGE, Rome, 1999. Silage making in the tropics with emphasis on smallholders: Proceedings. Rome: FAO, 1999. p. $151-164$. 
NARCISO SOBRINHO, J. Silagem de capim Elefante (Pennisetum purpureum Schum.), em três estádios de maturidade, submetido ao emurchecimento. Piracicaba, 1998. 105p. Dissertação (Mestrado) - Escola Superior de Agronomia “Luiz de Queiroz”, Universidade de São Paulo.

NATIONAL RESEARCH COUNCIL. Nutrient requirements of dairy cattle. 7.ed. Washington, 2001.

NIIMI, M.; KAWAMURA, O. Fermentation and cell wall degradation in guineagrass and italian ryegrass silages. In: INTERNATIONAL GRASSLAND CONGRESS, 19., São Pedro, 2001. Proceedings. São Pedro: FEALQ, 2001. p.773-775.

NUSSIO, L.G.; MANZANO, R.P.; PEDREIRA, C.G.S. Valor alimentício em plantas do gênero cynodon. In: SIMPÓSIO SOBRE MANEJO DE PASTAGENS. MANEJO DE TIFTON, COASTCROSS E ESTRELA. 15., Piraciaba, 1998. Anais. Piracicaba: FEALQ, 1998. p. 242-245.

NUSSIO, L. G.; MANZANO, R. P.; AGUIAR, R. N. S.et al. Silagem do excedente de produção das pastagens para suplementação na seca. SIMPÓSIO SOBRE MANEJO E NUTRIÇÃO DE GADO DE CORTE, 1, Goiania, 2000. Anais. Goiania: CBNA, 2000. p.121-138.

NUSSIO, L.G.; CASTRO, F.G.; SIMAS, J.M.;. Effects of dry matter content and microbial additive on Tiffton 85 (Cynodon dactylon ssp) wilted silage fermentation parameters. In: INTERNATIONAL GRASSLAND CONGRESS, 19., São Pedro 2001. Proceedings. São Pedro: FEALQ, 2001. p.790 - 792. 
O'KIELY, P.; MOLONEY, A.; KEATING, T.et al. Maximing output of beef within cost efficient, environmental compatible forage conservation systems. Dunsany: Teagast, 1999. cap.3, p.31-43.

O'DONNELL, C.O.; WILLIAMS, A.G.; BIDDLESTONE, A.J. The effect of pressure and stage of ensilage on the mechanical properties and effluents production potential of grass silage. Grass and Forage Science, v.52, p.1256, 1997.

OUDE ELFERINK, S.J.W.H.; DRIEHUIS, F.; GOTTSCHAL, J.C.; SPOELSTRA, S.F. IN: PROCEEDINGS OF THE FAO ELETRONIC CONFERENCE ON TROPICAL SILAGE, Rome, 1999. Silage making in the tropics with emphasis on smallholders: Proceedings. Rome: FAO, 1999. p.17-30.

PAULY, T. M. Heterogeneity and hygienic quality of grass silage. uppsala, 1999. 1v. Dissertation (Doctoral). Swedish Univrsity of Agricultural Sciences.

PLAYNE, M.J., McDONLAD, P. The buffering constituents of herbage and of silage. Journal of Science Food Agriculture, v.17, n. 6, p.264-268, 1966.

PEDREIRA, J.V.S. Crescimento estacional dos capins colonião (Panicum maximum, Jacq.), gordura (Melinis minutiflora Pal. de Beauv), jaraguá (Hyparrhenia rufa(ness) Stapf) e pangola (Digitaria pentzii, Stent). Piracicaba, 1972. Tese (Doutorado). Escola Superior de Agricultura "Luiz de Queiroz", Universidade de São Paulo. 
PEDREIRA, M.S.; MOREIRA, A L.; REIS, R. Aet al. Características químicas e fermentativas do Tifton 85 (Cynodon ssp.) ensilado com diferentes conteúdo de matéria seca e níveis de polpa cítrica. In: REUNIÃO ANUAL DA SOCIEDADE BRASILEIRA DE ZOOTECNIA. 38., Piracicaba, 2001. Anais. Piracicaba: FEALQ, 2001. p.100-102.

PERES, J.R. Avaliação da polpa de citros seca e peletizada como aditivo na ensilagem de capim elefante (Pennisetum purpureum, Schum). Piracicaba, 1997. 82 p. Dissertação (Mestrado). Escola Superior de Agricultura "Luiz de Queiroz", Universidade de São Paulo.

PITT, R. E. Modeling the efects of propionic acid bacteria in silage. Transactions of the ASAE, v.40, n.2, p.405-411, 1997.

PRÓSPERO, A.O. Variação estacional da composição química-bromatológica, do teor de macronutrientes minerais e da digestibilidade "in vitro" do capim elefante (Pennisetum purpureum, Schum) variedade Napier. Anais da Escola Superior de Agricultura "Luiz de Queiroz", 29, p.81-93. 1972.

RAMMER, C. Manure in grass silage production. Uppsala, 1996. $1 \mathrm{v}$. Dissertation (Doctoral) - Swedish University of Agricultural Sciences

RAMMER, C.; SLOTTNER, D. Ensiling of different legumes compared to grass. INTERNATIONAL GRASSLAND CONGRESS, 19., São Pedro, 2001. Proceedings. São Pedro: FEALQ, 2001. p.776-777.

RANJIT, N.K.; KUNG Jr., L. The effects of lactobacillus buchneri, lactobacillus plantarum, or a chemical preservative on the fermentation and aerobic stability of corn silage. Journal of Dairy Science, v.83, n.3, p.526-535, 2000. 
REYNOLDS, A.M.; WILLIAMS, A.G. A model of silage consolidation and effluent flow. Journal Agricultural Enginnering Research. v.61, p.173-182, 1995.

REIS, R.A ; RODRIGUES, L. R. Aditivos para produção de feno. In: REUNIÃO DA SOCIEDADE BRAZILEIRA DE ZOOTECNIA, 34., Botucatu, 1998. Anais. Botucatu: Sociedade Brazileira de Zootecnia, 1998. p.109-152.

ROSE, A. H. Economic microbiology. Bath: Academic Press, 1983. Cap. 4, p.70-91: Reduced Water Activity.

ROTZ, C A; MUCK R. E. Changes in forage quality during harvest and storage. In:. FAHEY Jr., G. C. (ed.). Forage quality, evaluation, and utilization. Madison: ASA, CSSA, SSSA, 1994. p. 828-868.

SAS INSTITUTE. SAS: user's guide: statistics, version 5 edition. Cary, 1991.

SEGLAR, W.J. Dairy production management: silage management. 1997. http:// www.pioneer.com/xweb/usa/txtrestech/nutrition/dpm.htm (12 dez. 1997).

SHARP, HOOPER, P.G., ARMSTRONG, D.G. The digestion of grass silage produced using inoculants of lactic acid bacteria. Grass and Forage Science, v.49, n.1, p.42-53, 1994.

SHINNERS, K. J.;JIROVEC, A.G.;SHAVER, R.D. et al. Processing wilted alfafa with crop processing rolls on a pull-type forage harvester. Applied Engineering in Agriculture, v.4, p.333-340.

SILVEIRA, A.C. Técnicas para a produção de silagens. In: SIMPÓSIO SOBRE MANEJO DE PASTAGEM, 2. , Piracicaba, 1975. Anais. Piracicaba: ESALQ, 1975. p.156-186. 
SILVEIRA, A.C.; FARIA, V.P. de, TOSI, H. Efeito da maturidade sobre o valor nutritivo do capim Napier. O Solo, v.65, n.2, p.35-41, 1973a.

SILVEIRA, A. C.; LAVEZZO, W.; SILVEIRA, F.S. Consumo de silagem de capim Elefante (Pennisetum purpureum Schum.), submetida a diferentes tratamentos. Revista da Sociedade Brasileira de Zootecnia, v.9, n.2, p.306-320, 1980.

SILVEIRA, A.C., TOSI, H.; FARIA, V.P de. Efeito de diferentes tratamentos na digestibilidade "in vitro" de silagem de capim napier (Pennisetum purpureum, Schum). Revista da Sociedade Brasileira de Zootecnia, v.2, n.2, p.216-226, 1973b.

SNIFFEN, C.J.; O'CONNOR, J.D.; VAN SOEST, P.J.et al. A net carbohydrate and protein system for evaluating cattle diets: II. Carbohydrate and protein availability. Journal of Animal Science, v.70, p.3562-3577, 1992.

SNIJDERS, P.J.M.; WOUTERS, A .P. Silage e quality and losses associated with ensiling of napier grass, columbs grass and maize stover under smallholder conditions in kenya. IN: PROCEEDINGS OF THE FAO ELETRONIC CONFERENCE ON TROPICAL SILAGE, Rome, 1999. Silage making in the tropics with emphasis on smallholders: Proceedings. Rome: FAO, 1999. p. 55 - 57.

THOMAS, C.; THOMAS, P.C. Factors affecting the nutritive value of grass silages. In: COLE, D. J.; HARESING, W (ed.) Recent advances in animal nutrition. London: Butterworths, 1985. p. 223-256. 
TOSI, H., BONASSI, I.A., ITURRINO, R.P.S., et al. A. Avaliação química e microbiológica da silagem de capim elefante, cultivar Taiwan A-148, preparada com bagaço de cana de açúcar. Pesquisa Agropecuária Brasileira, v. 24, n.11, p.1313-1317, 1989.

TOSI, P.; MATTOS, W.R.S.; TOSI, H. et al. Avaliação do Capim Elefante (Pennisetum purpureum Schum.) Cultivar Taiwan A-148, ensilado com diferentes técnicas de redução de umidade. Revista da Sociedade Brasileira de Zootecnia, v.28, n.5, p.947-954, 1999.

VAN SOEST, P.J.; ROBERTSON; J.B.; LEWIS, E.B.A. Methods for dietary fiber, neutral detergent fiber, and nonstarch polysaccharides in relation to animal nutrition. Journal of Dairy Science, v.74, n.10, p.3583-3589, 1991.

VAN SOEST, P. J. Nutricional ecology of the ruminants. 2.ed. New York: Cornell University, 1994. p.140-155.

VEIGA, K.Z.; TERZIAN, M.C.; NUSSIO, L.G.et al. Efeito do tamanho de partícula, adição de polpa cítrica e inoculante bacteriano em silagem de capim Tanzânia (Panicum maximum Jacq.) (compact disc). In: SIMPÓSIO INTERNACIONAL DE INICIAÇÃO CIENTÍFICA DA UNIVERSIDADE DE SÃO PAULO, 8., 2000. São Paulo: USP, 2000.

VILELA, H.; BARBOSA, F.A; DIAS, E.T. et al. Qualidade das silagens de capim elafante paraíso (Pennisetum hybridum cv. Paraiso) submetidos a três tempos de emurchecimento. In: REUNIÃO ANUAL DA SOCIEDADE BRASILEIRA DE ZOOTECNIA. 38., Piracicaba, 2001. Anais. Piracicaba: FEALQ, 2001. p.323- 324. 
VILELA, D. Aditivos para silagem. In: Aditivos para silagem de plantas de clima tropical. In: REUNIÃO ANUAL DA SOCIEDADE BRASILEIRA DE ZOOTECNIA, 35., Boutcatu, 1998. Anais. Botucatu: SBZ, 1998. p.73-108.

WEINBERG, Z. G.; MUCK, R. New trends and opportunities in the development and use of inoculants of silage. Microbiology Reviews, v. 19, p. $53-68$, 1996.

WIERINGA, G.W. Some factors affecting silage fermentation. In: INTERNATIONAL GRASSLAND CONGRESS, Berkshire, 1960. Proceedings. Berkshire, 1960. p.497-502.

WEISS, B. When consider silage additives. In:TRI STATE DAIRY NUTRITION CONFERENCE, Forte Wayne, 1996. Proceedings. p.125-138.

WEISSBACH, F., SCHMIDT, L., HEIN, E. Method of anticipation of tha run of fermentation in silage making, based on the chemical composition of green fodder. In: INTERNATIONAL GRASSLAND CONGRESS, 12., Moscow, 1974. Proceedings. Moscow, 1974. p. 663-673.

WILSON, J. R. Environment and nutritional factors affecting herbage quality. In; HACKER J.B. (Ed.). Nutricional limits to animal production from pastures. Farnham: CAB. 1982. p. 111-131.

WILES. P.G.; GRAY, I.K.; KISSLING, R.C. Routine analysis of protein by Kjeldahl nd Dumas methods:: rewiew and interlaboratory study using dairy products. Journal of AOAC International, v.81, n.3, p.620-632, 1998. 
WINTERS, A. L.; FYCHAN, R.; JONES, R. Effect of formic acid and bacterial inoculant on the amino acid composition of grass silage and animal performance. Grass and Forage Science, v.56, p.181-192, 2001.

WOOLFORD, M.K. The silage fermentation. New York: Marcel Dekker, 1984. $350 \mathrm{p}$.

WRIGHT, D. A; GORDON, F.J.; STEEN, R.W.J.et al. Factors influencing the response in intake of silage and animal performance after wilting of grass before ensiling: a review. Grass and Forage Science, v.55, p.1-13, 2000.

YAHAYA, M.S.; KIMURA, A.; HARAI, J.et al. Effect of length of ensiling on silo degradation and digestibility of structural carbohidrates of lucerne and orchardgrass. Animal Feed Science and Technology, v. 92, p.141-148, 2001.

YAN, T.; PATTERSON, D.C.; GORDON, F.J. et al. Effects of bacterial inoculation of unwiletd and wilted grass silage. 1. Rumen microbial activity, silage nutrient degradability and digestibility. Journal of Agricultural Science, v.131, p.103-112, 1998.

ZIERENBERG, B.; FRIEDEL, K.; GLATZLE, Aet al. Assessment of ensilability of six tropical grasses using three different approaches. INTERNATIONAL GRASSLAND CONGRESS, 19., São Pedro, 2001, Proceedings. São Pedro: FEALQ, 2001. p.786 - 788. 